\title{
Land Use, Organochlorine Compound Concentrations, and Trends in Benthic-Invertebrate Communities in Selected Stream Basins in Chester County, Pennsylvania
}

By Mark A. Hardy, Kim L. Wetzel, and Craig R. Moore

U.S. GEOLOGICAL SURVEY

Water-Resources Investigations Report 94-4060

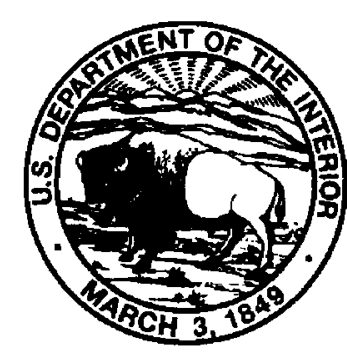




\title{
U.S. DEPARTMENT OF THE INTERIOR \\ BRUCE BABBITT, Secretary
}

\author{
U.S. GEOLOGICAL SURVEY \\ Gordon P. Eaton, Director
}

For additional information write to:

District Chief

U.S. Geological Survey

840 Market Street

Lemoyne, Pennsylvania 17043-1586
Copies of this report may be purchased from:

U.S. Geological Survey

Earth Science Information Center

Open-File Reports Section

Box 25286, MS 517

Denver Federal Center

Denver, Colorado 80225 


\section{CONTENTS}

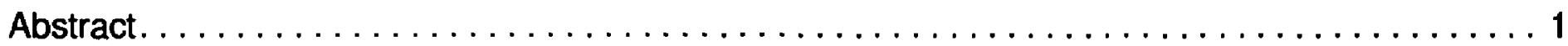

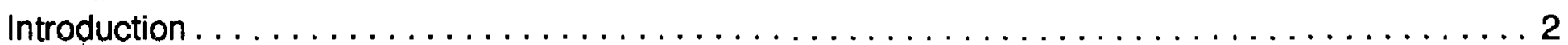

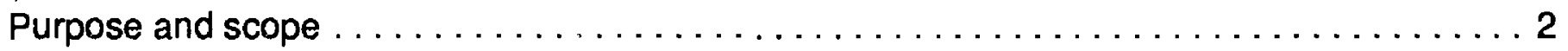

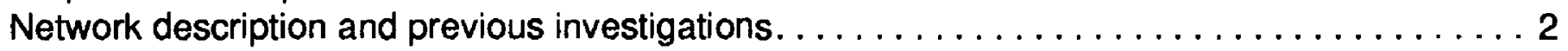

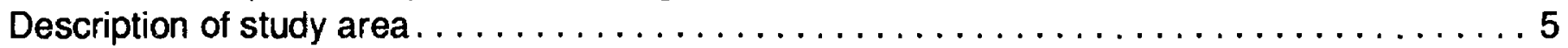

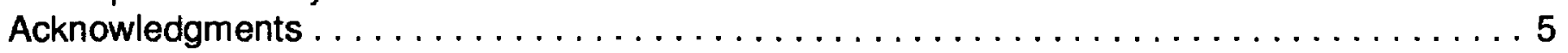

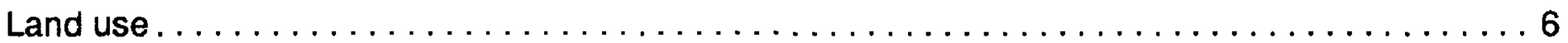

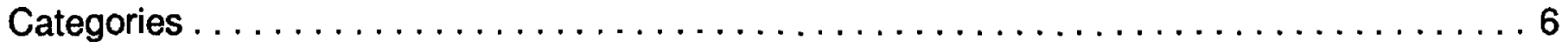

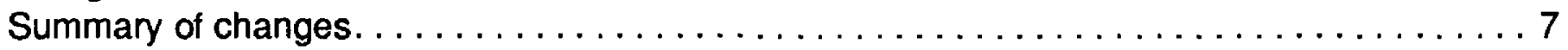

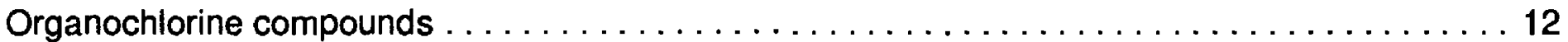

Icedale Lake sediment cores............................... 12

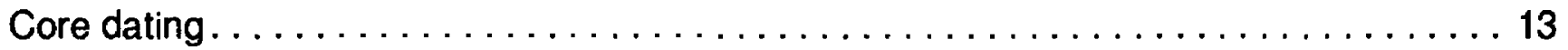

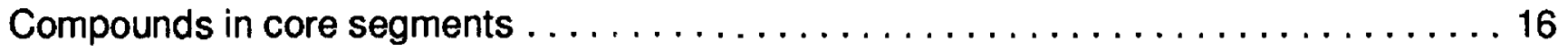

Stream-bottom materials . . . . . . . . . . . . . . . . . . . . . . . . . 16

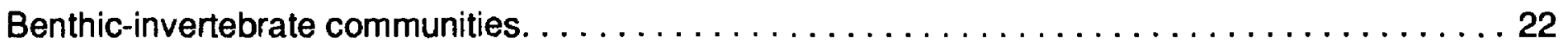

Relations among land use, benthic-invertebrate communities, and organochlorine compounds $\ldots 24$

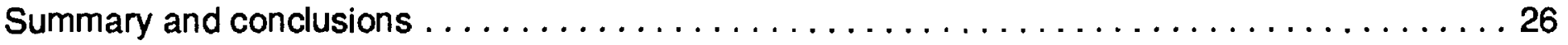

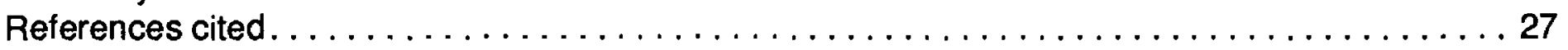

Appendix: Brillouin's diversity index, maximum diversity, minimum diversity, and relative evenness, by site. . . . . . . . . . . . . . . . . . . . . . . . . . . 29

\section{ILLUSTRATIONS}

Figure 1. Map showing location of sampling sites in Chester County, Pa. .............

2-4. Graphs showing:

2. Relation between annual peak flows and annual sediment discharge at

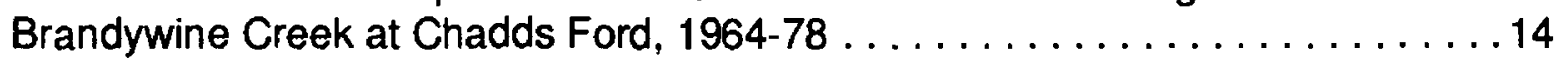

3. Depth profile of ratio of cesium-137 and silt-clay fraction in bottom materials

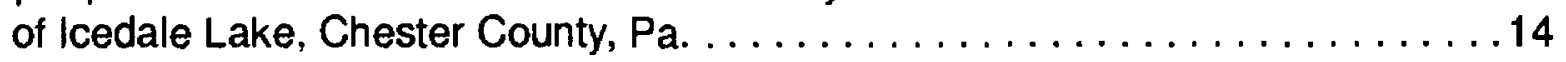

4. Depth profiles of ratios of selected organochlorine compounds and organic carbon in bottom materials of Icedale Lake, Chester County, Pennsylvania . . . . 17 


\section{CONTENTS-Continued}

\section{TABLES}

Table 1. Drainage areas of sampling sites for major streams in Chester County, Pennsylvania . . .4

2. Changes in land use within drainage areas of selected stream sites in Chester County, Pa., 1967-87 . . . . . . . . . . . . . . . . . . . . . . . . . . . . . . . 7

3. Change in land use for Icedale Lake Basin, Chester County, Pa., 1967-87 . . . . . . 12

4. Concentrations of carbon and organochlorine compounds, Cesium-137 activities, and silt and clay sized particles in bottom materials at selected depths from icedale Lake, Chester County, Pa., September 1988 . .

5. Concentrations of organochlorine compounds on unsorted streambed materials in Chester County, Pennsylvania, October 1985 through November 1987 . . . . . . . . 18

6. Concentrations of organochlorine compounds exceeding or equalling $\mathbf{1 5}$ micrograms per kilogram on unsorted streambed materials in Chester County, Pa., October 1985 through November 1987

7. Comparison of pesticide concentrations at paired sites with increasing residential

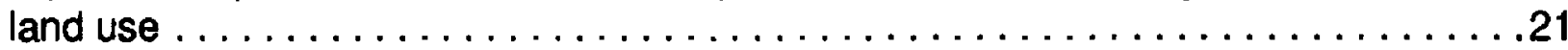

8. Values of slope, tau, $p$, and level of confidence from seasonal Kendall test of diversity index. . . . . . . . . . . . . . . . . . . . . . . . . . . .

\section{CONVERSION FACTORS AND ABBREVIATED WATER-QUALITY UNITS}

Multiply

inch (in.)

square mile $\left(\mathrm{mi}^{2}\right)$

cubic foot per second $\left(\mathrm{ft}^{3} / \mathrm{s}\right)$
By

2.590

0.02832
To obtain

centimeter square kilometer cubic meter per second

Abbreviated water-quality units used in this report

micrometer $(\mu \mathrm{m})$

micrograms per kilogram $(\mu \mathrm{g} / \mathrm{kg})$

picocurie per gram $(\mathrm{pCi} / \mathrm{g})$

grams per kilogram $(\mathrm{g} / \mathrm{kg})$ 


\title{
LAND USE, ORGANOCHLORINE COMPOUND CONCENTRATIONS, AND TRENDS IN BENTHIC-INVERTEBRATE COMMUNITIES IN SELECTED STREAM BASINS IN CHESTER COUNTY, PENNSYLVANIA
}

\author{
By Mark A. Hardy, Kim L. Wetzel, and Craig R. Moore
}

\begin{abstract}
Land use was analyzed for the drainage areas of 26 stream sites in Chester County, $\mathrm{Pa}$., that cover a total area of 227 square miles or about 30 percent of the county. The most significant land-use changes during 1967-87 were decreased agricultural land use, increased residential land use, and increased commercial and industrial land use.

Bulk samples of stream-bottom materials were collected at 42 sites in the study area from October 1985 through November 1987 and analyzed for content of organochlorine pesticides and polychlorinated biphenyls (PCB's). Organochlorine compounds and (or) PCB's were detected in streambed materials collected at 40 of the 42 sites sampled. The most enriched compounds (greater than 15 micrograms per kilogram) were PCB's, chlordane, and DDT plus its breakdown products. Data suggest that chlordane residues are closely associated with residential land use. PCB residues are closely associated with industrial and commercial land use.

Cores of lakebed sediments from the site of Icedale Lake, a drained reservoir on the West Branch Brandywine Creek, indicate that DDT was the first organochlorine pesticide to enter the Brandywine Creek; concentrations peaked in the late 1940's and early 1950's. As DDT influx subsequently decreased, influxes of chlordane and dieldrin increased and peaked in the mid-1960's, before the Chester County biological monitoring program. Influx of all pesticides appears to have decreased significantly since the 1960's.

Upward trends in Brillouin's diversity index for benthic-invertebrate communities were found at 45 of 46 stream sites in Chester County. The upward trends were statistically significant at the 99-percent confidence level at 30 sites. Trends at only four sites were not statistically significant at the 90-percent confidence level.

Contingency analyses showed that the relation between the Kendall slope estimator for trend and the increases in residential land use of 12 percent or greater were significant at the 95-percent confidence level. The contingency tables also showed that the relation between diversity indices of less than 2.25 and organochlorine-compound concentrations greater than 45 micrograms per kilogram was significant at the 95-percent confidence level.
\end{abstract}




\section{INTRODUCTION}

Chester County, in southeastern Pennsylvania, is being rapidly urbanized. Former agricultural land is being converted to residential developments, commercial areas, and industrial and corporate parks. This urban growth is affecting the quality of streams in Chester County. A study by Moore (1987) showed that the diversity of benthic-invertebrate communities increased at 44 of 46 sites and decreased at 2 sites from 1970-80. Subsequent sampling of stream-bottom sediments at one of the two sites where the diversity decreased revealed elevated concentrations of pesticides and other organic compounds. A study by Sloto (1987) showed that the more rapidly a basin in eastern Chester County changed from rural to suburban, the faster the diversity index increased. Both studies suggest that changes in diversity may be related to organochlorine compounds in stream-bottom sediment, and that this relation also can be affected by land use.

Information is needed to improve the understanding of the relations among land use and changes in land use, organochlorine-compound concentrations, and benthic-invertebrate diversity indexes so that Chester County planners and developers can maintain improvements in diversity index already observed (Moore, 1987). In 1988, a study to obtain such information was begun by the U.S. Geological Survey (USGS) in cooperation with the Chester County Water Resources Authority (CCWRA).

\section{Purpose and Scope}

This report describes (1) land-use changes in relation to the trends in diversity indexes of benthic-macroinvertebrate communities, (2) the detection and concentrations of organochlorine compounds in stream-bottom sediments in relation to diversity indexes, and (3) the distribution of organochlorine compounds in stream-bottom sediments at 42 stream sites in the study area.

The information in this report is based on data collected at 51 sites on 16 major streams in Chester County. The data record for 39 of these sites is continuous for 1970-88. Streambottom sediments were analyzed for organochlorine compounds during 1985-87 at 42 sites. Changes in land use from 26 drainage areas during 1967-87, obtained from the Chester County Planning Commission (CCPC), were quantified and compared to diversity trends at 26 stream sites in the county. Concentrations of organochlorine compounds were compared to diversity indexes of benthic-invertebrate samples collected at 42 stream sites in the county.

\section{Network Description and Previous Investigations}

In 1969, a limnological monitoring program began to evaluate water quality of selected Chester County streams by use of physical, chemical, and (beginning in 1970) benthicinvertebrate data. The program is a cooperative effort of the USGS, the CCWRA, and the Chester County Board of Commissioners. The project was conceived by Luna B. Leopold, former Chief Hydrologist, USGS, and Robert G. Struble, former Executive Director of the CCWRA. The major goal of the program is to further the understanding of stream changes in response to urbanization (Lium, 1977, p.6). Some changes have occurred since the creation of the network. Early analysis of the data resulted in discontinuance of nine sites (sites 7, 8,9, 11, $18,25,35,41$, and 43). At two sites (sites 16 and 39), quantitative data collection replaced qualitative collections after 1979. One new site (site 51) was added in 1983. The locations of the 51 sampling sites are shown in figure 1, and drainage areas are listed in table 1 . This network of sampling sites and the biological, physical, and chemical data collected for this program are the basis for this investigation. 


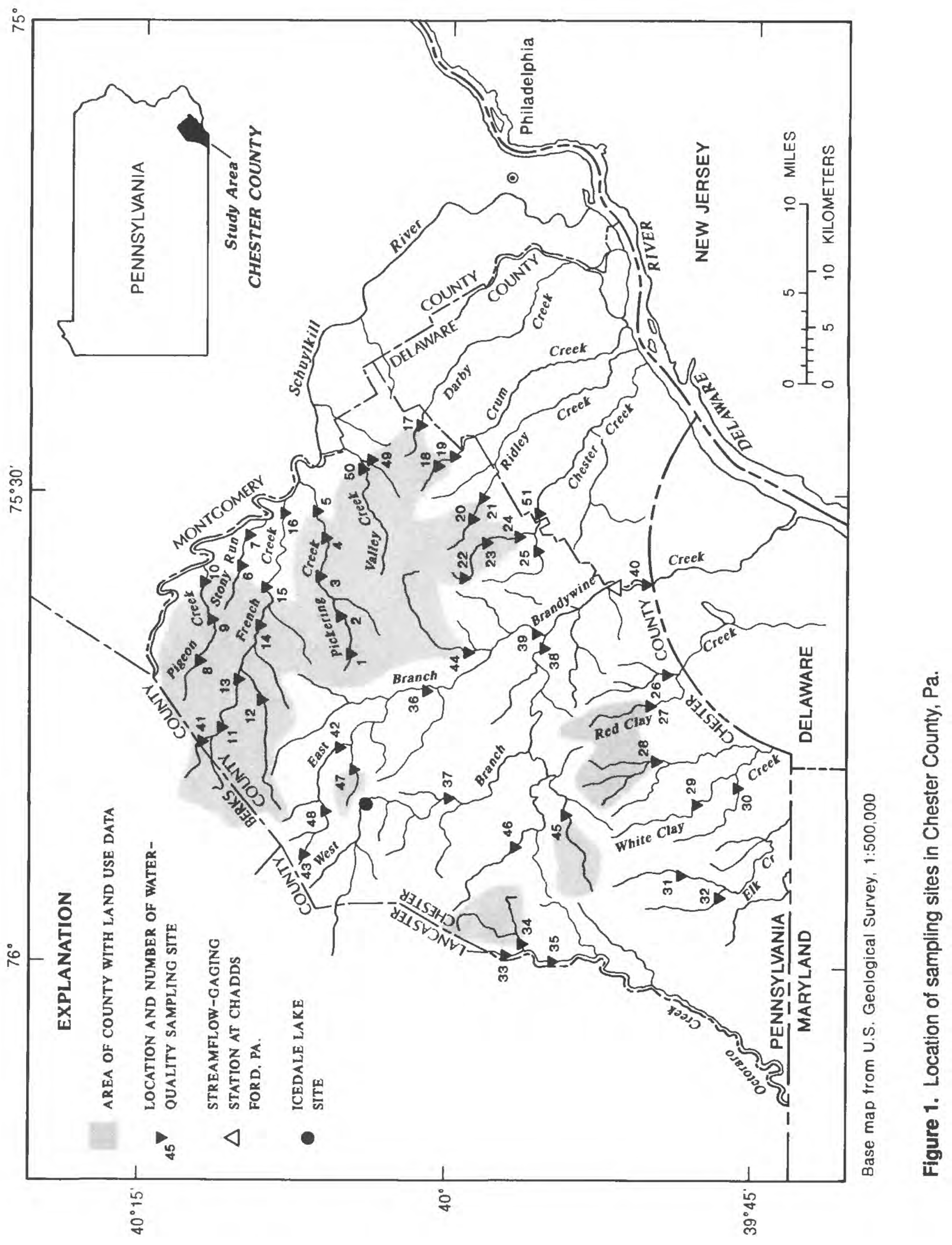


Table 1. Drainage areas of sampling sites for major streams in Chester County, Pennsylvania

[-, land-use data not available]

\begin{tabular}{|c|c|c|c|c|c|}
\hline $\begin{array}{c}\text { Site } \\
\text { number }\end{array}$ & $\begin{array}{l}\text { Drainage area } \\
\text { (square miles) }\end{array}$ & $\begin{array}{l}\text { Land-use data } \\
\text { available }\end{array}$ & $\begin{array}{c}\text { Site } \\
\text { number }\end{array}$ & $\begin{array}{l}\text { Drainage area } \\
\text { (square miles) }\end{array}$ & $\begin{array}{l}\text { Land-use data } \\
\text { available }\end{array}$ \\
\hline \multicolumn{3}{|c|}{ Pickering Creek } & \multicolumn{3}{|c|}{ Red Clay Creek } \\
\hline 1 & 3.09 & Yes & 26 & 10.2 & -- \\
\hline 2 & 5.98 & Yes & 27 & 9.79 & Yes \\
\hline 3 & 21.2 & Yes & \multicolumn{3}{|c|}{ White Clay Creek } \\
\hline 4 & 27.5 & Yes & 28 & 11.3 & Yes \\
\hline \multirow[t]{2}{*}{5} & 31.4 & Yes & 29 & 9.94 & -- \\
\hline & \multicolumn{2}{|l|}{ Stony Run } & 30 & 9.92 & -- \\
\hline 6 & 2.00 & Yes & \multicolumn{3}{|c|}{ Elk Creek } \\
\hline \multirow[t]{2}{*}{7} & 4.07 & - & 31 & 11.1 & -- \\
\hline & \multicolumn{2}{|c|}{ Pigeon Creek } & 32 & 10.0 & -- \\
\hline 8 & 4.20 & -- & \multicolumn{3}{|c|}{ Octoraro Creek } \\
\hline 9 & 6.97 & -- & 33 & 11.8 & -- \\
\hline \multirow[t]{2}{*}{10} & 12.0 & Yes & 34 & 10.5 & Yes \\
\hline & \multicolumn{2}{|c|}{ French Creek } & 35 & 32.9 & - \\
\hline 41 & 5.06 & -- & \multicolumn{3}{|c|}{ West Branch Brandywine Creek } \\
\hline 11 & 11.7 & -- & 37 & 37.3 & - \\
\hline 12 & 12.4 & Yes & 38 & 134. & -- \\
\hline 13 & 19.9 & Yes & 45 & 11.8 & Yes \\
\hline 14 & 46.1 & Yes & 46 & 22.6 & -- \\
\hline 15 & 59.1 & Yes & \multicolumn{3}{|c|}{ East Branch Brandywine Creek } \\
\hline \multirow[t]{2}{*}{16} & 70.7 & - & 36 & 60.6 & - \\
\hline & \multicolumn{2}{|c|}{ Darby Creek } & 39 & 123. & -- \\
\hline \multirow[t]{2}{*}{17} & 5.15 & Yes & 42 & 16.5 & -- \\
\hline & \multicolumn{2}{|c|}{ Crum Creek } & 43 & 4.36 & - \\
\hline 18 & 6.16 & -- & 44 & 16.1 & Yes \\
\hline \multirow[t]{2}{*}{19} & 10.1 & Yes & 47 & 4.26 & Yes \\
\hline & \multicolumn{2}{|c|}{ Bidley Creek } & 48 & 5.98 & - \\
\hline 20 & 4.22 & Yes & \multicolumn{3}{|c|}{ Brandrwine Creek } \\
\hline 21 & 9.71 & Yes & 40 & 291 & - \\
\hline \multicolumn{3}{|c|}{ Chester Creek } & \multicolumn{3}{|c|}{ Valley Creek } \\
\hline 22 & .63 & Yes & 49 & 6.45 & Yes \\
\hline 23 & 5.77 & Yes & 50 & 12.7 & Yes \\
\hline 24 & 10.4 & Yes & & & \\
\hline 25 & 4.28 & - & & & \\
\hline 51 & 19.2 & -- & & & \\
\hline
\end{tabular}

A report by Moore (1989) contains the physical, chemical, and biological data for this investigation for 1969-80. This superceded an earlier report by Lium (1976) that contained much of the same data for 1969-74. The physical and chemical data for the 1974-88 water years ${ }^{1}$ also have been published in the USGS annual water resources data reports for Pennsylvania (U.S. Geological Survey, 1975-89) and are available in USGS computer files.

Lium (1977) developed a biotic index that uses a 10-point rating scale to determine the environmental condition of streams at the 50 sites from his previous (1976) report. Most streams studied had ratings indicating they were experiencing variable degrees of nutrient enrichment and (or) sediment deposition. Large changes in the numerical rating of a stream were related to changes in land-use patterns.

${ }^{1}$ Water year is the 12-month period October 1 through September 30 and is designated by the calendar year in which it ends. 
In 1967-68, a study was conducted in the Pickering Creek and East Branch Brandywine Creek Basins by Miller and others (1971). Their study examined and documented existing hydrologic conditions in these two small basins so that the effects of future urbanization in the basins could be studied by comparison with their data. These two basins are among the areas studied in this investigation.

Moore (1987) evaluated the biological monitoring of stream-water quality in Chester County. This study showed statistically valid upward trends in Brillouin's diversity index during 1970-80 at 27 sites studied where improved environmental quality was indicated. However, few trends were detected in the physical and chemical data because of a high degree of variability in the data. Both Lium (1977) and Moore (1987) observed that total dissolved solids correlated significantly with biotic index and diversity index.

An investigation by Sloto (1987) described the effects of urbanization on water quality in eastern Chester County. Sloto observed that basins that had a greater change in land use, from undeveloped to developed, surprisingly had a greater increase in diversity index. Sloto postulated that the increase may be caused by the banning of certain pesticides, a decreasing use of pesticides in urbanizing basins, (and) or flushing or burial of older pesticidecontaminated sediments.

\section{Description of Study Area}

The study area is in the southeastern corner of Pennsylvania near Philadelphia (fig. 1) in the Piedmont Physiographic Province. General topography of the area is broad, gently rolling hills having low to moderate relief. Nearly 95 percent of Chester County $\left(720 \mathrm{mi}^{2}\right)$ is drained by the streams included in the study (fig 1). All streams sampled originate within the boundaries of the county, except for short reaches in the headwaters of the West Branch Brandywine, French, and Octoraro Creeks. Octoraro Creek forms part of the western boundary of the county, and its headwaters lie in both Chester and Lancaster Counties (fig. 1).

The population of Chester County doubled between 1950 and 1980 (Sloto, 1987) and increased another 10 percent from 1980 to 1987 to 348,484 persons. Population projections by the CCPC indicate that by the year 2010 , the county will have more than 418,000 persons (Chester' County Planning Commission, written commun., 1988).

Some areas, particularly in the eastern half of the county, have undergone more rapid growth. Several townships in the county have population increases ranging from 53 to 145 percent from 1970 to 1980 . These townships, along with six others in the county, are expected to increase 50 percent or more over their 1980 populations by the year 2010 (Chester County Planning Commission, written commun., 1988).

\section{Acknowledgments}

The cooperation of the Chester County Board of Commissioners, the Chester County Water Resources Authority, Chester County Planning Commission, and the Chester County Health Department is gratefully acknowledged. The authors are particularly indebted to Robert E. Walker and the staff of the Chester County Planning Commission for graciously allowing us to use their resources and facilities during the course of the study. Special thanks are extended to David C. Yaeck, former Executive Director of the Chester County Resources Authority, and Dr. Robin Vannote, Stroud Water Research Center, for their particular interest throughout the study. The authors also would like to thank all the individuals who provided assistance and information essential to the successful completion of this study. 


\section{LAND USE}

Drainage basins of 26 sites were selected for land-use analysis (table 1). These basins were selected to provide good areal coverage of Chester County and to represent the widest possible range of dominant land-use categories. Basins selected on French, Pickering, Ridley, and East Branch Chester Creeks comprise series of concatenated drainage areas representing progressively larger parts of the stream basin. These are referred to as "nested systems" in this report and allow observations of changing land use within individual watersheds. Land-use analyses were not performed for sites in the lower reaches of the Brandywine Creek Basin. These basins are quite large and heterogeneous, thus making it more difficult to separate the effects of differing land use. In addition, the lower Brandywine Creek Basin also contains many major point-source discharges that can mask the effects of land use in the basin.

\section{Categories}

Land-use classifications are from land-use maps prepared by the CCPC (1972; 1987). The seven land-use classifications used in this report are combinations with slight modifications of the 15 categories used by the CCPC.

Residential land use combines CCPC's Medium Density (single-family detached homes on lots less than 1 acre) and High Density (two-family dwellings, townhouses, apartments, and mobile homes) categories. For the purpose of this study, homes included in CCPC's Low Density residential category were placed in either the Open Space or Agricultural categories on the basis of the surrounding land use.

Commercial land use combines CCPC's Commercial, General (retail and wholesale trade, and professional, personal, and business services); Commercial, Office Park (office and corporate park development); and Institutional (health, educational, governmental, and religious facilities, excluding cemeteries, which were placed in the Open Space category).

Industrial land use combines CCPC's Industrial, Limited (light assembly, warehouse, and research and developmental facilities); Industrial, Manufacturing (processing, fabrication, or assembly of raw materials or component parts); Transportation/Communications/Utilities (rail, air, and highway transportation; communication facilities; and utility facilities); and Mining/Quarry (mining, quarrying, and other extractive operations).

Open space combines CCPC's Recreational Lands (parks, playgrounds, and related facilities, but excluding golf courses), Woodlands (tree masses in excess of 10 acres), Water Bodies (lakes and reservoirs in excess of 50 acres), Other Land (floodplain land, land which is awaiting development, vacant, unused, or otherwise undefined), and cemeteries. The woodlands are primarily composed of deciduous hardwoods such as red and black oak, tulip poplar, beech, sugar maple, and chestnut oak; and are situated on steep, less productive soils (Lium, 1977).

Agricultural lands were divided into three categories in CCPC's 1967 classification system: Agriculture (row crops), Pasture (pasture or meadow lands), and Specialized Agriculture (orchards, nurseries, tree farms, and mushroom farms). For the purpose of this study, the same categories for agricultural lands were used with one modification. Golf courses were included in the Specialized Agriculture category as opposed to Open Space (recreation land). Because of the heavy applications of fertilizers, insecticides, and herbicides, golf courses more closely approximate a specialized form of agriculture. Major crops are hay, winter wheat, corn, garden crops, and mushrooms. Livestock raised primarily include dairy and beef cattle, and horses. 


\section{Summary of Changes}

Land use was analyzed for the 26 drainage areas covering a total area of $227 \mathrm{mi}^{2}$ or about 30 percent of the county (table 2), Overall, the most significant land-use changes for these basins during 1967-87 were (1) decreased agricultural land use (ranging from 2.5 to 52.6 percent; median 14.2 percent); (2) increased residential land use (ranging from 4.0 to 42.9 percent; median 20.8 percent); and (3) increased commercial and industrial land use (ranging from 0 to 20.0 percent; median 3.0 percent). These changes were greatest in the northeastern half of the study area, including East Branch Brandywine Creek but excluding French and Darby Creeks.

Pasture and open space decreased in some basins and increased in others. Decreases for both categories generally were the result of residential, industrial, or commercial development. Increases in pasture seem to be a result of converted agricultural land use. Increases in open space seem to be a result of converted pasture and (or) agricultural land use.

The nested systems represented increases in residential land use ranging from 10.3 to 42.9 percent; and decreases in residential land use ranging from 5.0 to 34.8 percent. In the Pickering Creek and East Branch Chester Creek nested systems, land-use changes were not uniform. In Pickering Creek, the increase in residential land use was about 15 percent less for the site 1 drainage area than the other four downstream drainage areas. Agricultural land use progressively decreased by about 6 percent from the site 1 to the site 3 drainage areas. In East Branch Chester Creek, the increase in residential land use was about 13 percent greater for the site 24 drainage area (the most downstream site) than for the other two sites. The decrease in agricultural land use was about 11 percent less for the site 22 drainage area than for the other two downstream sites. In addition, open space increased 17 percent within this drainage area but decreased for the two downstream sites.

Table 2. Changes in land use within drainage areas of selected stream sites in Chester County, Pa., 1967-87

[Rounding may account for differences.]

\begin{tabular}{|c|c|c|c|c|c|c|}
\hline \multirow[b]{2}{*}{$\begin{array}{l}\text { Land-use } \\
\text { category }\end{array}$} & \multicolumn{2}{|c|}{1967} & \multicolumn{2}{|c|}{1987} & \multicolumn{2}{|c|}{ Change } \\
\hline & $\begin{array}{c}\text { Square } \\
\text { miles }\end{array}$ & $\begin{array}{c}\text { Percentage } \\
\text { of drainage } \\
\text { area }\end{array}$ & $\begin{array}{l}\text { Square } \\
\text { miles }\end{array}$ & $\begin{array}{c}\text { Percentage } \\
\text { of drainage } \\
\text { area }\end{array}$ & $\begin{array}{c}\text { Square } \\
\text { miles }\end{array}$ & $\begin{array}{c}\text { Percentage } \\
\text { of drainage } \\
\text { area }\end{array}$ \\
\hline \multicolumn{7}{|c|}{ Site 1} \\
\hline Open space & 0.80 & 25.8 & 0.67 & 21.7 & -0.13 & -4.2 \\
\hline Agricultural & 1.57 & 50.8 & 1.07 & 34.6 & -.50 & -16.2 \\
\hline Pasture & .58 & 18.8 & .67 & 21.7 & .09 & 2.9 \\
\hline Residential & .14 & 4.6 & .46 & 14.9 & .32 & 10.4 \\
\hline Commercial & .00 & .0 & .22 & 7.1 & .22 & 7.1 \\
\hline \multicolumn{7}{|c|}{ Site 2} \\
\hline Open space & 1.50 & 25.1 & 1.23 & 20.6 & -.27 & -4.5 \\
\hline Agricultural & 2.82 & 47.2 & 1.64 & 27.4 & -1.18 & -19.7 \\
\hline Pasture & 1.30 & 21.8 & 1.00 & 16.7 & -.30 & -5.0 \\
\hline Residential & .36 & 5.9 & 1.88 & 31.4 & 1.52 & 25.4 \\
\hline Commercial & .00 & .0 & .23 & 3.8 & .23 & 3.8 \\
\hline \multicolumn{7}{|c|}{ Site 3} \\
\hline Open space & 6.09 & 28.7 & 4.99 & 23.5 & -1.10 & -5.2 \\
\hline Agricultural & 9.47 & 44.7 & 4.78 & 22.6 & -4.69 & -22.1 \\
\hline Pasture & 4.83 & 22.8 & 4.10 & 19.3 & -.73 & -3.4 \\
\hline Specialized agriculture & .09 & .4 & .06 & .3 & -.03 & -.1 \\
\hline Residential & .60 & 2.8 & 6.23 & 29.4 & 5.63 & 26.6 \\
\hline Commercial & .00 & .0 & .23 & 1.1 & .23 & 1.1 \\
\hline Industrial & .12 & .6 & .81 & 3.8 & .69 & 3.3 \\
\hline
\end{tabular}


Table 2. Changes in land use within drainage areas of selected stream sites in Chester County, Pa., 1967-87-Continued

[Rounding may account for differences.]

\begin{tabular}{|c|c|c|c|c|c|c|}
\hline \multirow[b]{2}{*}{$\begin{array}{l}\text { Land-use } \\
\text { category }\end{array}$} & \multicolumn{2}{|c|}{1967} & \multicolumn{2}{|c|}{1987} & \multicolumn{2}{|c|}{ Change } \\
\hline & $\begin{array}{c}\text { Square } \\
\text { miles }\end{array}$ & $\begin{array}{c}\text { Percentage } \\
\text { of drainage } \\
\text { area }\end{array}$ & $\begin{array}{c}\text { Square } \\
\text { miles }\end{array}$ & $\begin{array}{c}\text { Percentage } \\
\text { of drainage } \\
\text { area }\end{array}$ & $\begin{array}{l}\text { Square } \\
\text { miles }\end{array}$ & $\begin{array}{c}\text { Percentage } \\
\text { of drainage } \\
\text { area }\end{array}$ \\
\hline \multicolumn{7}{|c|}{ Site 4} \\
\hline Open space & 8.01 & 29.1 & 6.87 & 25.0 & -1.14 & -4.2 \\
\hline Agricultural & 12.29 & 44.7 & 6.66 & 24.2 & -5.63 & -20.5 \\
\hline Pasture & 6.09 & 22.1 & 5.38 & 19.6 & -.71 & -2.6 \\
\hline Specialized agriculture & .11 & .4 & .06 & .2 & -.05 & -.2 \\
\hline Residential & .86 & 3.1 & 7.47 & 27.2 & 6.61 & 24.0 \\
\hline Commercial & .00 & .0 & .23 & .8 & .23 & .8 \\
\hline Industrial & .14 & .5 & .83 & 3.0 & .69 & 2.5 \\
\hline \multicolumn{7}{|c|}{ Site 5} \\
\hline Open space & 9.62 & 30.6 & 8.03 & 25.6 & -1.59 & -5.1 \\
\hline Agricultural & 13.60 & 43.3 & 6.97 & 22.2 & -6.63 & -21.1 \\
\hline Pasture & 6.76 & 21.5 & 6.22 & 19.8 & -.54 & -1.7 \\
\hline Specialized agriculture & .11 & .3 & .06 & .2 & -.05 & -.2 \\
\hline Residential & 1.10 & 3.5 & 8.92 & 28.4 & 7.82 & 24.9 \\
\hline Commercial & .00 & .0 & .23 & .7 & .23 & .7 \\
\hline Industrial & .21 & .7 & .97 & 3.1 & .76 & 2.4 \\
\hline \multicolumn{7}{|c|}{ Site 6} \\
\hline Open space & .23 & 11.6 & .23 & 11.5 & .00 & .0 \\
\hline Agricultural & 1.34 & 67.2 & .87 & 43.5 & -1.05 & -52.6 \\
\hline Pasture & .40 & 19.8 & .32 & 16.0 & .08 & -4.0 \\
\hline Specialized agriculture & .03 & 1.4 & .02 & 1.0 & -.01 & -.5 \\
\hline Residential & .00 & .0 & .56 & 28.0 & .56 & 28.0 \\
\hline \multicolumn{7}{|c|}{ Site 10} \\
\hline Open space & 3.69 & 30.8 & 3.27 & 27.2 & -.42 & -3.5 \\
\hline Agricultural & 4.82 & 40.2 & 3.62 & 30.2 & -1.20 & -10.0 \\
\hline Pasture & 2.59 & 21.6 & .63 & 5.2 & -1.96 & -16.3 \\
\hline Specialized agriculture & .20 & 1.7 & .16 & 1.3 & -.04 & -.3 \\
\hline Residential & .64 & 5.3 & 4.16 & 34.7 & 3.52 & 29.3 \\
\hline Commercial & .06 & .5 & .16 & 1.3 & .10 & .8 \\
\hline \multicolumn{7}{|c|}{ Site 12} \\
\hline Open space & 4.54 & 36.6 & 4.58 & 36.9 & .04 & .3 \\
\hline Agricultural & 3.94 & 31.8 & 3.21 & 25.9 & -.73 & -5.9 \\
\hline Pasture & 3.63 & 29.3 & 2.90 & 23.4 & -.73 & -5.9 \\
\hline Specialized agriculture & .05 & .4 & .03 & .2 & -.02 & -.2 \\
\hline Residential & .24 & 1.9 & 1.56 & 12.6 & 1.32 & 10.6 \\
\hline Commercial & .00 & .0 & .00 & .0 & .00 & .0 \\
\hline Industrial & .00 & .0 & .12 & 1.0 & .12 & 1.0 \\
\hline \multicolumn{7}{|c|}{ Site 13} \\
\hline Open space & 15.54 & 66.9 & 15.03 & 64.7 & -.51 & -2.2 \\
\hline Agricultural & 4.22 & 18.2 & 3.07 & 13.2 & -1.15 & -5.0 \\
\hline Pasture & 3.19 & 13.7 & 2.33 & 10.0 & -.86 & -3.7 \\
\hline Residential & .29 & 1.2 & 2.69 & 11.6 & 2.40 & 10.3 \\
\hline Commercial & .00 & .0 & .12 & .5 & .12 & .5 \\
\hline \multicolumn{7}{|c|}{ Site 14} \\
\hline Open space & 24.99 & 53.5 & 24.14 & 52.4 & .85 & -1.8 \\
\hline Agricultural & 11.66 & 25.3 & 9.10 & 19.7 & -2.56 & -5.6 \\
\hline Pasture & 8.76 & 19.0 & 5.99 & 13.0 & -2.77 & -6.0 \\
\hline Specialized agriculture & .11 & .2 & .03 & .1 & -.08 & -.2 \\
\hline Residential & .87 & 1.9 & 6.34 & 13.8 & 5.47 & 11.9 \\
\hline Commercial & .03 & .1 & .38 & .8 & .35 & .8 \\
\hline Industrial & .00 & .0 & .12 & .3 & .12 & .3 \\
\hline
\end{tabular}


Table 2. Changes in land use within drainage areas of selected stream sites in Chester County, Pa., 1967-87-Continued

[Rounding may account for differences.]

\begin{tabular}{|c|c|c|c|c|c|c|}
\hline \multirow[b]{2}{*}{$\begin{array}{l}\text { Land-use } \\
\text { category }\end{array}$} & \multicolumn{2}{|c|}{1967} & \multicolumn{2}{|c|}{1987} & \multicolumn{2}{|c|}{ Change } \\
\hline & $\begin{array}{l}\text { Square } \\
\text { miles }\end{array}$ & $\begin{array}{c}\text { Percentage } \\
\text { of drainage } \\
\text { area }\end{array}$ & $\begin{array}{c}\text { Square } \\
\text { miles }\end{array}$ & $\begin{array}{c}\text { Percentage } \\
\text { of drainage } \\
\text { area }\end{array}$ & $\begin{array}{l}\text { Square } \\
\text { miles }\end{array}$ & $\begin{array}{c}\text { Percentage } \\
\text { of drainage } \\
\text { area }\end{array}$ \\
\hline \multicolumn{7}{|c|}{ Site 15} \\
\hline Open space & 27.36 & 49.2 & 27.61 & 48.3 & 0.24 & -0.9 \\
\hline Agricultural & 15.20 & 27.3 & 12.29 & 21.5 & -2.92 & -5.8 \\
\hline Pasture & 11.80 & 21.2 & 7.38 & 12.9 & -4.41 & -8.3 \\
\hline Specialized agriculture & .13 & .2 & .03 & .0 & -.10 & -.2 \\
\hline Residential & 1.14 & 2.0 & 9.32 & 16.3 & 8.18 & 14.3 \\
\hline Commercial & .03 & .1 & .40 & .7 & .38 & .7 \\
\hline Industrial & .00 & .0 & .12 & .2 & .12 & .2 \\
\hline \multicolumn{7}{|c|}{ Site 17} \\
\hline Open space & .97 & 18.8 & .70 & 13.6 & -.27 & -5.2 \\
\hline Agricultural & .31 & 6.0 & .01 & .2 & -.30 & -5.8 \\
\hline Pasture & .78 & 15.2 & .15 & 2.9 & -.63 & -12.2 \\
\hline Residential & 2.85 & 55.3 & 3.89 & 75.5 & 1.04 & 20.2 \\
\hline Industrial & .00 & .0 & .02 & .4 & -.02 & .4 \\
\hline Commercial & .24 & 4.7 & .38 & 7.34 & .14 & 2.7 \\
\hline \multicolumn{7}{|c|}{ Site 19} \\
\hline Open space & 2.63 & 26.1 & 1.97 & 19.5 & -.66 & -6.5 \\
\hline Agricultural & 1.24 & 12.2 & .65 & 6.4 & -.59 & -5.8 \\
\hline Pasture & 1.97 & 19.5 & .32 & 3.2 & -1.65 & -16.3 \\
\hline Specialized agriculture & .51 & 5.3 & .54 & 5.4 & .03 & .3 \\
\hline Residential & 3.21 & 31.8 & 6.01 & 59.5 & 2.80 & 27.7 \\
\hline Commercial & .54 & 5.1 & .61 & 6.0 & .07 & .7 \\
\hline \multicolumn{7}{|c|}{ Site 20 } \\
\hline Open space & 1.10 & 26.0 & .94 & 22.3 & -.16 & -3.8 \\
\hline Agricultural & 1.58 & 37.4 & .11 & 2.6 & -1.47 & -34.8 \\
\hline Pasture & .63 & 15.1 & .33 & 7.8 & -.30 & -7.1 \\
\hline Specialized agriculture & .18 & 4.2 & .17 & 4.0 & -.01 & -.2 \\
\hline Residential & .61 & 14.4 & 2.42 & 57.4 & 1.81 & 42.9 \\
\hline Commercial & .12 & 2.9 & .16 & 3.8 & .04 & 1.0 \\
\hline Industrial & .00 & .0 & .09 & 2.0 & .09 & 2.1 \\
\hline \multicolumn{7}{|c|}{ Site 21} \\
\hline Open space & 2.17 & 22.4 & 1.63 & 16.8 & -.54 & -5.6 \\
\hline Agricultural & 4.09 & 42.1 & .92 & 9.4 & -3.17 & -32.6 \\
\hline Pasture & 1.60 & 16.5 & 1.23 & 12.6 & -.37 & -3.8 \\
\hline Specialized agriculture & .21 & 2.1 & .18 & 1.8 & -.03 & -.3 \\
\hline Residential & 1.46 & 15.1 & 5.29 & 54.5 & 3.83 & 39.4 \\
\hline Commercial & .18 & 1.8 & .27 & 2.8 & .09 & .9 \\
\hline Industrial & .00 & .0 & .19 & 2.0 & .19 & 2.0 \\
\hline \multicolumn{7}{|c|}{ Site 22 } \\
\hline Open space & .02 & 1.9 & .20 & 18.9 & .18 & 17.0 \\
\hline Agricultural & .12 & 11.3 & .00 & .0 & -.12 & -11.3 \\
\hline Pasture & .36 & 34.0 & .05 & 4.7 & -.31 & -29.2 \\
\hline Residential & .56 & 52.8 & .78 & 73.6 & .22 & 20.8 \\
\hline Commercial & .00 & .0 & .03 & 2.8 & .03 & 2.8 \\
\hline \multicolumn{7}{|c|}{ Site 23 } \\
\hline Open space & 1.14 & 19.8 & .76 & 13.2 & -.38 & -6.6 \\
\hline Agricultural & 1.56 & 27.0 & .24 & 4.2 & -1.32 & -22.9 \\
\hline Pasture & 1.21 & 21.0 & .66 & 11.4 & -.55 & -9.5 \\
\hline Residential & 1.86 & 32.2 & 3.06 & 53.0 & 1.20 & 20.8 \\
\hline Commercial & .00 & .0 & .16 & 2.8 & .16 & 2.8 \\
\hline Industrial & .00 & .0 & .89 & 15.4 & .89 & 15.4 \\
\hline
\end{tabular}


Table 2. Changes in land use within drainage areas of selected stream sites in Chester County, Pa., 1967-87-Continued

[Rounding may account for differences.]

\begin{tabular}{|c|c|c|c|c|c|c|}
\hline \multirow[b]{2}{*}{$\begin{array}{l}\text { Land-use } \\
\text { category }\end{array}$} & \multicolumn{2}{|c|}{1967} & \multicolumn{2}{|c|}{1987} & \multicolumn{2}{|c|}{ Change } \\
\hline & $\begin{array}{l}\text { Square } \\
\text { miles }\end{array}$ & $\begin{array}{c}\text { Percentage } \\
\text { of drainage } \\
\text { area }\end{array}$ & $\begin{array}{l}\text { Square } \\
\text { miles }\end{array}$ & $\begin{array}{l}\text { Percentage } \\
\text { of drainage } \\
\text { area }\end{array}$ & $\begin{array}{l}\text { Square } \\
\text { miles }\end{array}$ & $\begin{array}{c}\text { Percentage } \\
\text { of drainage } \\
\text { area }\end{array}$ \\
\hline \multicolumn{7}{|c|}{ Site 24} \\
\hline Open space & 2.01 & 19.3 & 1.14 & 11.0 & -0.87 & -8.4 \\
\hline Agricultural & 2.53 & 24.3 & .28 & 2.7 & -2.25 & -21.6 \\
\hline Pasture & 2.58 & 24.8 & .92 & 8.8 & -1.66 & -16.0 \\
\hline Specialized agriculture & .24 & 2.3 & .12 & 1.2 & -.12 & -1.2 \\
\hline Residential & 2.96 & 28.5 & 6.52 & 62.7 & 3.56 & 34.2 \\
\hline Commercial & .08 & .8 & .51 & 4.9 & .43 & 4.1 \\
\hline Industrial & .00 & .0 & .91 & 8.8 & .91 & 8.8 \\
\hline \multicolumn{7}{|c|}{ Site 27} \\
\hline Open space & 1.69 & 17.3 & 1.70 & 17.4 & .01 & .1 \\
\hline Agricultural & 2.61 & 26.7 & 2.20 & 22.5 & -.41 & -4.2 \\
\hline Pasture & 3.81 & 38.9 & 2.83 & 28.9 & -.98 & -10.0 \\
\hline Specialized agriculture & .31 & 3.2 & .34 & 3.5 & .03 & .3 \\
\hline Residential & 1.24 & 12.7 & 2.34 & 23.9 & 1.10 & 11.2 \\
\hline Commercial & .09 & .9 & .19 & 1.9 & .10 & 1.0 \\
\hline Industrial & .04 & .4 & .19 & 1.9 & .15 & 1.5 \\
\hline \multicolumn{7}{|c|}{ Site 28 } \\
\hline Open space & 2.32 & 20.5 & 2.64 & 23.4 & .32 & 2.8 \\
\hline Agricultural & 4.47 & 39.5 & 4.19 & 37.1 & -.28 & -2.5 \\
\hline Pasture & 3.91 & 34.6 & 2.96 & 26.2 & -.95 & -8.4 \\
\hline Specialized agriculture & .33 & 2.9 & .32 & 2.8 & -.01 & -.1 \\
\hline Residential & .24 & 2.1 & .85 & 7.5 & .61 & 5.4 \\
\hline Commercial & .00 & .0 & .24 & 2.1 & .24 & 2.1 \\
\hline Industrial & .04 & .4 & .10 & .9 & .06 & .5 \\
\hline \multicolumn{7}{|c|}{ Site 34} \\
\hline Open space & 2.22 & 21.1 & 2.09 & 19.9 & -.13 & -1.2 \\
\hline Agricultural & 5.86 & 55.8 & 4.84 & 46.1 & -1.02 & -9.7 \\
\hline Pasture & 1.84 & 17.5 & 1.02 & 9.7 & -.82 & -7.8 \\
\hline Specialized agriculture & .12 & 1.1 & .09 & .9 & -.03 & -.3 \\
\hline Residential & .37 & 3.5 & 1.97 & 18.8 & 1.60 & 15.2 \\
\hline Commercial & .06 & .6 & .42 & 4.0 & .36 & 3.4 \\
\hline Industrial & .03 & .3 & .07 & .7 & .04 & .4 \\
\hline \multicolumn{7}{|c|}{ Site 44} \\
\hline Open space & 6.47 & 31.9 & 4.76 & 23.4 & -1.71 & -10.6 \\
\hline Agricultural & 6.09 & 30.0 & 1.88 & 9.3 & -4.21 & -26.2 \\
\hline Pasture & 3.73 & 18.4 & 2.29 & 11.3 & -1.44 & -8.9 \\
\hline Specialized agriculture & .36 & 1.8 & .26 & 1.3 & -.10 & -.6 \\
\hline Residential & 2.65 & 13.1 & 8.19 & 40.3 & 5.54 & 34.4 \\
\hline Commercial & .62 & 3.1 & 1.56 & 7.7 & .94 & 5.8 \\
\hline Industrial & .38 & 1.9 & 1.36 & 6.6 & .98 & 6.1 \\
\hline \multicolumn{7}{|c|}{ Site 45} \\
\hline Open space & 2.38 & 20.2 & 2.30 & 19.5 & -.08 & -.7 \\
\hline Agricultural & 5.59 & 47.4 & 5.09 & 43.1 & -.50 & -4.2 \\
\hline Pasture & 3.57 & 30.2 & 3.28 & 27.8 & -.29 & -2.5 \\
\hline Specialized agriculture & .08 & .7 & .00 & .0 & -.08 & -.7 \\
\hline Residential & .18 & 1.5 & 1.13 & 9.6 & .95 & 8.0 \\
\hline \multicolumn{7}{|c|}{ Site 47} \\
\hline Open space & 2.06 & 48.4 & 1.60 & 37.6 & -.46 & -10.8 \\
\hline Agricultural & 1.71 & 40.1 & .22 & 5.2 & -1.49 & -35.0 \\
\hline Pasture & .39 & 9.2 & 1.33 & 31.2 & .94 & 22.1 \\
\hline Residential & .05 & 1.2 & 1.08 & 25.4 & 1.03 & 24.1 \\
\hline Industrial & .05 & 1.2 & .03 & .7 & -.02 & -.5 \\
\hline
\end{tabular}


Table 2. Changes in land use within drainage areas of selected stream sites in Chester County, Pa., 1967-87-Continued

[Rounding may account for differences.]

\begin{tabular}{|c|c|c|c|c|c|c|}
\hline \multirow[b]{2}{*}{$\begin{array}{l}\text { Land-use } \\
\text { category }\end{array}$} & \multicolumn{2}{|c|}{1967} & \multicolumn{2}{|c|}{1987} & \multicolumn{2}{|c|}{ Change } \\
\hline & $\begin{array}{c}\text { Square } \\
\text { miles }\end{array}$ & $\begin{array}{l}\text { Percentage } \\
\text { of drainage } \\
\text { area }\end{array}$ & $\begin{array}{c}\text { Square } \\
\text { miles }\end{array}$ & $\begin{array}{c}\text { Percentage } \\
\text { of drainage } \\
\text { area }\end{array}$ & $\begin{array}{c}\text { Square } \\
\text { miles }\end{array}$ & $\begin{array}{c}\text { Percentage } \\
\text { of drainage } \\
\text { area }\end{array}$ \\
\hline \multicolumn{7}{|c|}{ Site 49} \\
\hline Open space & 1.35 & $20 . \overline{9}$ & 1.37 & 21.2 & 0.02 & 0.3 \\
\hline Agricultural & .98 & 15.2 & .19 & 3.0 & -.79 & -12.2 \\
\hline Pasture & 1.04 & 16.1 & .62 & 9.6 & -.42 & -6.5 \\
\hline Residential & 2.36 & 36.6 & 2.62 & 40.6 & .26 & 4.0 \\
\hline Commercial & .18 & 2.8 & .40 & 6.2 & .22 & 3.4 \\
\hline Industrial & .54 & 8.4 & 1.25 & 19.4 & .71 & 11.0 \\
\hline \multicolumn{7}{|c|}{ Site 50} \\
\hline Open space & 3.07 & 24.1 & 3.33 & 26.2 & .26 & 2.0 \\
\hline Agricultural & 4.01 & 31.5 & .35 & 2.8 & -3.66 & -28.8 \\
\hline Pasture & 1.73 & 13.6 & .60 & 4.7 & -1.13 & -8.9 \\
\hline Specialized agriculture & .44 & 3.5 & .52 & 4.1 & .08 & .6 \\
\hline Residential & 2.74 & 21.5 & 4.62 & 36.4 & 1.88 & 14.8 \\
\hline Commercial & .26 & 2.0 & .62 & 4.9 & .36 & 2.8 \\
\hline Industrial & .47 & 3.7 & 2.66 & 21.0 & 2.19 & 17.2 \\
\hline
\end{tabular}




\section{ORGANOCHLORINE COMPOUNDS}

\section{Icedale Lake Sediment Cores}

Accumulated sediments at the site of Icedale Lake, a drained reservoir on West Branch Brandywine Creek (fig. 1), provided an opportunity to examine relative influx of organochlorine compounds to the stream over time. The lake was a small reservoir built in 1913 to allow wintertime ice production. In 1984, a breach in the dam drained the reservoir, leaving a large amount of accumulated sediment. Like most basins in the study area, the Icedale Lake Basin has experienced increased residential development and subsequent decreases in agricultural land use, pasture, and open space (table 3).

Three cores of accumulated sediments were collected by driving 6-in. diameter PVC pipe into the old lake bed. Resistance to driving by rock or gravel was considered to be the bottom of the accumulated sediment. The cores were extruded from the pipes in 2-cm segments. The outermost part of each extruded core segment was removed to minimize smearing problems, and the central part was analyzed for lead-210 and cesium-137 activities, silt and clay content, and concentrations of selected organochlorine compounds and organic carbon. The radioactive elements were analyzed at a contract laboratory according to the methods of the National Council on Radiation Protection and Measurements (1985) and the American Society for Testing and Materials (1987). The silt and clay contents were determined at the USGS Pennsylvania District Sediment Laboratory by sieving technique. Analyses of organic carbon and organochlorine compounds were performed by the USGS National WaterQuality Laboratory according to the methods of Wershaw and others (1987, p. 17-22 and 3135). Compaction errors for the three cores were small and ranged from 0 to 4 percent of the core depths. Therefore, data from same depth segments in each core were considered comparable.

Table 3. Change in land use for Icedale Lake Basin, Chester County, Pa., 1967-87

\begin{tabular}{|c|c|c|c|c|c|c|}
\hline \multirow[b]{2}{*}{$\begin{array}{l}\text { Land-use } \\
\text { category }\end{array}$} & \multicolumn{2}{|c|}{1967} & \multicolumn{2}{|c|}{1987} & \multicolumn{2}{|c|}{ Change } \\
\hline & $\begin{array}{c}\text { Square } \\
\text { miles }\end{array}$ & $\begin{array}{c}\text { Percentage } \\
\text { of drainage } \\
\text { area }\end{array}$ & $\begin{array}{c}\text { Square } \\
\text { miles }\end{array}$ & $\begin{array}{c}\text { Percentage } \\
\text { of drainage } \\
\text { area }\end{array}$ & $\begin{array}{c}\text { Square } \\
\text { miles }\end{array}$ & $\begin{array}{c}\text { Percentage } \\
\text { of drainage } \\
\text { area }\end{array}$ \\
\hline Open space & 6.38 & 32.4 & 5.46 & 27.6 & -0.92 & -4.8 \\
\hline Cropland & 9.98 & 50.7 & 8.89 & 44.9 & -1.09 & -5.8 \\
\hline Pasture & 2.45 & 12.5 & 1.99 & 10.1 & -.46 & -2.4 \\
\hline Residential & .80 & 4.1 & 3.14 & 15.8 & 2.34 & 11.8 \\
\hline Commercial & .00 & .0 & .07 & .3 & .07 & .3 \\
\hline Industrial & .08 & .4 & .26 & .3 & .18 & .9 \\
\hline
\end{tabular}




\section{Core Dating}

Estimates of the times of deposition for core segments were made by estimating the amount of annual sediment loads for the Brandywine Creek at Chadds Ford. Because the accuracy of these estimates could be affected by unknown changes in sediment transport caused by land-use changes (table 3 ), the estimates were compared to cesium-137 activities in the core segments. Although lead-210 data also were collected for dating purposes, activities were less than $1.25 \mathrm{pCi} / \mathrm{g}$ in all core segments and were considered too small and variable for dating purposes.

The USGS streamflow-gaging station at Chadds Ford (fig. 1) has streamflow data from 1912 to 1955 and continuously since 1963. Suspended-sediment data were collected from 1964 to 1978. Assuming that peak-flow events transported most sediment to the lake, annual sediment loads for the period of record $(1964-78)$ were correlated $(r=0.76, p=<0.05)$ with the annual peak discharges exceeding $6,000 \mathrm{ft}^{3} / \mathrm{s}$ (fig. 2). By use of this relation, annual sediment loads were calculated for all years that the lake existed except for 1956-63, when discharge data were not collected. About 10 percent of the sediment discharged to the lake during the period of missing record. The amount of sediment discharged for individual years was divided by the total sediment discharged from 1913 to 1984 and multiplied by the core depth to assign approximate deposition years to the core. The depth of the shallowest core $(32 \mathrm{~cm})$ was used as total depth because the deeper cores $(40$ and $50 \mathrm{~cm})$ are thought to represent lowelevation areas of the lakebed that might have accumulated disproportionately large amounts of sediment in the early period of the reservoir's existence.

Cesium-137 fallout is a product of atmospheric nuclear detonations. Activities in the core segments (table 4) were used to determine the reasonability of the calculated deposition years. Because metals like cesium (which has a high affinity for sediment attachment) have disproportionately higher concentrations on fine particles compared to coarse particles, the core-segment activities were normalized for silt and clay content according to methods used by Horowitz (1991, p. 84) and compared to the calculated deposition periods in figure 3 . The largest cesium-137 peak on figure $3($ at $9-13 \mathrm{~cm}$ ) is considered representative of cesium-137 deposition to the basin during the highest fallout period from 1959 to 1966 (Ritchie and others, 1973). This suggests a lag time of about 2 or 3 years for transport to the reservoir and is considered reasonable for this analysis. The sharp decrease (at $7 \mathrm{~cm}$ ) and secondary peak (at $5 \mathrm{~cm}$ ) also correlate on a 2- to 3-year lag time with the low fallout rate in 1967 and subsequent increase reported by Ritchie and others (1973). 


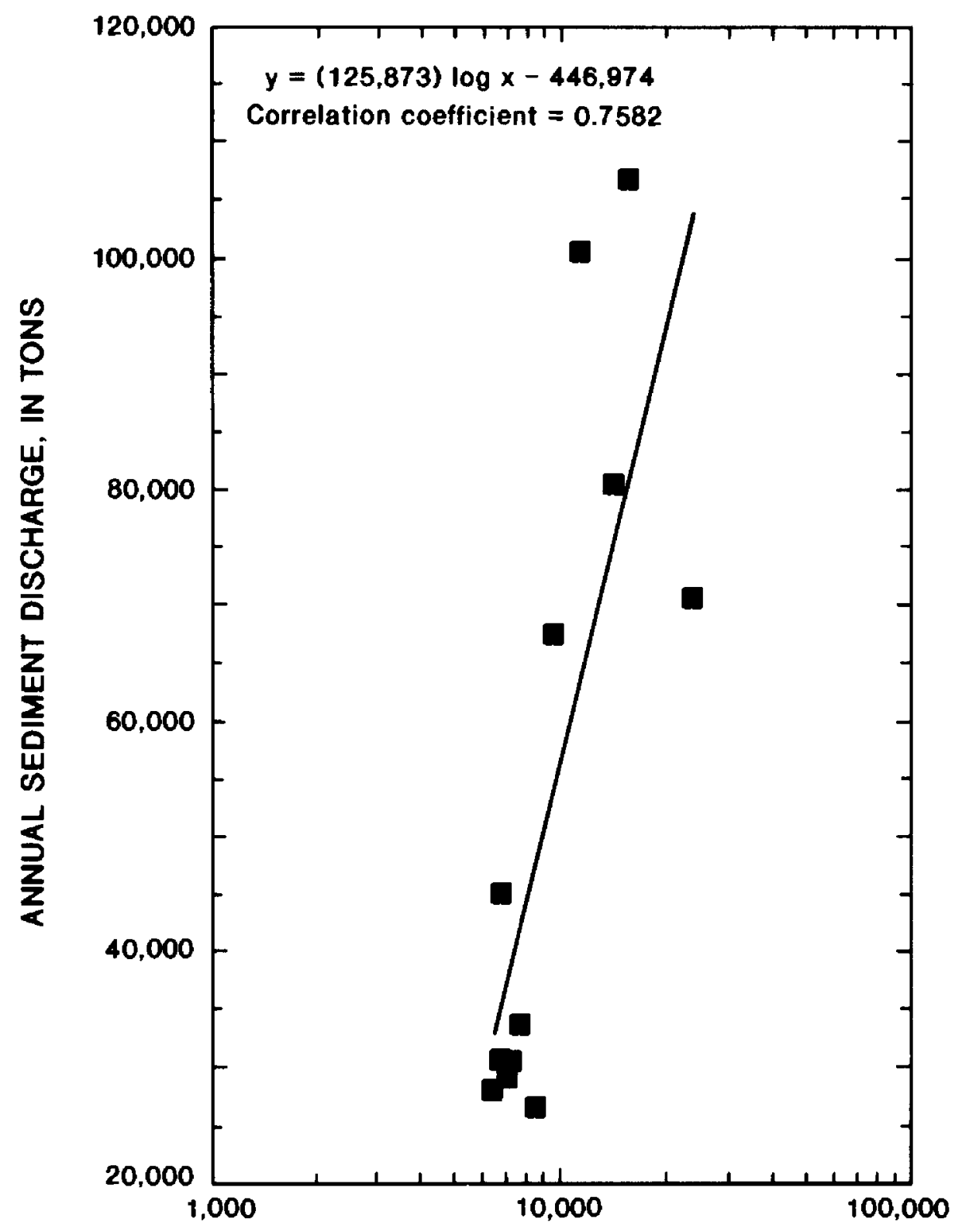

Figure 2. Relation between annual peak flows and annual sediment discharge at Brandywine Creek at Chadds Ford, 1964-78

ANNUAL PEAK DISCHARGE, IN CUBIC FEET PER SECOND

Figure 3. Depth profile of ratio of cesium-137 and silt-clay fraction in bottom materials of Icedale Lake, Chester County, Pa.

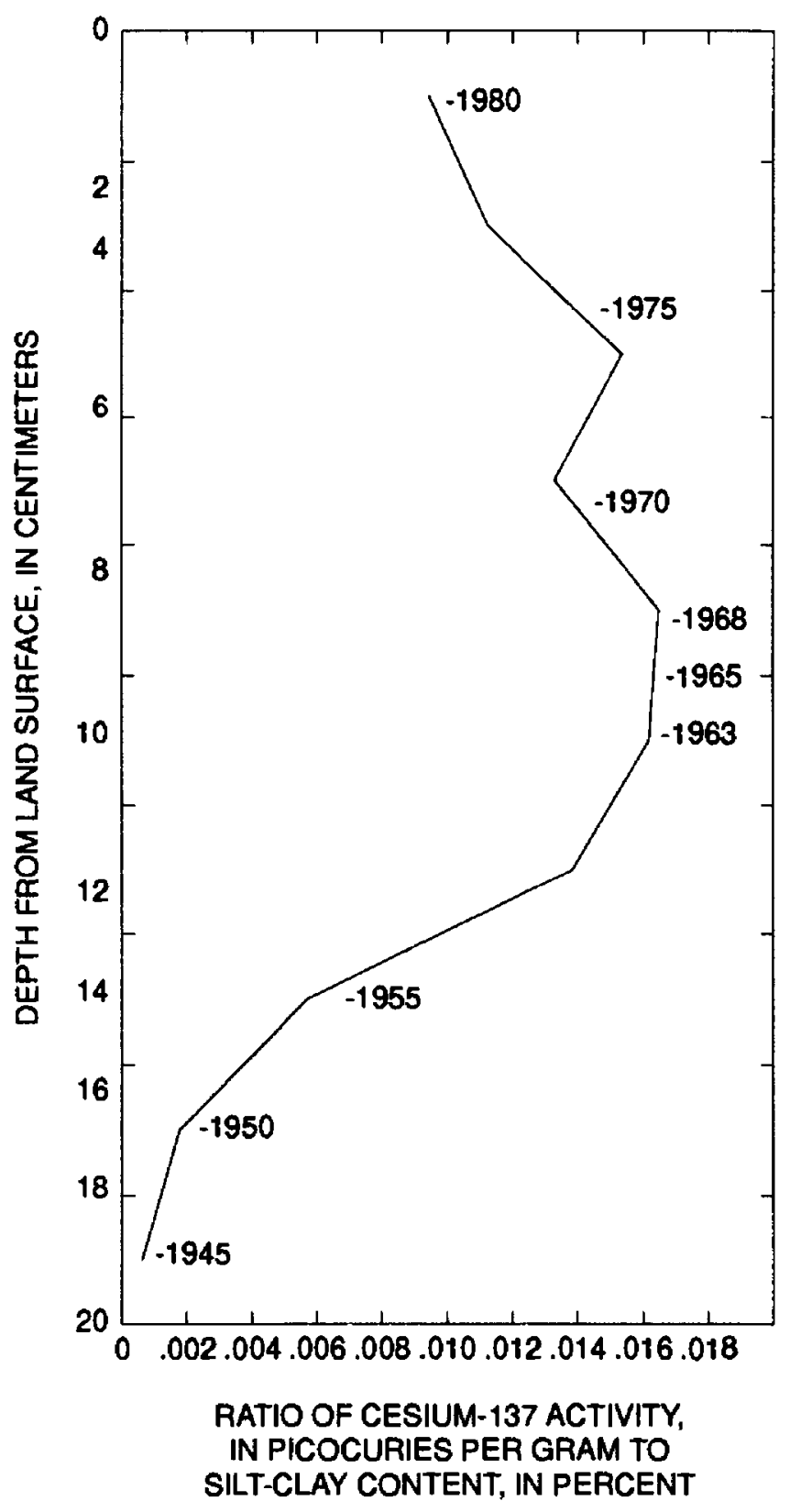


Table 4. Concentrations of carbon and organochlorine compounds, Cesium-137 activities, and silt and clay sized particles in bottom materials at selected depths from Icedale Lake, Chester County, Pa., September 1988

[cm, centimeter; $\mu \mathrm{g} / \mathrm{kg}$, microgram per kilogram; $\mathrm{g} / \mathrm{kg}$, gram per kilogram; <, less than; $\mathrm{pCi} / \mathrm{g}$, picoCurie per gram; $\mu \mathrm{m}$, micrometer]

\begin{tabular}{cccccccccccc}
\hline $\begin{array}{c}\text { Depth } \\
(\mathrm{cm})\end{array}$ & $\begin{array}{c}\text { Aldrin, } \\
\text { total } \\
(\mu \mathrm{g} / \mathrm{kg})\end{array}$ & $\begin{array}{c}\text { Chlordane, } \\
\text { total } \\
(\mu \mathrm{g} / \mathrm{kg})\end{array}$ & $\begin{array}{c}\text { DDD, } \\
\text { total } \\
(\mu \mathrm{g} / \mathrm{kg})\end{array}$ & $\begin{array}{c}\text { DDE, } \\
\text { total } \\
(\mu \mathrm{g} / \mathrm{kg})\end{array}$ & $\begin{array}{c}\text { DDT, } \\
\text { total } \\
(\mu \mathrm{g} / \mathrm{kg})\end{array}$ & $\begin{array}{c}\text { Dieldrin, } \\
\text { total } \\
(\mu \mathrm{g} / \mathrm{kg})\end{array}$ & $\begin{array}{c}\text { Endosulfan, } \\
\text { total } \\
(\mu \mathrm{g} / \mathrm{kg})\end{array}$ & $\begin{array}{c}\text { Endrin, } \\
\text { total } \\
(\mu \mathrm{g} / \mathrm{kg})\end{array}$ & $\begin{array}{c}\text { PCB, } \\
\text { total } \\
(\mu \mathrm{g} / \mathrm{kg})\end{array}$ & $\begin{array}{c}\text { PCN, } \\
\text { total } \\
(\mu \mathrm{g} / \mathrm{kg})\end{array}$ & $\begin{array}{c}\text { Heptachlor, } \\
\text { total } \\
(\mu \mathrm{g} / \mathrm{kg})\end{array}$ \\
\hline $0-2$ & $<0.1$ & 4.0 & 0.8 & 1.9 & $<10$ & 0.4 & $<0.1$ & $<0.1$ & 5 & $<1.0$ & $<0.1$ \\
$2-4$ & $<.1$ & 3.0 & .6 & 2.1 & $<10$ & .4 & $<.1$ & $<.1$ & 6 & $<1.0$ & $<.1$ \\
$4-6$ & $<.1$ & 3.0 & .6 & 2.1 & $<10$ & .3 & $<.1$ & $<.1$ & 5 & $<1.0$ & $<.1$ \\
$6-8$ & $<.1$ & 3.0 & .6 & 2.1 & $<10$ & .3 & $<.1$ & $<.1$ & 5 & $<1.0$ & $<.1$ \\
$8-10$ & $<.1$ & 4.0 & .8 & 2.5 & $<10$ & .4 & $<.1$ & $<.1$ & 7 & $<1.0$ & $<.1$ \\
$10-12$ & $<.1$ & 4.0 & 1.2 & 2.9 & $<10$ & .4 & $<.1$ & $<.1$ & 3 & $<1.0$ & $<.1$ \\
$12-14$ & $<.1$ & 3.0 & 1.8 & 3.4 & $<10$ & .3 & $<.1$ & $<.1$ & 7 & $<1.0$ & $<.1$ \\
$14-16$ & $<.1$ & 2.0 & 2.9 & 3.6 & $<10$ & .2 & $<.1$ & $<.1$ & 6 & $<1.0$ & $<.1$ \\
$16-18$ & $<.1$ & 2.0 & 3.4 & 4.1 & $<10$ & .1 & $<.1$ & $<.1$ & 7 & $<1.0$ & $<.1$ \\
$18-20$ & $<.1$ & 2.0 & 2.5 & 2.9 & $<10$ & $<.1$ & $<.1$ & $<.1$ & 4 & $<1.0$ & $<.1$ \\
$20-22$ & $<.1$ & 1.0 & 1.0 & 1.4 & $<10$ & $<.1$ & $<.1$ & $<.1$ & 3 & $<1.0$ & $<.1$ \\
$22-24$ & $<.1$ & $<1.0$ & .3 & .5 & $<10$ & $<.1$ & $<.1$ & $<.1$ & 3 & $<1.0$ & $<.1$ \\
$24-26$ & $<.1$ & $<1.0$ & $<.1$ & .1 & $<.1$ & $<.1$ & $<.1$ & $<.1$ & $<1$ & $<1.0$ & $<.1$ \\
$26-28$ & $<.1$ & $<1.0$ & $<.1$ & .1 & $<.1$ & $<.1$ & $<.1$ & $<.1$ & $<1$ & $<1.0$ & $<.1$ \\
$28-30$ & $<.1$ & $<1.0$ & $<.1$ & .1 & $<.1$ & $<.1$ & $<.1$ & $<.1$ & $<1$ & $<1.0$ & $<.1$ \\
\hline
\end{tabular}

\begin{tabular}{|c|c|c|c|c|c|c|c|c|c|c|}
\hline $\begin{array}{c}\text { Depth } \\
\text { (cm) }\end{array}$ & $\begin{array}{l}\text { Heptachlor } \\
\text { epoxide, } \\
\text { total } \\
(\mu \mathrm{g} / \mathrm{kg})\end{array}$ & $\begin{array}{l}\text { Lindane, } \\
\text { tołal } \\
(\mu \mathrm{g} / \mathrm{kg})\end{array}$ & $\begin{array}{l}\text { Meth- } \\
\text { oxychlor, } \\
\text { total } \\
(\mu \mathrm{g} / \mathrm{kg})\end{array}$ & $\begin{array}{l}\text { Mirex, } \\
\text { total } \\
(\mu \mathrm{g} / \mathrm{kg})\end{array}$ & $\begin{array}{c}\text { Perthane, } \\
\text { total } \\
(\mu \mathrm{g} / \mathrm{kg})\end{array}$ & $\begin{array}{c}\text { Toxaphene, } \\
\text { total } \\
(\mu \mathrm{g} / \mathrm{kg})\end{array}$ & $\begin{array}{c}\text { Carbon, } \\
\text { inorganic } \\
\text { total } \\
(\mathrm{g} / \mathrm{kg} \\
\text { as C) }\end{array}$ & $\begin{array}{c}\text { Carbon, } \\
\text { inorg. + } \\
\text { organic, } \\
\text { total } \\
(\mathrm{g} / \mathrm{kg} \\
\text { as C) }\end{array}$ & $\begin{array}{c}\text { Cesium } \\
137 \\
\text { total } \\
(\mathrm{pCi} / \mathrm{g})\end{array}$ & $\begin{array}{c}\text { Grain size } \\
<63 \mu \mathrm{m} \\
\text { percent } \\
\text { of total }\end{array}$ \\
\hline$\overline{0-2}$ & $<0.1$ & $<0.1$ & $<0.1$ & $<0 . \overline{1}$ & $<1.00$ & $<10$ & $<0.1$ & 31 & 0.236 & 25 \\
\hline $2-4$ & $<.1$ & $<.1$ & $<.1$ & $<.1$ & 1.00 & $<10$ & $<.1$ & 27 & .315 & 28 \\
\hline $4-6$ & $<.1$ & $<.1$ & $<.1$ & $<.1$ & $<1.00$ & $<10$ & $<.1$ & 24 & .415 & 27 \\
\hline $6-8$ & $<.1$ & $<.1$ & $<.1$ & $<.1$ & $<1.00$ & $<10$ & $<.1$ & 23 & .386 & 29 \\
\hline $8-10$ & $<.1$ & $<.1$ & $<.1$ & $<.1$ & $<1.00$ & $<10$ & $<.1$ & 21 & .528 & 32 \\
\hline $10-12$ & $<.1$ & $<.1$ & $<.1$ & $<.1$ & $<1.00$ & $<10$ & $<.1$ & 23 & .550 & 34 \\
\hline $12-14$ & $<.1$ & $<.1$ & $<.1$ & $<.1$ & $<1.00$ & $<10$ & $<.1$ & 25 & .526 & 38 \\
\hline $14-16$ & $<.1$ & $<.1$ & $<.1$ & $<.1$ & $<1.00$ & $<10$ & $<.1$ & 25 & .194 & 34 \\
\hline $16-18$ & $<.1$ & $<.1$ & $<.1$ & $<.1$ & $<1.00$ & $<10$ & $<.1$ & 25 & .046 & 26 \\
\hline $18-20$ & $<.1$ & $<.1$ & $<.1$ & $<.1$ & $<1.00$ & $<10$ & $<.1$ & 24 & $<.020$ & 32 \\
\hline $20-22$ & $<.1$ & $<.1$ & $<.1$ & $<.1$ & $<1.00$ & $<10$ & $<.1$ & 22 & -- & 30 \\
\hline $22-24$ & $<.1$ & $<.1$ & $<.1$ & $<.1$ & $<1.00$ & $<10$ & $<1$ & 24 & -- & 27 \\
\hline $24-26$ & $<.1$ & $<.1$ & $<.1$ & $<.1$ & $<1.00$ & $<10$ & $<.1$ & 28 & -- & 30 \\
\hline $26-28$ & $<.1$ & $<.1$ & $<.1$ & $<.1$ & $<1.00$ & $<10$ & $<.1$ & 32 & -- & 31 \\
\hline $28-30$ & $<.1$ & $<.1$ & $<.1$ & $<.1$ & $<1.00$ & $<10$ & $<.1$ & 29 & - & 31 \\
\hline
\end{tabular}




\section{Compounds in Core Segments}

Five organochlorine compounds-chlordane, dieldrin (a commercial insecticide and biodegradation product of aldrin), PCB's, DDD, and DDE-were detected in the Icedale Lake core and represent primary-use compounds or degradation products that are resistant to further decomposition in the natural environment (Callahan and others, 1979). DDD and DDE typically reflect biodegradation of DDT (Johnsen, 1976). Because these nonionic organic compounds have a strong tendency to partition into organic material in the presence of water (Smith and others, 1988, p. 27-28), ratios of their concentrations and concentrations of organic carbon were used to normalize the data for more meaningful comparisons. The highest ratios suggest the periods of greatest influx of organochlorine compounds to the lake. Figure 3 compares these ratios for the detected compounds. Generally, data suggest the influx of the detected compounds was smaller in recent years than in the past, although only DDD, the compound most likely to be biodegraded (Johnsen, 1976), had recent ratios nearly as low as the oldest ones. Although DDT was not detected, the ratios of DDE and DDD suggest that the greatest effects of this pesticide were in the late 1940 's to early 1950 's, shortly after commercial production began in the United States. Influxes of chlordane and dieldrin seem to increase after 1950, while those of DDE and DDD decrease, suggesting that DDT use was gradually replaced by chlordane and dieldrin. The influx of chlordane and dieldrin appears to be greatest in the mid 1960's, corresponding closely with the peak farm use of aldrin and dieldrin (1966) and chlordane (1971) reported by Gilliom and others $(1985, \mathrm{p}$. 7). This usage peaked just before the biological monitoring program began in Chester County.

Two peaks are present for PCB's, one in the late 1950's and the other in the late 1960's. It is not known if this is related to use of PCB's as a pesticide extender (National Research Council, 1979, p. 3-4) or any of the many other wide-ranging historical uses for these compounds. Although greatest regional concentrations are commonly in industrial areas, atmospheric discharges (volatilization, incineration, etc.) contribute to their very widespread distribution (Smith and others, 1988, p. 30-32).

\section{Stream-Bottom Materials}

Bulk samples of stream-bottom materials were collected at 42 sites in the study area from October 1985 through November 1987 and analyzed for content of organochlorine pesticides and PCB's (table 5). The samples were collected from the top $2 \mathrm{~cm}$ of the stream bottom in depositional areas of the stream by use of stainless-steel scoops according to the methods of Wershaw and others (1987, p. 7-8). Analyses were performed by the USGS National Water-Quality Laboratory according to the methods of Wershaw and others (1987, p. 31-35).

The most frequently detected compounds were PCB's, chlordane, DDT, DDD, DDE, dieldrin, heptachlor epoxide, methoxychlor, and lindane (table 5). In a few instances, the minimum reporting levels ${ }^{1}$ exceeded those typically reported or no values are reported for some compounds. This is a result of interference caused by high concentrations of other target or nontarget compounds and the resulting subsample dilutions that sometimes must be made during analysis. Organochlorine compounds were detected at every site except one (site 46) located in the northwestern part of the study area. Methoxychlor was detected at only three sites (sites 1,39, and 49). Land-use analysis was done for the drainage areas of two of these three sites (sites 1 and 49). The data show that drainage areas for these sites were among the four areas having the greatest commercial land use in 1987 (greater than 6 percent). Methoxychlor is usually associated only with agricultural activities, has a short half-life compared to other organochlorine pesticides, and is rarely detected in the stream-bottom materials in stream basins where this pesticide is used (Gilliom and others, 1985, p. 9). Detection of methoxychlor at these sites might be a result of commercial construction activities on former agricultural lands.

${ }^{1}$ The smallest measured concentration of a constituent that may be reliably reported using a given analytical method. 

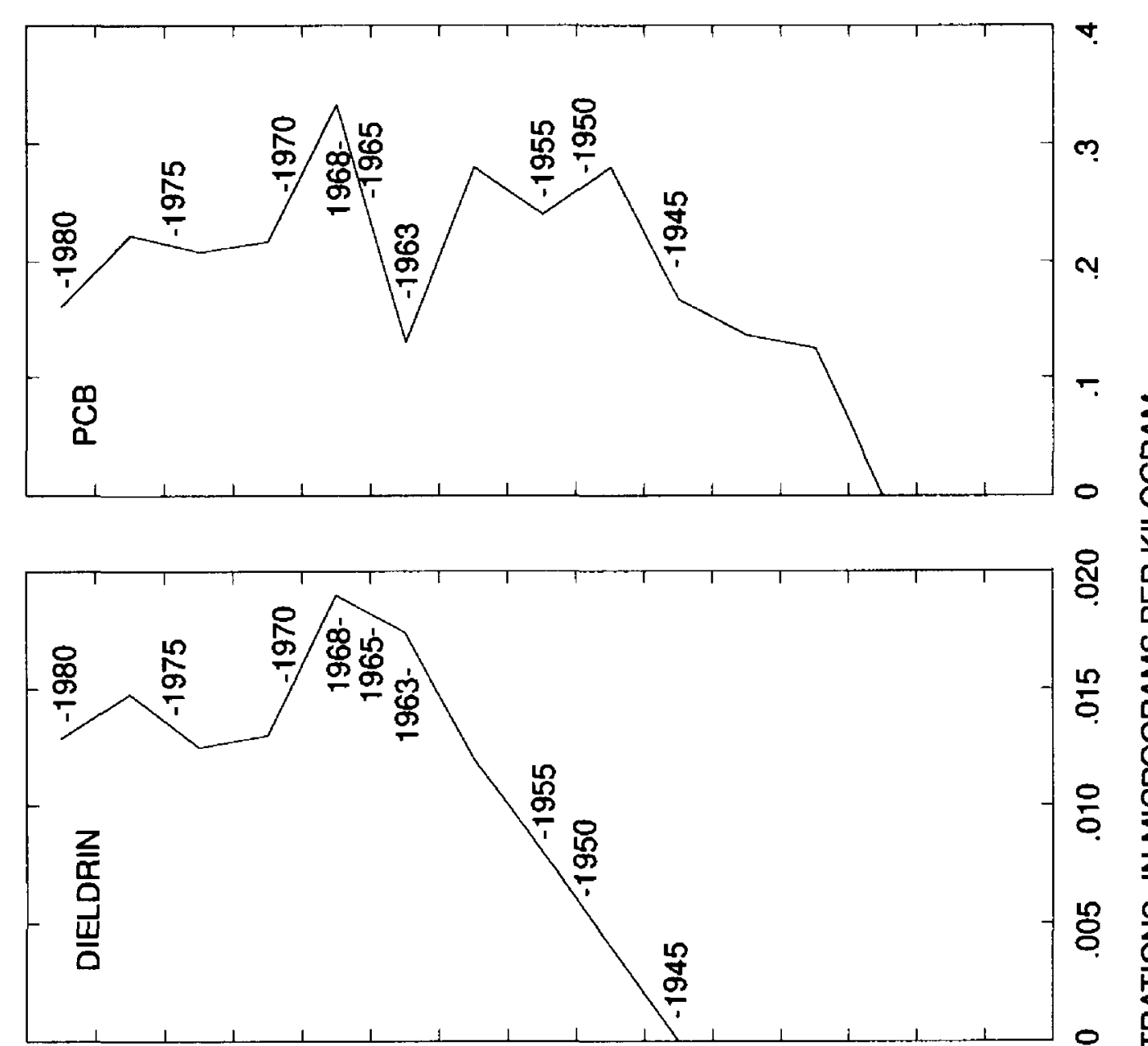

옹

ᄂ2)

.

웅

这

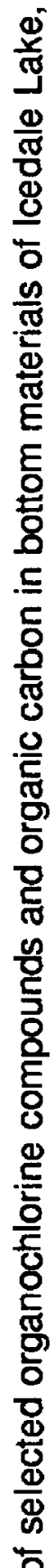

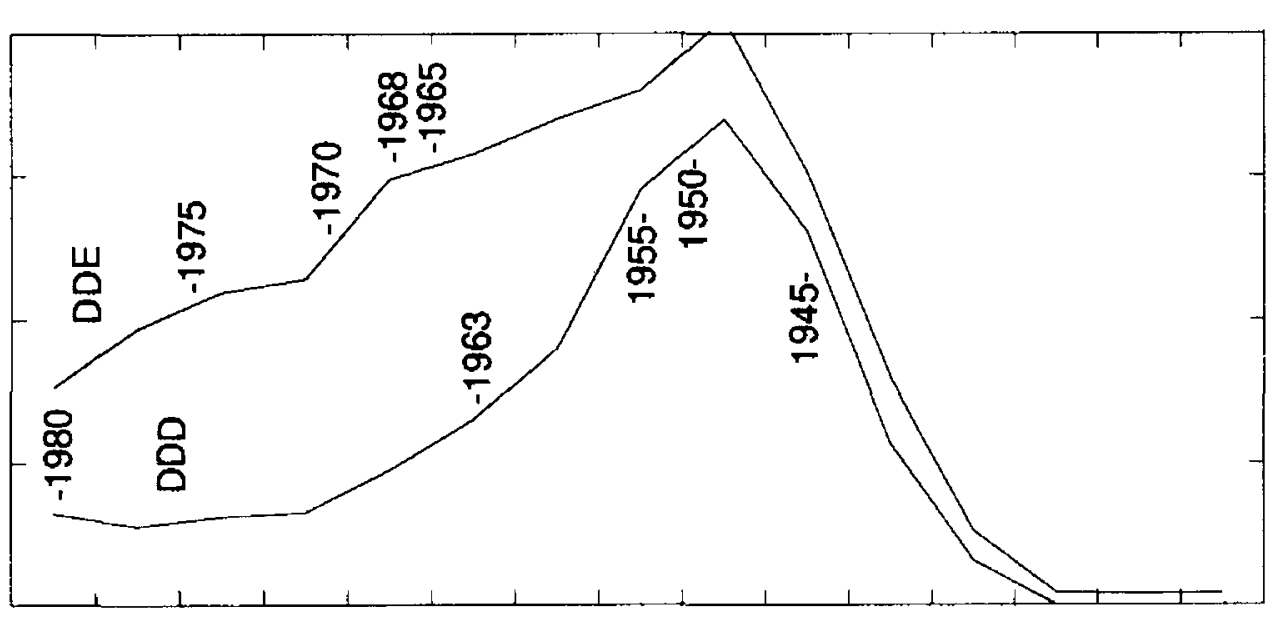

$\underline{0}$

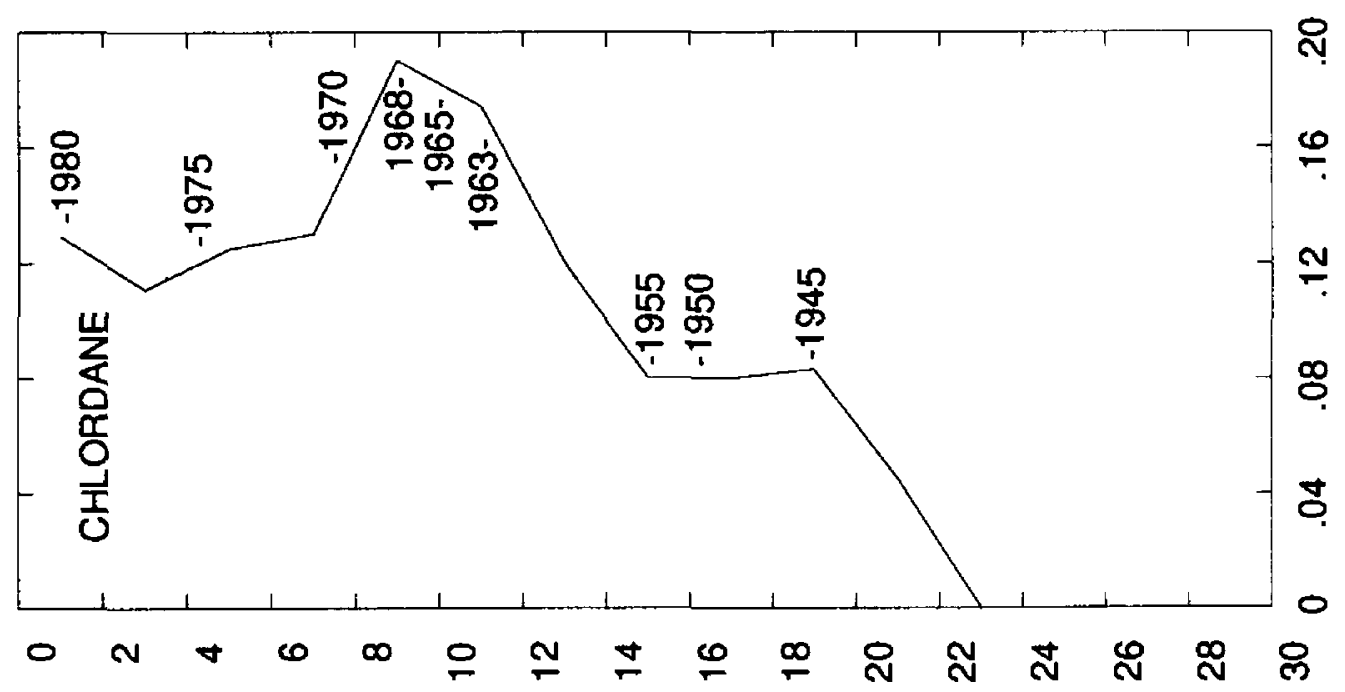

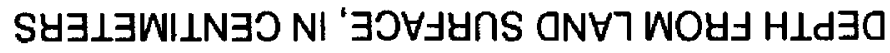


Table 5. Concentrations of organochlorine compounds on unsorted streambed materials of streams in Chester County, Pennsylvania, October 1985 through November 1987

[All values are in micrograms per kilogram; <, less than]

\begin{tabular}{|c|c|c|c|c|c|c|c|c|c|c|}
\hline $\begin{array}{c}\text { Site } \\
\text { number }\end{array}$ & Date & $\begin{array}{l}\text { Aldrin, } \\
\text { total }\end{array}$ & $\begin{array}{c}\text { Chlordane, } \\
\text { total }\end{array}$ & $\begin{array}{l}\text { DDD, } \\
\text { total }\end{array}$ & $\begin{array}{l}\mathrm{DDE}, \\
\text { total }\end{array}$ & $\begin{array}{l}\text { DDT, } \\
\text { total }\end{array}$ & $\begin{array}{l}\text { Dieldnin, } \\
\text { total }\end{array}$ & $\begin{array}{c}\text { Endosulfan, } \\
\text { total }\end{array}$ & $\begin{array}{l}\text { Endrin, } \\
\text { total }\end{array}$ & $\begin{array}{l}\text { PCB, } \\
\text { total }\end{array}$ \\
\hline 1 & $10-09-87$ & $<0.1$ & 2.0 & 0.3 & 0.2 & $<1.0$ & $<0.1$ & $<0.1$ & $<0.1$ & 3 \\
\hline 2 & $10-07-86$ & $<.1$ & $<1.0$ & $<.2$ & .5 & $<.1$ & $<.1$ & $<.2$ & $<.1$ & $<5$ \\
\hline 3 & $10-08-86$ & $<.1$ & $<1.0$ & .3 & .4 & -- & $<.1$ & .1 & $<.1$ & $<1$ \\
\hline 4 & $10-07-85$ & $<.1$ & $<1.0$ & $<.1$ & - & $<.1$ & .1 & $<.1$ & $<.1$ & 9 \\
\hline 5 & $10-06-86$ & $<.1$ & $<1.0$ & $<.1$ & .4 & .3 & $<.1$ & .3 & $<.1$ & $<1$ \\
\hline 6 & $10-11-85$ & $<.1$ & 6.0 & .4 & 1.0 & $<1$ & .3 & $<.1$ & $<.1$ & 3 \\
\hline 10 & $10-11-85$ & $<.1$ & $<1.0$ & $<.1$ & .1 & $<.1$ & $<.1$ & $<1$ & $<.1$ & $<1$ \\
\hline 12 & $10-10-85$ & $<1$ & $<1.0$ & 3 & 4 & .4 & 4.8 & $<.1$ & .1 & $<1$ \\
\hline 13 & $10-22-86$ & $<.1$ & $<1.0$ & 1.2 & 1.1 & $<1$ & .3 & $<1$ & $<1$ & $<1$ \\
\hline 14 & $10-11-85$ & $<.1$ & 6.0 & $<.1$ & .6 & $<.1$ & .1 & $<1$ & $<.1$ & 12 \\
\hline 15 & $12-05-86$ & $<.1$ & 1.0 & $<.1$ & .2 & $<.1$ & .1 & $<.1$ & $<.1$ & 3 \\
\hline 16 & $10-09-85$ & $<.1$ & 5.0 & $<.1$ & $<.1$ & $<.1$ & .2 & $<.1$ & $<.1$ & 5 \\
\hline 17 & $11-14-86$ & $<.1$ & $<1.0$ & .8 & 1.7 & 1.0 & 2.7 & $<.1$ & $<.1$ & 95 \\
\hline 19 & $10-09-86$ & $<.1$ & 7.0 & .1 & .3 & 2.2 & .1 & $<.1$ & $<.1$ & 7 \\
\hline 20 & $10-15-85$ & $<.1$ & 7.0 & .6 & .6 & $<.1$ & .3 & $<.1$ & $<.1$ & 5 \\
\hline 21 & $10-09-86$ & $<1$ & $<1.0$ & .1 & .1 & $<1$ & $<.1$ & $<.1$ & $<.1$ & $<1$ \\
\hline 22 & $10-15-86$ & $<1$ & 30 & .8 & 1.6 & 1.3 & .5 & $<.1$ & $<1$ & 8 \\
\hline 23 & $10-15-86$ & $<1$ & $<1.0$ & .3 & .6 & $<.1$ & 4 & $<.1$ & $<1$ & 4 \\
\hline 24 & $10-16-85$ & $<1$ & 7.0 & $<.1$ & 3 & $<1$ & .1 & $<.1$ & $<1$ & 2 \\
\hline 26 & $10-18-85$ & $<1$ & 5.0 & 36 & 22 & 61 & $<.1$ & $<1$ & $<1$ & 38 \\
\hline 27 & $11-18-86$ & $<.1$ & - & - & - & - & -- & $<.1$ & $<.1$ & 1,400 \\
\hline 28 & $10-25-85$ & $<.1$ & $<1.0$ & 6.3 & 2.8 & .4 & .1 & $<.1$ & $<.1$ & $<1$ \\
\hline 29 & $12-02-86$ & $<.1$ & $<1.0$ & 1.1 & 1.2 & 1.3 & .1 & $<.1$ & $<.1$ & 3 \\
\hline 30 & $10-25-85$ & $<.1$ & $<1.0$ & - & .4 & $<.1$ & $<.1$ & $<.1$ & $<.1$ & $<1$ \\
\hline 31 & $10-28-86$ & $<.1$ & 29 & 3.2 & 7.4 & .8 & .9 & $<.1$ & $<.1$ & $<1$ \\
\hline 32 & $10-17-85$ & $<.1$ & 1.0 & .8 & 1.0 & 3.1 & $<.1$ & $<.1$ & $<.1$ & $<1$ \\
\hline 33 & $11-20-86$ & $<1$ & 4.0 & 3.1 & 4.8 & 3.8 & 1.2 & $<.1$ & 3 & 3 \\
\hline 34 & $10-24-85$ & $<1$ & $<1.0$ & .1 & $<.1$ & 2 & $<1$ & $<1$ & $<.1$ & $<1$ \\
\hline 36 & $10-21-85$ & $<.1$ & $<1.0$ & .1 & 2 & $<1$ & $<.1$ & $<.1$ & $<1$ & $<1$ \\
\hline 37 & $11-17-86$ & $<.1$ & $<1.0$ & .2 & .3 & $<1$ & 6 & $<1$ & $<.1$ & 6 \\
\hline 38 & $10-22-85$ & $<.1$ & 3.0 & .6 & .2 & $<.1$ & .1 & $<.1$ & $<.1$ & 11 \\
\hline 39 & $11-03-86$ & $<.1$ & 32 & 4.4 & 4.1 & 1.3 & 3.2 & .2 & $<.1$ & 14 \\
\hline 40 & $10-30-85$ & $<.1$ & 3.0 & 3.6 & 2.5 & $<.1$ & $<.1$ & $<.1$ & $<.1$ & 6 \\
\hline 42 & $10-23-85$ & $<.1$ & $<1.0$ & $<.1$ & .2 & $<.1$ & $<.1$ & $<.1$ & $<.1$ & $<1$ \\
\hline 44 & $10-31-85$ & $<.1$ & 4.0 & .4 & $<.1$ & $<.1$ & .3 & $<.1$ & $<.1$ & 40 \\
\hline 45 & $10-30-86$ & $<.1$ & 4.0 & .6 & 2.1 & $<1$ & .7 & $<1$ & $<.1$ & $<1$ \\
\hline 46 & $10-29-85$ & $<, 1$ & $<1.0$ & $<.1$ & $<1$ & $<.1$ & $<1$ & $<.1$ & $<1$ & $<1$ \\
\hline 47 & $10-29-86$ & $<.1$ & $<1.0$ & 4 & - & $<.1$ & .4 & $<1$ & $<.1$ & 3 \\
\hline 48 & $10-29-86$ & 1 & 1.0 & 3 & 1.8 & $<1$ & .4 & $<1$ & $<.1$ & $<1$ \\
\hline 49 & $11-16-87$ & $<10$ & 13 & 3 & $<10$ & $<10$ & 8 & $<1$ & $<1$ & 540 \\
\hline 50 & $10-09-85$ & $<.1$ & 5.0 & 1.7 & 1.7 & 3.2 & .1 & $<.1$ & $<.1$ & 18 \\
\hline 51 & $10-16-86$ & $<.1$ & 110 & 5.0 & 2.1 & 1.2 & .6 & $<.1$ & $<.1$ & 73 \\
\hline
\end{tabular}


Table 5. Concentrations of organochlorine compounds on unsorted streambed materials of streams in Chester County, Pennsylvania, October 1985 through November 1987-Continued

[All values are in micrograms per kilogram; <, less than]

\begin{tabular}{|c|c|c|c|c|c|c|c|c|c|}
\hline $\begin{array}{c}\text { Site } \\
\text { number }\end{array}$ & Date & $\begin{array}{l}\text { PCN, } \\
\text { total }\end{array}$ & $\begin{array}{l}\text { Heptachlor, } \\
\text { total }\end{array}$ & $\begin{array}{l}\text { Heptachlor } \\
\text { epoxide, } \\
\text { total }\end{array}$ & $\begin{array}{l}\text { Lindane, } \\
\text { total }\end{array}$ & $\begin{array}{l}\text { Methoxychlor, } \\
\text { total }\end{array}$ & $\begin{array}{l}\text { Mirex, } \\
\text { total }\end{array}$ & $\begin{array}{l}\text { Perthane, } \\
\text { total }\end{array}$ & $\begin{array}{l}\text { Toxaphene, } \\
\text { total }\end{array}$ \\
\hline 1 & $10-09-87$ & $<1.0$ & $<0.1$ & $<0.1$ & $<0.1$ & 2.4 & $<0.1$ & $<1.00$ & $<10$ \\
\hline 2 & $10-07-86$ & $<1.0$ & $<.1$ & $<.1$ & $<.1$ & $<.1$ & $<.1$ & $<1.00$ & $<10$ \\
\hline 3 & $10-08-86$ & $<1.0$ & $<.1$ & 3.8 & $<.1$ & $<.1$ & $<.1$ & $<1.00$ & $<10$ \\
\hline 4 & $10-07-85$ & $<1.0$ & $<.1$ & $<.1$ & $<.1$ & $<.1$ & $<.1$ & $<1.00$ & $<10$ \\
\hline 5 & $10-06-86$ & $<1.0$ & $<.1$ & $<.1$ & $<.1$ & $<.1$ & .2 & $<1.00$ & $<10$ \\
\hline 6 & $10-11-85$ & $<1.0$ & $<.1$ & .2 & $<1$ & $<1$ & $<.1$ & $<1.00$ & $<10$ \\
\hline 10 & $10-11-85$ & $<1.0$ & $<.1$ & $<1$ & $<1$ & $<1$ & $<1$ & $<1.00$ & $<10$ \\
\hline 12 & $10-10-85$ & $<1.0$ & $<.1$ & .4 & $<1$ & $<1$ & $<.1$ & $<1.00$ & $<10$ \\
\hline 13 & $10-22-86$ & $<1.0$ & $<.1$ & $<1$ & .1 & $<.1$ & $<.1$ & $<1.00$ & $<10$ \\
\hline 14 & $10-11-85$ & $<1.0$ & $<.1$ & .1 & $<1$ & $<.1$ & $<.1$ & $<1.00$ & $<10$ \\
\hline 15 & $12-05-86$ & $<1.0$ & $<.1$ & $<.1$ & $<.1$ & $<.1$ & $<.1$ & $<1.00$ & $<10$ \\
\hline 16 & $10-09-85$ & $<1.0$ & $<.1$ & .1 & $<.1$ & $<.1$ & $<.1$ & $<1.00$ & $<10$ \\
\hline 17 & $11-14-86$ & $<1.0$ & $<.1$ & $<.1$ & $<.1$ & $<.1$ & $<.1$ & $<1.00$ & $<10$ \\
\hline 19 & $10-09-86$ & $<1.0$ & $<.1$ & $<.1$ & $<.1$ & $<.1$ & .7 & $<1.00$ & $<10$ \\
\hline 20 & $10-15-85$ & $<1.0$ & $<.1$ & .4 & .1 & $<.1$ & $<.1$ & $<1.00$ & $<10$ \\
\hline 21 & $10-09-86$ & $<1.0$ & $<.1$ & $<.1$ & $<.1$ & $<.1$ & $<.1$ & $<1.00$ & $<10$ \\
\hline 22 & $10-15-86$ & $<1.0$ & $<1$ & .1 & .1 & $<.1$ & $<.1$ & $<1.00$ & $<10$ \\
\hline 23 & $10-15-86$ & $<1.0$ & $<.1$ & .2 & $<.1$ & $<1$ & $<.1$ & $<1.00$ & $<10$ \\
\hline 24 & $10-16-85$ & $<1.0$ & $<.1$ & 1 & .4 & $<.1$ & $<1$ & $<1.00$ & $<10$ \\
\hline 26 & $10-18-85$ & 1.0 & $<.1$ & $<1$ & .3 & $<1$ & $<1$ & $<1.00$ & $<10$ \\
\hline 27 & $11-18-86$ & $<1.0$ & $<.1$ & $<.1$ & $<.1$ & $<.1$ & $<.1$ & - & $<10$ \\
\hline 28 & $10-25-85$ & $<1.0$ & $<.1$ & $<.1$ & $<.1$ & $<.1$ & $<.1$ & $<1.00$ & $<10$ \\
\hline 29 & $12-02-86$ & $<1.0$ & $<.1$ & $<.1$ & $<.1$ & $<.1$ & $<.1$ & $<1.00$ & $<10$ \\
\hline 30 & $10-25-85$ & $<1.0$ & $<.1$ & $<.1$ & $<.1$ & $<.1$ & $<.1$ & $<1.00$ & $<10$ \\
\hline 31 & $10-28-86$ & $<1.0$ & .5 & $<.1$ & $<.1$ & $<.1$ & $<.1$ & $<1.00$ & $<10$ \\
\hline 32 & $10-17-85$ & $<1.0$ & $<.1$ & .1 & $<1$ & $<1$ & $<1$ & $<1.00$ & $<10$ \\
\hline 33 & $11-20-86$ & $<1.0$ & $<.1$ & .1 & $<.1$ & $<.1$ & $<1$ & $<1.00$ & $<10$ \\
\hline 34 & $10-24-85$ & $<1.0$ & $<.1$ & $<1$ & $<.1$ & $<.1$ & $<.1$ & $<1.00$ & $<10$ \\
\hline 36 & $10-21-85$ & $<1.0$ & $<.1$ & $<.1$ & $<.1$ & $<.1$ & $<.1$ & $<1.00$ & $<10$ \\
\hline 37 & $11-17-86$ & $<1.0$ & $<.1$ & $<.1$ & $<.1$ & $<.1$ & $<.1$ & $<1.00$ & $<10$ \\
\hline 38 & $10-22-85$ & $<1.0$ & $<.1$ & .1 & $<.1$ & $<.1$ & $<.1$ & $<1.00$ & $<10$ \\
\hline 39 & $11-03-86$ & $<1.0$ & $<.1$ & $<.1$ & .2 & .2 & $<.1$ & $<1.00$ & $<10$ \\
\hline 40 & $10-30-85$ & $<1.0$ & $<.1$ & $<.1$ & $<.1$ & $<.1$ & $<.1$ & $<1.00$ & $<10$ \\
\hline 42 & $10-23-85$ & $<1.0$ & $<.1$ & $<.1$ & $<.1$ & $<.1$ & $<.1$ & $<1.00$ & $<10$ \\
\hline 44 & $10-31-85$ & $<1.0$ & $<.1$ & $<.1$ & $<.1$ & $<.1$ & $<.1$ & $<1.00$ & $<10$ \\
\hline 45 & $10-30-86$ & $<1.0$ & $<1$ & .1 & $<1$ & $<.1$ & $<.1$ & $<1.00$ & $<10$ \\
\hline 46 & $10-29-85$ & $<1.0$ & $<1$ & $<1$ & $<.1$ & $<1$ & $<1$ & $<1.00$ & $<10$ \\
\hline 47 & $10-29-86$ & $<1.0$ & $<.1$ & $<.1$ & $<.1$ & $<1$ & $<1$ & $<1.00$ & $<10$ \\
\hline 48 & $10-29-86$ & $<1.0$ & $<.1$ & $<.1$ & $<.1$ & $<.1$ & $<.1$ & $<1.00$ & $<10$ \\
\hline 49 & $11-16-87$ & $<1.0$ & $<10$ & $<.1$ & $<.1$ & 13 & $<10$ & $<1.00$ & $<10$ \\
\hline 50 & $10-09-85$ & $<1.0$ & .1 & .1 & $<.1$ & $<.1$ & $<.1$ & $<1.00$ & $<10$ \\
\hline 51 & $10-16-86$ & $<1.0$ & .1 & .1 & 1.0 & $<.1$ & $<.1$ & $<1.00$ & $<10$ \\
\hline
\end{tabular}


Because compound concentrations in these bulk stream-bottom samples can be expected to be complicated by variation in sample organic-carbon concentrations, only concentrations equal to or greater than $15 \mu \mathrm{g} / \mathrm{kg}$ were considered enriched for this study. Comparison of all compound concentrations by use of probability plots according to the methods of Velz (1970) also suggests that concentrations greater than about 15 to $20 \mu \mathrm{g} / \mathrm{kg}$ can be considered enriched over background. Table 6 summarizes results for compounds detected at greater than $15 \mu \mathrm{g} / \mathrm{kg}$.

Only one site (site 22) had both a bottom-material sample with the concentration of chlordane exceeding $15 \mu \mathrm{g} / \mathrm{kg}$ and an analysis of drainage-area land use. This drainage area had the second highest residential land use (greater than 74 percent) and low agricultural land use ( 0 percent), suggesting that residential land use is, or has been, the most significant source of chlordane, possibly for termite control. Moore (1987, p. 28) reports that chlordane also was used by the mushroom industry in Chester County.

Site 26 (East Branch Red Clay Creek) was the only site having combined DDT, DDD, and DDE concentrations in bottom materials exceeding $15 \mu \mathrm{g} / \mathrm{kg}$. Although no land-use data were available, the high concentrations at this site are consistent with other data suggesting heavy past or current use of DDT throughout the Red Clay Creek Basin (Cindy Rice, U.S. Fish and Wildlife Service, written commun., 1992). Unfortunately, comparisons could not be made to site 27 (West Branch Red Clay Creek) because elevated concentrations of PCB $(1,400 \mu \mathrm{g} / \mathrm{hg})$ at this site interfered with pesticide determinations.

Bottom-material samples from seven sites had PCB concentrations exceeding $15 \mu \mathrm{g} / \mathrm{kg}$, but only five sites had analyses of drainage-area land use. The drainage area of four of these sites (sites 17, 44,49, and 50) were among the six having the highest combined industrial and commercial land uses in 1987 (ranging from 7 to 26 percent). Although the drainage area of site 27 did not have high industrial and commercial land use, the extremely high PCB concentrations may have been caused by reported industrial contamination to the West Branch Red Clay Creek at Kennett Square, Pa. (Roy F. Weston, Inc., 1988, P. 3-33 to 3-36).

Three bottom-material samples from sites with drainage area land-use data (sites 5, 21, and 23) had lower concentrations of organochlorine compounds than the samples from upstream sites (see table 7). The drainage areas for the downstream sites all experienced greater than 20 percent residential growth between 1967-87, suggesting that construction activities between each pair of sites may contribute sediments that have lower pesticide concentration than do the older sediments of the streams. 
Table 6. Concentrations of organochlorine compounds exceeding or equalling 15 micrograms per kilogram on unsorted streambed materials in Chester County, Pa., October 1985 through November 1987

[--, concentration did not equal or exceed 15 micrograms per kilogram]

\begin{tabular}{cccc}
\hline $\begin{array}{c}\text { Site } \\
\text { number }\end{array}$ & Chlordane & $\begin{array}{c}\text { DDT, DDD, } \\
\text { and DDE }\end{array}$ & PCB \\
\hline${ }_{117}^{1}$ & -- & -- & 95 \\
122 & 30 & - & -- \\
26 & -- & 119 & 38 \\
$1_{2}$ & -- & -- & 1,400 \\
31 & 29 & -- & - \\
39 & 32 & -- & -- \\
144 & -- & -- & 40 \\
$1_{49}$ & -- & -- & 540 \\
150 & -- & -- & 18 \\
51 & 110 & - & 73 \\
\hline
\end{tabular}

${ }^{1} 1967$ and 1987 land-use data available for the drainage area of this site.

Table 7. Comparison of pesticide concentrations at paired sites with increasing residential land use [Concentrations are in micrograms per kilogram; <, less than]

\begin{tabular}{lcrrrr}
\multicolumn{1}{c}{$\begin{array}{c}\text { Sample } \\
\text { location }\end{array}$} & Chlordane & $\begin{array}{c}\text { Combined } \\
\text { DDT, DDD, } \\
\text { and DDE }\end{array}$ & PCB & $\begin{array}{c}\text { Heptachlor } \\
\text { epoxide }\end{array}$ & Methoxychlor \\
\hline $\begin{array}{l}\text { Pickering Creek } \\
\text { Upstream from site 5 }\end{array}$ & 2 & 0.5 & 9 & 3.8 & 2.4 \\
$\quad \begin{array}{l}\text { Site 5 } \\
\text { Ridley Creek }\end{array}$ & $<1$ & .7 & $<1$ & $<.1$ & $<.1$ \\
$\quad$ Upstream from site 21 & 7 & 1.2 & 5 & .4 & $<.1$ \\
$\quad$ Site 21 & $<1$ & .2 & $<1$ & $<.1$ & $<.1$ \\
East Branch Chester Creek & & & & & \\
$\quad$ Upstream from site 23 & 30 & 2.9 & 8 & .1 & $<.1$ \\
Site 23 & $<1$ & $<.1$ & 4 & .2 & $<.1$ \\
\hline
\end{tabular}




\section{BENTHIC-INVERTEBRATE COMMUNITIES}

Benthic-invertebrate communities were sampled annually in autumn. Samples were collected in riffles at each site by collecting 10 rocks between 45 and $90 \mathrm{~mm}$ in diameter. A Lium Sampler (Britton and Greeson, 1988, pp. 280-281) having a $210 \mu \mathrm{m}$ mesh screen was used to collect the samples. Moore (1987) discusses this sampling method and its comparability to other techniques in greater detail.

Diversities of the invertebrate communities were determined for each sample by calculating Brillouin's diversity index (Brillouin, 1962). This index is commonly used by aquatic ecologists and, when samples are only a representative part of a larger, undefined community, this index most appropriately represents community diversity (Pielou, 1969; Kaesler and Herricks, 1976; and Zand, 1976). All organisms were identified to the genus level for the entire study period except for midges (Chironomidae), which were identified to only family level for the 1970-74 and 1981-88 periods. In order to ensure comparability for this study, all diversity indexes were calculated on the basis of midge identification to family level. Brillouin's diversity indexes for each sample for 1970-88 are given in the appendix. Diversity indexes as a function of time also are given in graphic form for each site. The 1978 data were omitted from the tables, time plots, and trend analyses because variations in the sampling procedures made comparisons to the other data inappropriate. Supplementary information also given in the appendix includes numbers of organisms and taxa and calculations of minimum diversity, maximum diversity, and evenness. Moore (1987, p. 11) gives detailed descriptions of these calculations. Generally, higher diversities were directly related to higher numbers of organisms and higher numbers of taxa at the genus and family levels, but not at the order level.

A nonparametric, distribution-free statistical test for monotonic trend with time was used to detect trends in the diversities at each of 46 sites. Magnitude of trend in the data was determined by the Kendall slope estimator (Hirsch and others, 1982). Sites previously dropped from the network because habitat differences resulted in data that could not be compared to other network sites (sites 25 and 41 ) and sites having only recent diversity data (sites 16,39, and 51) were not included in the analysis. Trend tests and estimates of the slope of the linear trends are presented in table 8 . The diversity of benthic-invertebrate communities increased at 45 of 46 sites. The upward trends were significant at the 99-percent confidence level at 30 sites, 95- to 98-percent confidence level at 9 sites, and 90- to 94-percent confidence level at 3 sites (table 8). The trends in diversity indexes at sites $7,28,31$, and 47 were not statistically significant. Sites 3 and 26, which exhibited downward diversity-index trends prior to 1981 (Moore, 1987), show statistically significant upward trends. 
Table 8. Values of slope, tau, $p$, and level of confidence from seasonal Kendall test of diversity index

$[--$, trend not statistically significant at the 90-percent confidence level;

Tau, measures the degree of correlation-the lower the tau value, the lower the correlation; $p$, measures the significance of the trend-the higher the $p$ value, the higher the probability of error]

\begin{tabular}{|c|c|c|c|c|}
\hline $\begin{array}{c}\text { Site } \\
\text { number }\end{array}$ & $\begin{array}{l}\text { Kendall } \\
\text { slope } \\
\text { estimator }\end{array}$ & Tau & $p$ & $\begin{array}{l}\text { Level of } \\
\text { confidence } \\
\text { of significant } \\
\text { trends } \\
\text { (percent) }\end{array}$ \\
\hline 1 & 0.08 & 0.72 & 0.00 & 99 \\
\hline 2 & .08 & .43 & .02 & 98 \\
\hline 3 & .06 & .42 & .03 & 97 \\
\hline 4 & .10 & .67 & .001 & 99 \\
\hline 5 & .09 & .55 & .01 & 99 \\
\hline 6 & .16 & .78 & .00 & 99 \\
\hline 7 & .14 & .33 & .18 & -- \\
\hline 8 & .08 & .44 & .09 & 91 \\
\hline 9 & .11 & .64 & .01 & 99 \\
\hline 10 & .09 & .64 & .00 & 99 \\
\hline 11 & .13 & .72 & .01 & 99 \\
\hline 12 & .08 & .68 & .00 & 99 \\
\hline 13 & .06 & .32 & .09 & 91 \\
\hline 14 & .06 & .37 & .05 & 95 \\
\hline 15 & .07 & .43 & .02 & 98 \\
\hline 17 & .13 & .85 & .00 & 99 \\
\hline 18 & .13 & .56 & .03 & 97 \\
\hline 19 & .09 & .50 & .01 & 99 \\
\hline 20 & .11 & .66 & .00 & 99 \\
\hline 21 & .09 & .56 & .00 & 99 \\
\hline 22 & .09 & .57 & .00 & 99 \\
\hline 23 & .15 & .70 & .00 & 99 \\
\hline 24 & .12 & .67 & .00 & 99 \\
\hline 26 & .08 & .39 & .05 & 95 \\
\hline 27 & .01 & .58 & .00 & 99 \\
\hline 28 & .00 & .01 & 1.00 & -- \\
\hline 29 & .12 & .66 & .00 & 99 \\
\hline 30 & .10 & .70 & .00 & 99 \\
\hline 31 & .08 & .31 & .11 & -- \\
\hline 32 & .07 & .47 & .02 & 98 \\
\hline 33 & .10 & .68 & .00 & 99 \\
\hline 34 & .12 & .59 & .00 & 99 \\
\hline 35 & .10 & .41 & .07 & 93 \\
\hline 36 & .08 & .54 & .00 & 99 \\
\hline 37 & .09 & .47 & .01 & 99 \\
\hline 38 & .14 & .71 & .00 & 99 \\
\hline 40 & .15 & .78 & .00 & 99 \\
\hline 42 & .12 & .62 & .00 & 99 \\
\hline 43 & .21 & .71 & .02 & 98 \\
\hline 44 & .08 & .55 & .01 & 99 \\
\hline 45 & .07 & .47 & .02 & 99 \\
\hline 46 & .12 & .65 & .00 & 99 \\
\hline 47 & .04 & .35 & .11 & $\cdots$ \\
\hline 48 & .07 & .46 & .02 & 98 \\
\hline 49 & .10 & .69 & .00 & 99 \\
\hline 50 & .13 & .88 & .00 & 99 \\
\hline
\end{tabular}




\section{RELATIONS AMONG LAND USE, BENTHIC-INVERTEBRATE COMMUNITIES, AND ORGANOCHLORINE COMPOUNDS}

Streamflow data were examined to determine if extreme hydrologic conditions would have significantly affected invertebrate communities for any sampling periods. Available discharge records from Brandywine, Darby, and French Creeks were examined for streamflows less than the 7-day, 10-year low flow and the two highest peak flows occurring up to 3 months prior to or during sampling. These extreme flows were compared to invertebratecommunity diversities and numbers of organisms. The comparisons showed no consistent effects that could be expected to overwhelm other factors, such as land use, for any sampling periods.

The trends in community diversities and changes in land use were compared. The 1988 land-use data for 26 drainage areas primarily show increases in residential land use and decreases in agricultural land use since 1967. Biological data collected from sites in these drainage areas show positive trends in the diversity indices for the period 1970-88. These data were analyzed by use of contingency tables to measure any possible relation between the biological trends and land-use changes. The contingency analyses were based on the frequency with which a large percentage change in land use and a high Kendall slope estimator occurred together in a basin.

The contingency analyses showed that the relation between the Kendall slope estimator and the increases in residential land use of 12 percent or greater was significant at the 95percent confidence level. The phi-coefficient (the correlation coefficient calculated on the observations in the contingency table) was 0.43 , which shows a moderate dependence. Increases in residential land use greater than or equal to 12 percent occurred in 18 of the 26 drainage areas with land-use data in Chester County.

The contingency analyses also showed that the relation between the Kendall slope estimators and decreases in agricultural land use of 5 percent or greater was significant at the 95-percent confidence level. The phi-coefficient was 0.39 , which again shows a moderate dependence. Decreases in cropland greater than or equal to 5 percent occurred in 23 of the 26 drainage areas.

Data from the nested systems (French, Pickering, Ridley, and East Branch Chester Creeks) suggest no refinements to conclusions drawn from the entire data base. All sites showed similar degrees of improvement in the diversity of benthic communities. 
The relation between community diversities and concentrations of organochlorine compounds in bottom sediments also was analyzed by use of contingency tables.

Concentrations of chlordane, $\mathrm{PCB}^{\prime} \mathrm{s}$, and DDT plus its breakdown products were totaled for use in the analyses and compared to those diversities for biological samples collected in the same year. The contingency tables showed that the relation between diversity indexes of less than 2.25 and concentrations of organochlorine compounds greater than $45 \mu \mathrm{g} / \mathrm{kg}$ was significant at the 95-percent confidence level. The phi-coefficient was 0.37 , which showed a moderate dependence. Concentrations of organochlorine compounds were greater than $45 \mu \mathrm{g} / \mathrm{kg}$ at 5 of the 42 sites (sites 17,26,27,49, and 51).

Comparisons of the magnitude of organochlorine-compound concentrations to the ranking of the diversities suggest that pesticide residues could influence the benthic communities more than PCB residues influence them. The maximum concentrations of DDT plus its breakdown products and chlordane $(119$ and $110 \mu \mathrm{g} / \mathrm{kg}$, respectively) were at sites 26 and 51. The concentration of PCB residues at site $27(1,400 \mu \mathrm{g} / \mathrm{kg})$ was so high that it interfered with the detection of other pesticides. The diversities associated with these high concentrations were in the lowest quartile of all diversities (less than 2.39). In contrast, concentrations of PCB at sites 17 and 49 ( 95 and $540 \mu \mathrm{g} / \mathrm{kg}$, respectively) were associated with diversities greater than 3.0 (median diversity).

Overall, the contingency-table analyses show relations that support several possible factors or combination of factors affecting the invertebrate communities. Sediment produced by new residential development might be less than that produced by the replaced agricultural activities, causing less stress on the communities. Decreases in agricultural land use and (or) changing pesticide use might translate into less pesticide influx to streams, also causing less stress on communities. Finally, sediment from new residential development might have lower pesticide concentrations associated with it than sediment from agricultural land does, resulting in dilution of pesticides in the streambed materials where the benthic communities reside. However, the moderate degree of dependence for these relations indicates that landuse changes and organochlorine compounds are probably only two of several factors that might cause the improvements in benthic-invertebrate communities observed in the streams studied. Site-specific studies would be required to verify the cause and effect relations suggested by this study or to identify other significant factors affecting the communities. 


\section{SUMMARY AND CONCLUSIONS}

Land use was analyzed for the drainage areas of 26 stream sites that cover about 30 percent of Chester County. The most significant land-use changes during 1967-87 were decreased agricultural land use and increased residential, commercial, and industrial land use.

Cores of lakebed sediments at the site of Icedale Lake (a drained reservoir on West Branch Brandywine Creek) were collected to evaluate past influx of organochlorine pesticides and PCB's. Residues of DDD and DDE indicate that DDT was the first organochlorine insecticide entering the stream; concentrations peaked in the late 1940's and early 1950's. After this time, the influx of DDT decreased and those of chlordane and dieldrin increased. The influxes of these two insecticides peaked near the late-1960's, corresponding with reported national peak farm usage. Influx of PCB's seemed to be somewhat erratic; concentrations peaked from the late 1940 's through the late 1960's. It is not known if any of the PCB influxes were associated with pesticide use. The core data suggest that influx of chlordane, dieldrin, and PCB's were greatest before the start of the biological monitoring program and decreased through the early 1980's, supporting the hypothesis of decreased pesticide use suggested by Sloto (1987).

Samples of stream-bottom material were collected at 42 sites in the study area from October 1985 through November 1987 and analyzed for organochlorine pesticides and PCB's. Organochlorine compounds were detected in streambed materials at 41 of the 42 sites sampled. The most enriched compounds (greater than $15 \mu \mathrm{g} / \mathrm{kg}$ ) were PCB's, chlordane, and DDT plus its breakdown products. Methoxychlor was detected only in drainage areas with commercial land use greater than 6 percent. Chlordane concentrations exceeding $15 \mu \mathrm{g} / \mathrm{kg}$ were detected at four sites, and the only site of these four with drainage area land-use data had high residential land use ( 74 percent) and low ( 0 percent) agricultural land use. Four of the five highest $\mathrm{PCB}$ concentrations were within the six drainage areas with the highest combined industrial and commercial land use. Although the drainage area of the site with the highest PCB concentration included less than 4 percent total industrial and commercial land use, the site is located downstream of an industrial-contamination site. In the nested systems, pesticide and (or) PCB concentrations were lower at three downstream sites than they were at the upstream sites. The drainage areas of all of these sites experienced greater than 20 percent residential growth between 1967 and 1987.

Brillouin's diversity index was calculated for all biological samples for each site in Chester County. Diversity index was plotted as a function of time at each site and tested for trend by use of the seasonal Kendall test. Upward trends in Brillouin's diversity index were found at 45 of the 46 stream sites. The upward trends were significant at the 99 -percent confidence level at 30 sites, were significant at the 95- to 98-percent confidence level at 9 sites, and were significant at the 90- to 94-percent confidence level at 3 sites. Trends at only four sites were not statistically significant at the 90-percent confidence level.

Contingency-table analyses showed that upward trends in invertebrate-community diversities were associated with increases in residential land use of 12 percent or greater; and decreases in agricultural land use of 5 percent or greater. Contingency-table analyses also showed that concentrations of organochlorine compounds exceeding $45 \mu \mathrm{g} / \mathrm{kg}$ in streambottom material were associated with community diversities less than 2.25. However, the moderate degree of dependence demonstrated by the contingency analyses suggests that additional factors also affect the communities. 


\section{REFERENCES CITED}

American Society for Testing and Materials, 1987, Standard practice for high-resolution gamma-ray spectrometry of water in Annual Book of ASTM standards: Philadelphia, Pa., American Society for Testing and Materials D3649-85.

Brillouin, L., 1962, Science and information theory (2nd ed.): New York, Academic Press, $347 \mathrm{p}$.

Britton, L.J., and Greeson, P.E., eds., 1988, Methods for collection and analysis of aquatic biological and microbiological samples: U.S. Geological Survey Open-File Report 88-190, 685 p.

Callahan, M.A., Slimak, M.W., Gabel, N.W., May, I.P., Fowler, C.F., Freed, J.R., Jennings, Patricia, Durfee, R.L., Whitmore, F.C., Maestri, Bruno, Mabey, W.R., Holt, B.R., and Gould, Constance, 1979, Water-related environmental fate of 129 priority pollutants: U.S. Environmental Protection Agency, EPA-440/4-79-029 a, b.

Chester County Planning Commission, 1972, Existing land use 1972: West Chester, Pa., 1 sheet, scale 1:126,720.

-----1987, Existing land use 1987: West Chester, Pa., 1 sheet, scale 1:95,000.

Gilliom, R.J., Alexander, R.B., and Smith, R.A., 1985, Pesticides in the nation's rivers, 19751980, and implications for future monitoring: U.S. Geological Survey Water-Supply Paper 2271, 26 p.

Hirsch, R.M., Slack, J.R., and Smith, R.A., 1982, Techniques of trend analysis for monthly water-quality data: Water Resources Research, v. 18, no. 1, p. 107-121.

Horowitz, A.J., 1991, A primer on sediment-trace element chemistry (2nd ed.): Chelsea, Mich., Lewis Publishers, 136 p.

Johnsen, R.E., 1976, DDT metabolism in microbial systems: Residue Reviews, v. 61, p. 1-28.

Kaesler, R.L., and Herricks, E.E., 1976, Analysis of data from biological surveys of streamsdiversity and sample size: Water Resources Bulletin, v. 12, no. 6, p. 125-135.

Lium, B.W., 1976, Limnological data for the major streams in Chester County, Pennsylvania: U.S. Geological Survey Open-File Report (unnumbered), 219 p.

--1977, Limnological studies of the major streams in Chester County, Pennsylvania: U.S. Geological Survey Open-File Report 77-462, 37 p.

Miller, R.A.,Troxell, John, and Leopold, L.B., 1971, Hydrology of two small river basins in Pennsylvania before urbanization: U.S. Geological Survey Professional Paper 701-A, $57 \mathrm{p}$.

Moore, C.R., 1987, Determination of benthic-invertebrate indices and water-quality trends of selected streams in Chester County, Pennsylvania, 1969-80: U.S. Geological Survey Water-Resources Investigations Report 85-4177, 62 p.

---1989, Physical, chemical, and biological data for selected streams in Chester County, Pennsylvania, 1969-80: U.S. Geological Survey Open-File Report 85-686, 289 p. 


\section{REFERENCES CITED-Continued}

National Council on Radiation Protection and Measurements, 1985, A handbook of radioactivity measurement and procedures (2nd ed.): Washington, D.C., National Council on Radiation Protection Report 58, 592 p.

National Research Council, 1979, Polychlorinated biphenyls: Washington, D.C., National Academy of Sciences, $182 \mathrm{p}$.

Pielou, E.C., 1969, An introduction to mathematical ecology: New York, John Wiley, 286 p.

Ritchie, J.C., McHenry, J.R., and Gill, A.C., 1973, Dating recent reservoir sediments: Limnology and Oceanography, v. 18, no. 2, p. 254-263.

Roy F. Weston, Inc., 1988, Synoptic report on toxic substances contamination of Red Clay Creek: Delaware Department of Natural Resources and Environmental Control.

Sloto, R.A., 1987, Effect of urbanization on the water resources of eastern Chester County, Pennsylvania: U.S. Geological Survey Water-Resources Investigations Report 87-4098, $131 \mathrm{p}$.

Smith, J.A., Witkowski, P.J., and Fusillo, T.V., 1988, Manmade organic compounds in the surface waters of the United States-A review of current understanding: U.S. Geological Survey Circular 1007, 92 p.

U.S. Geological Survey, 1975-89, Water resources data for Pennsylvania, 1974-88-volume 1: U.S. Geological Survey Water-Data Reports PA-74-1 to PA-88-1 (published annually).

Velz, C.J., 1970, Applied stream sanitation: New York, John Wiley and Sons, 619 p.

Wershaw, M.J., Fishman, M.J., Grabbe, R.R., and Lowe, L.E., 1987, Methods for the determination of organic substances in water and fluvial sediments: U.S. Geological Survey Techniques of Water-Resources Investigations, book 5, chap. A3, 80 p.

Zand, S.M., 1976, Indexes associated with information theory in water quality: Water Pollution Control Federation Journal, v. 48, no. 8, p. 2026-2031. 
Appendix.-Brillouin's diversity index, maximum diversity, minimum diversity,

and relative evenness, by site 
Site 1

\begin{tabular}{rcccccc}
\hline Year & $\begin{array}{c}\text { Total } \\
\text { number of } \\
\text { organisms }\end{array}$ & $\begin{array}{c}\text { Total } \\
\text { number } \\
\text { of taxa }\end{array}$ & $\begin{array}{c}\text { Brillouin's } \\
\text { diversity } \\
\text { index (H) }\end{array}$ & $\begin{array}{c}\text { Maximum } \\
\text { diversity } \\
\text { (Hmax) }\end{array}$ & $\begin{array}{c}\text { Minimum } \\
\text { diversity } \\
\text { (Hmin) }\end{array}$ & $\begin{array}{c}\text { Evenness } \\
\text { (E) }\end{array}$ \\
\hline 1970 & 161 & 5 & 2.10 & 2.27 & 0.18 & 0.92 \\
1971 & 37 & 4 & 1.71 & 1.88 & .42 & .89 \\
1972 & 743 & 14 & 1.58 & 3.74 & .17 & .40 \\
1973 & 173 & 6 & .87 & 2.62 & .21 & .27 \\
1974 & -- & - & - & -- & - & - \\
1975 & -- & - & - & - & - & - \\
1976 & 820 & 23 & 2.60 & 4.52 & .26 & .55 \\
1977 & 1,121 & 22 & 2.49 & 4.49 & .19 & .54 \\
1979 & 94 & 11 & 2.56 & 3.37 & .69 & .70 \\
1980 & 242 & 16 & 2.76 & 3.84 & .49 & .68 \\
1981 & 1,307 & 23 & 2.80 & 4.54 & .17 & .60 \\
1982 & 2,651 & 22 & 2.64 & 4.45 & .09 & .58 \\
1983 & 2,711 & 31 & 2.78 & 4.94 & .13 & .55 \\
1984 & 1,539 & 23 & 2.78 & 4.55 & .15 & .60 \\
1985 & 760 & 31 & 3.35 & 4.91 & .38 & .66 \\
1986 & 1,096 & 32 & 3.43 & 4.93 & .29 & .68 \\
1987 & 1,438 & 25 & 2.87 & 4.63 & .17 & .61 \\
1988 & 2,731 & 29 & 3.14 & 4.82 & .12 & .64 \\
\hline
\end{tabular}

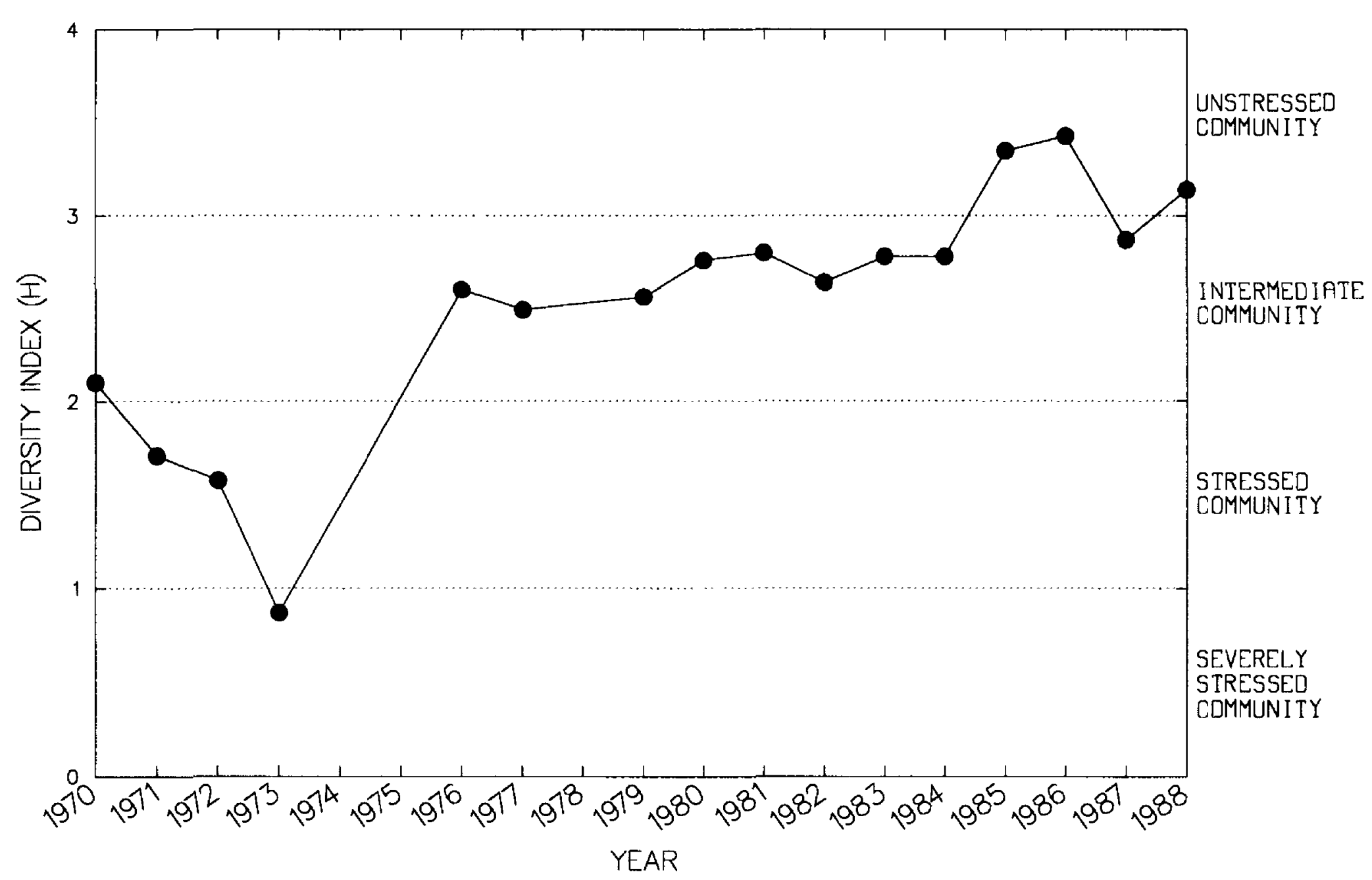


Site 2

\begin{tabular}{rcccccc}
\hline Year & $\begin{array}{c}\text { Total } \\
\text { number of } \\
\text { organisms }\end{array}$ & $\begin{array}{c}\text { Total } \\
\text { number } \\
\text { of taxa }\end{array}$ & $\begin{array}{c}\text { Brillouin's } \\
\text { diversity } \\
\text { index (H) }\end{array}$ & $\begin{array}{c}\text { Maximum } \\
\text { diversity } \\
\text { (Hmax) }\end{array}$ & $\begin{array}{c}\text { Minimum } \\
\text { diversity } \\
\text { (Hmin) }\end{array}$ & $\begin{array}{c}\text { Evenness } \\
\text { (E) }\end{array}$ \\
\hline 1970 & 84 & 7 & 2.07 & 2.60 & 0.45 & 0.75 \\
1971 & 29 & 4 & 1.72 & 1.85 & .50 & .90 \\
1972 & 413 & 17 & 2.29 & 4.01 & .34 & .53 \\
1973 & 629 & 20 & 1.01 & 4.28 & .28 & .18 \\
1974 & 173 & 13 & 1.89 & 3.58 & .51 & .45 \\
1975 & -- & -- & - & - & - & - \\
1976 & 531 & 35 & 3.34 & 4.97 & .58 & .63 \\
1977 & 190 & 17 & 3.07 & 3.89 & .63 & .75 \\
1979 & 837 & 19 & 3.19 & 3.94 & 1.35 & .71 \\
1980 & 132 & 7 & 2.13 & 2.85 & .32 & .72 \\
1981 & 745 & 20 & 2.41 & 4.26 & .24 & .54 \\
1982 & 1,088 & 26 & 3.06 & 4.72 & .23 & .63 \\
1983 & 526 & 24 & 3.80 & 4.62 & .39 & .80 \\
1984 & 1,351 & 21 & 3.17 & 4.36 & .15 & .72 \\
1985 & 598 & 28 & 3.14 & 4.73 & .42 & .63 \\
1986 & 485 & 30 & 3.44 & 4.75 & .53 & .69 \\
1987 & 170 & 18 & 2.42 & 4.04 & .73 & .51 \\
1988 & 1,341 & 24 & 3.29 & 4.60 & .18 & .70 \\
\hline
\end{tabular}

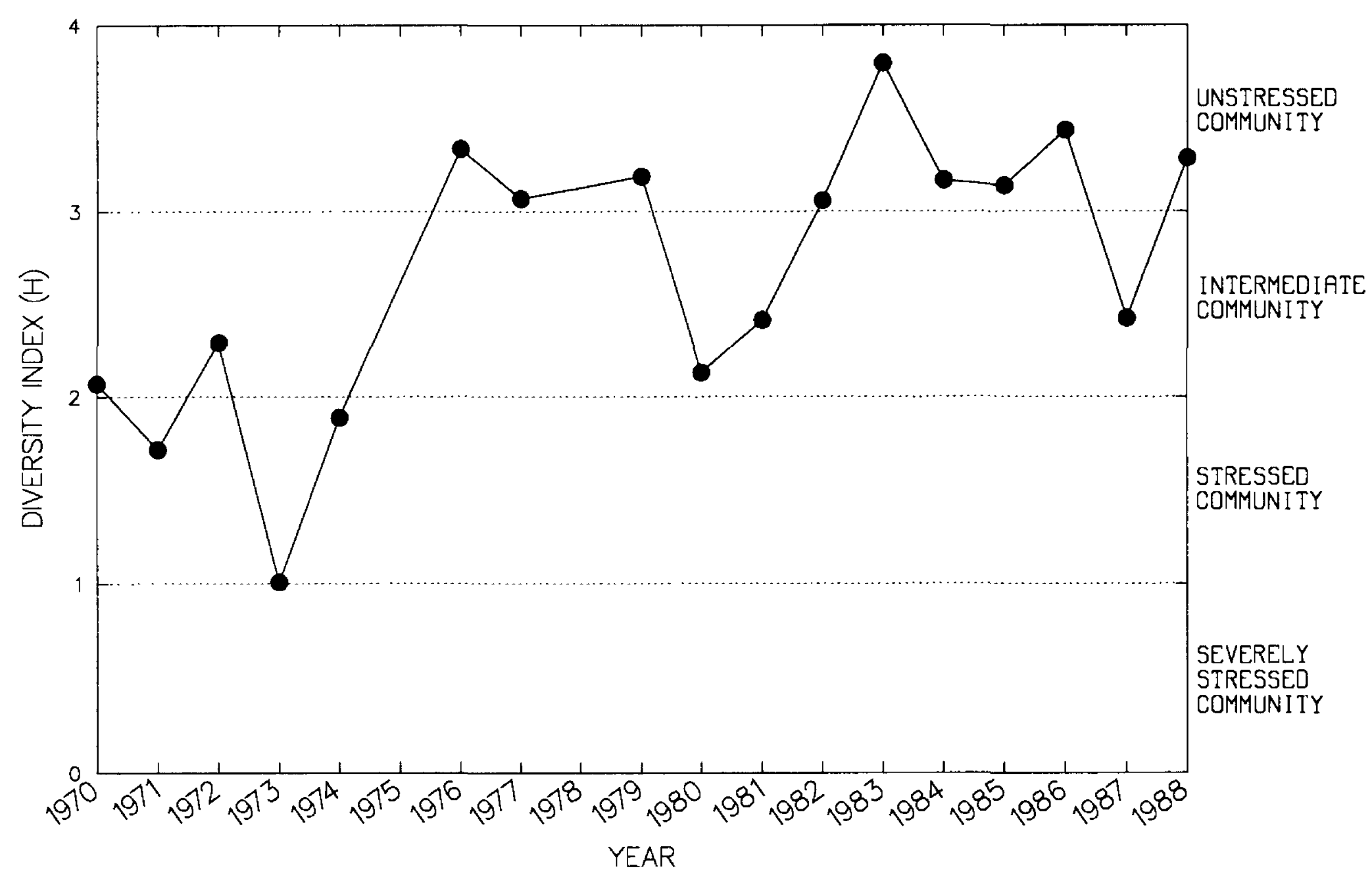


Site 3

\begin{tabular}{ccccccr}
\hline Year & $\begin{array}{c}\text { Total } \\
\text { number of } \\
\text { organisms }\end{array}$ & $\begin{array}{c}\text { Total } \\
\text { number } \\
\text { of taxa }\end{array}$ & $\begin{array}{c}\text { Brillouin's } \\
\text { diversity } \\
\text { index }(\mathrm{H})\end{array}$ & $\begin{array}{c}\text { Maximum } \\
\text { diversity } \\
\text { (Hmax) }\end{array}$ & $\begin{array}{c}\text { Minimum } \\
\text { diversity } \\
\text { (Hmin) }\end{array}$ & $\begin{array}{c}\text { Evenness } \\
\text { (E) }\end{array}$ \\
\hline 1970 & 79 & 10 & 2.60 & 3.36 & 0.71 & 0.71 \\
1971 & 71 & 7 & 2.30 & 2.62 & .52 & .85 \\
1972 & 119 & 24 & 3.26 & 4.57 & 1.31 & .60 \\
1973 & 560 & 21 & 1.87 & 4.38 & .33 & .38 \\
1974 & 128 & 14 & 2.37 & 3.57 & .70 & .58 \\
1975 & - & -- & - & - &.- & - \\
1976 & 1,660 & 27 & 2.09 & 4.74 & .17 & .42 \\
1977 & 547 & 23 & 2.27 & 4.53 & .36 & .46 \\
1979 & 47 & 13 & 2.62 & 3.48 & 1.37 & .59 \\
1980 & 1,334 & 28 & 2.14 & 4.80 & .21 & .42 \\
1981 & 1,757 & 27 & 2.72 & 4.70 & .16 & .56 \\
1982 & 2,118 & 30 & 3.17 & 4.90 & .15 & .63 \\
1983 & 931 & 25 & 3.68 & 4.58 & .25 & .79 \\
1984 & 1,394 & 24 & 3.07 & 4.52 & .17 & .66 \\
1985 & 916 & 40 & 3.63 & 5.35 & .42 & .65 \\
1986 & 1,052 & 36 & 2.67 & 5.08 & .33 & .49 \\
1987 & 1,394 & 38 & 3.34 & 5.24 & .28 & .62 \\
1988 & 1,044 & 24 & 3.35 & 4.56 & .22 & .72 \\
\hline
\end{tabular}

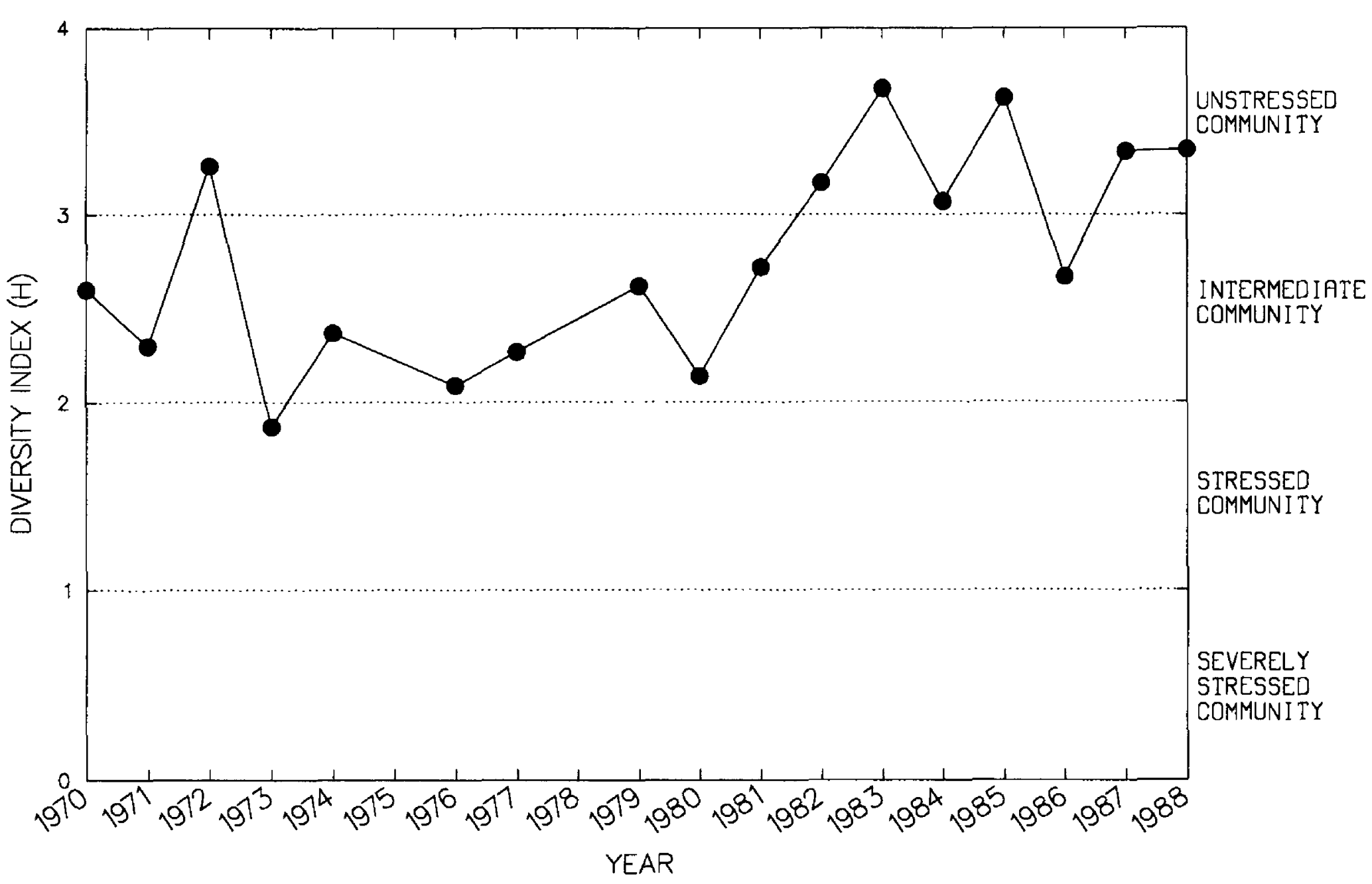


Site 4

\begin{tabular}{ccccccc}
\hline Year & $\begin{array}{c}\text { Total } \\
\text { number of } \\
\text { organisms }\end{array}$ & $\begin{array}{c}\text { Total } \\
\text { number } \\
\text { of taxa }\end{array}$ & $\begin{array}{c}\text { Brillouin's } \\
\text { diversity } \\
\text { index }(\mathrm{H})\end{array}$ & $\begin{array}{c}\text { Maximum } \\
\text { diversity } \\
\text { (Hmax) }\end{array}$ & $\begin{array}{c}\text { Minimum } \\
\text { diversity } \\
\text { (Hmin) }\end{array}$ & $\begin{array}{c}\text { Evenness } \\
\text { (E) }\end{array}$ \\
\hline 1970 & -- & -- & -- & -- & - & - \\
1971 & -- & -- & -- & -- & - & - \\
1972 & 483 & 16 & 2.16 & 3.92 & 0.28 & 0.52 \\
1973 & 103 & 9 & 1.07 & 3.08 & .52 & .21 \\
1974 & 415 & 17 & 2.27 & 4.03 & .33 & .52 \\
1975 & -- & -- & - & - & - & - \\
1976 & 740 & 26 & 2.34 & 4.66 & .32 & .47 \\
1977 & 862 & 22 & 2.29 & 4.39 & .24 & .49 \\
1979 & 232 & 19 & 2.22 & 4.08 & .61 & .47 \\
1980 & 2,864 & 22 & 3.13 & 4.43 & .08 & .70 \\
1981 & 3,650 & 32 & 2.68 & 4.96 & .10 & .53 \\
1982 & 1,885 & 31 & 3.23 & 4.97 & .17 & .64 \\
1983 & 1,306 & 27 & 3.42 & 4.72 & .21 & .71 \\
1984 & 1,947 & 26 & 3.14 & 4.72 & .14 & .66 \\
1985 & 556 & 27 & 3.26 & 4.72 & .42 & .66 \\
1986 & 2,610 & 38 & 2.93 & 5.25 & .15 & .54 \\
1987 & 2,326 & 36 & 3.34 & 5.16 & .17 & .64 \\
1988 & 4,126 & 36 & 2.99 & 5.17 & .10 & .57 \\
\hline
\end{tabular}

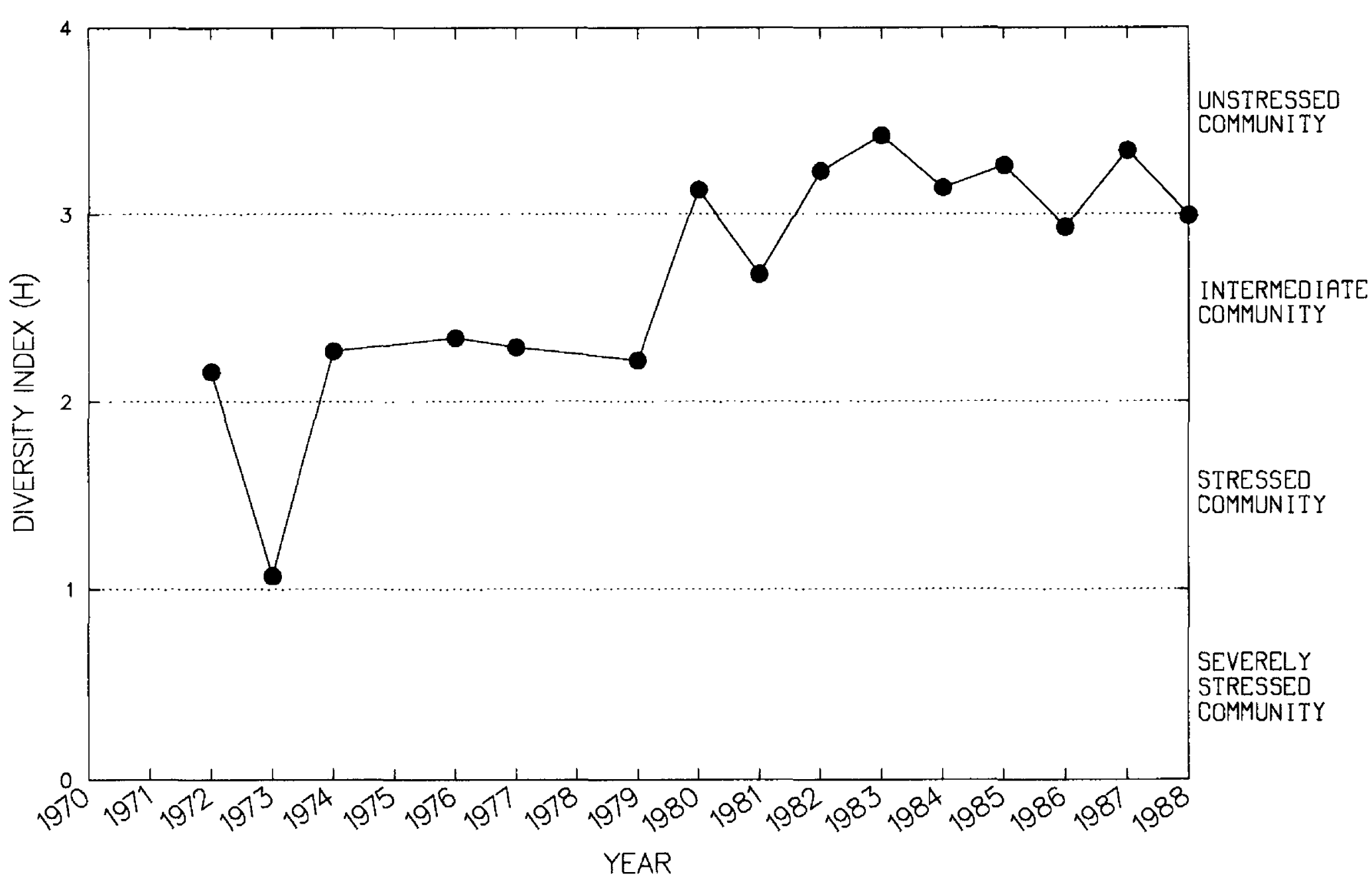


Site 5

\begin{tabular}{ccccccc}
\hline Year & $\begin{array}{c}\text { Total } \\
\text { number of } \\
\text { organisms }\end{array}$ & $\begin{array}{c}\text { Total } \\
\text { number } \\
\text { of taxa }\end{array}$ & $\begin{array}{c}\text { Brillouin's } \\
\text { diversity } \\
\text { index }(\mathrm{H})\end{array}$ & $\begin{array}{c}\text { Maximum } \\
\text { diversity } \\
\text { (Hmax) }\end{array}$ & $\begin{array}{c}\text { Minimum } \\
\text { diversity } \\
\text { (Hmin) }\end{array}$ & $\begin{array}{c}\text { Evenness } \\
\text { (E) }\end{array}$ \\
\hline 1970 & 127 & 10 & 2.34 & 3.31 & 0.49 & 0.65 \\
1971 & 7 & 2 & .73 & 1.02 & .40 & .54 \\
1972 & 241 & 17 & 2.82 & 3.93 & .52 & .68 \\
1973 & 156 & 11 & 1.76 & 3.31 & .46 & .46 \\
1974 & -- & -- & - & - & - & - \\
1975 & 375 & 17 & 2.80 & 3.95 & .36 & .68 \\
1976 & 906 & 29 & 2.41 & 4.78 & .30 & .47 \\
1977 & 316 & 23 & 2.78 & 4.51 & .57 & .56 \\
1979 & 85 & 12 & 2.10 & 3.28 & .82 & .52 \\
1980 & 520 & 20 & 3.56 & 4.19 & .33 & .84 \\
1981 & 2,062 & 32 & 2.77 & 4.98 & .17 & .54 \\
1982 & 3,230 & 39 & 3.00 & 5.30 & .14 & .56 \\
1983 & 2,167 & 38 & 3.50 & 5.18 & .19 & .66 \\
1984 & 1,506 & 32 & 3.38 & 4.92 & .22 & .67 \\
1985 & 433 & 30 & 3.32 & 4.81 & .58 & .65 \\
1986 & 1,154 & 40 & 3.46 & 5.34 & .34 & .62 \\
1987 & 2,020 & 39 & 3.55 & 5.30 & .21 & .66 \\
1988 & 2,653 & 28 & 2.83 & 4.81 & .12 & .58 \\
\hline
\end{tabular}

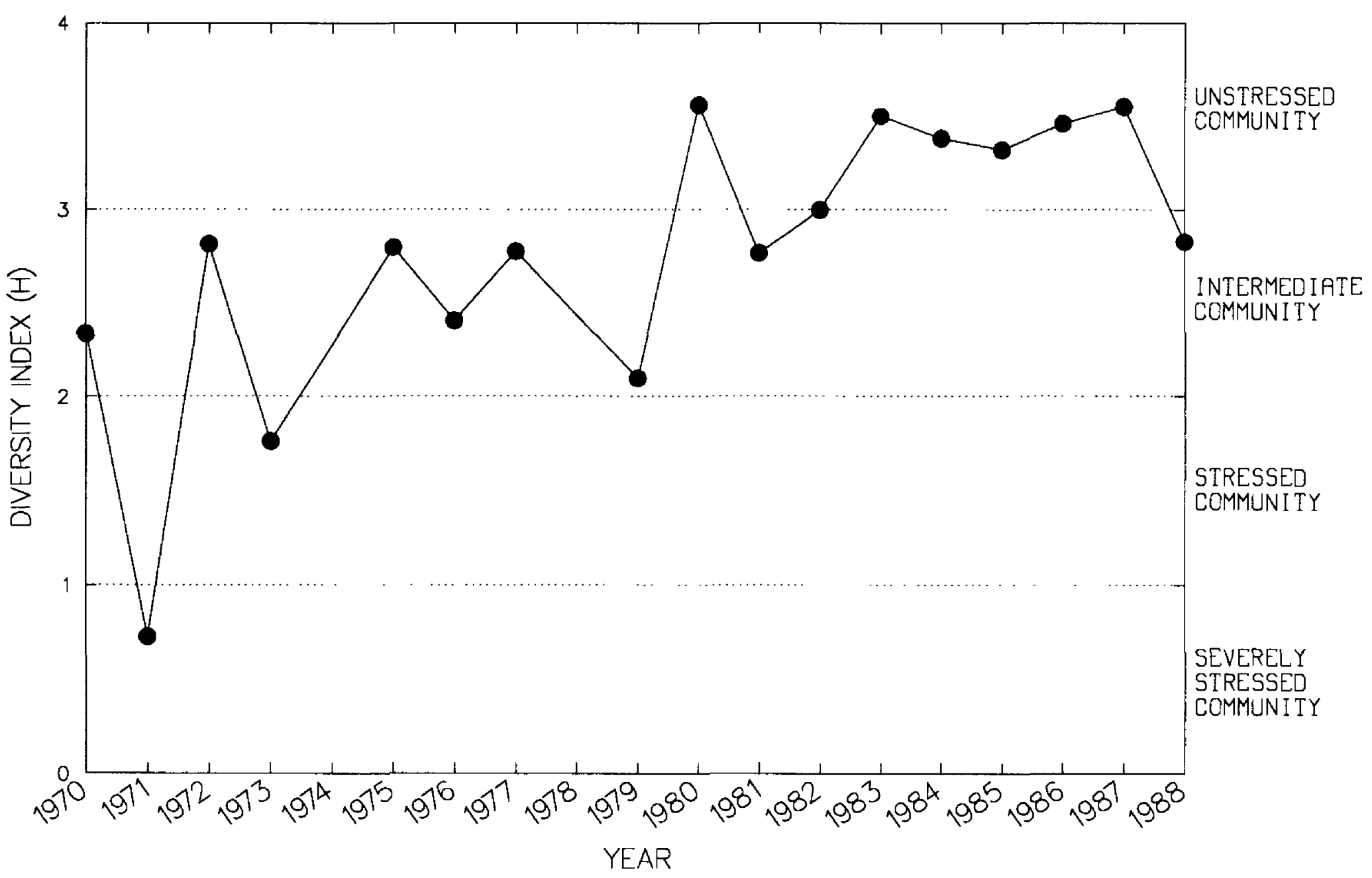


Site 6

\begin{tabular}{rcccccc}
\hline Year & $\begin{array}{c}\text { Total } \\
\text { number of } \\
\text { organisms }\end{array}$ & $\begin{array}{c}\text { Total } \\
\text { number } \\
\text { of taxa }\end{array}$ & $\begin{array}{c}\text { Brillouin's } \\
\text { diversity } \\
\text { index }(\mathrm{H})\end{array}$ & $\begin{array}{c}\text { Maximum } \\
\text { diversity } \\
\text { (Hmax) }\end{array}$ & $\begin{array}{c}\text { Minimum } \\
\text { diversity } \\
\text { (Hmin) }\end{array}$ & $\begin{array}{c}\text { Evenness } \\
\text { (E) }\end{array}$ \\
\hline 1970 & 124 & 2 & 0.79 & 0.97 & 0.06 & 0.81 \\
1971 & 30 & 2 & .79 & .91 & .16 & .85 \\
1972 & 508 & 12 & 1.58 & 3.54 & .19 & .41 \\
1973 & 391 & 6 & .85 & 2.55 & .11 & .31 \\
1974 & 177 & 8 & 1.72 & 2.89 & .29 & .55 \\
1975 & -- & -- & - & - & - &. \\
1976 & 285 & 23 & 2.97 & 4.40 & .63 & .62 \\
1977 & 34 & 8 & 1.74 & 2.68 & 1.02 & .43 \\
1979 & 132 & 11 & 2.20 & 3.24 & .53 & .62 \\
1980 & 272 & 15 & 2.05 & 3.77 & .41 & .49 \\
1981 & 2,754 & 32 & 3.08 & 4.95 & .13 & .61 \\
1982 & 1,261 & 27 & 3.53 & 4.76 & .21 & .73 \\
1983 & 2,081 & 37 & 3.33 & 5.16 & .19 & .63 \\
1984 & 998 & 26 & 3.49 & 4.66 & .25 & .74 \\
1985 & 546 & 26 & 2.22 & 4.54 & .41 & .44 \\
1986 & 650 & 38 & 3.60 & 5.08 & .53 & .67 \\
1987 & 1,471 & 34 & 3.57 & 5.03 & .24 & .70 \\
1988 & 820 & 24 & 3.29 & 4.50 & .27 & .71 \\
\hline
\end{tabular}

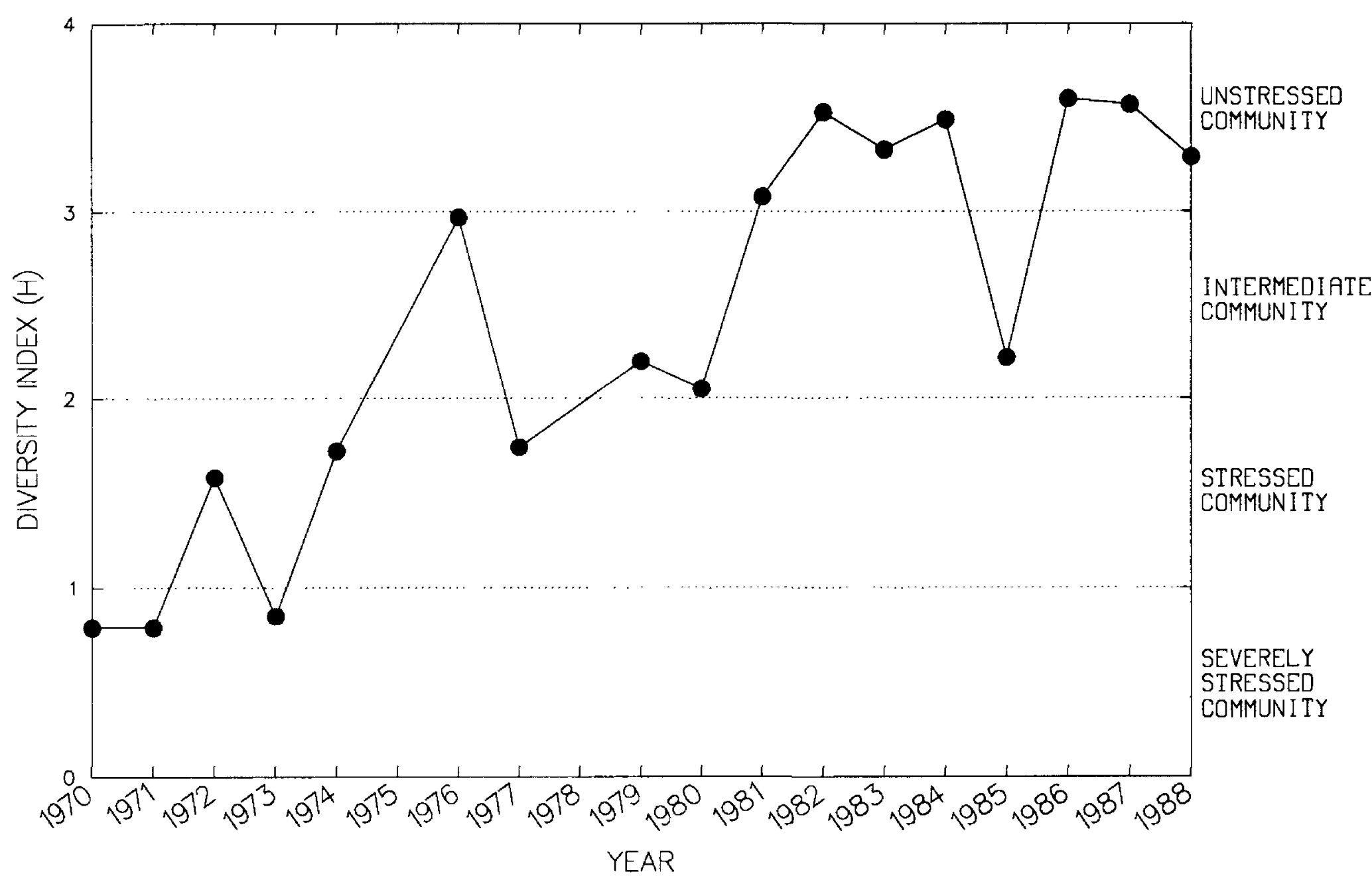


Site 7

\begin{tabular}{lcccccc}
\hline Year & $\begin{array}{c}\text { Total } \\
\text { number of } \\
\text { organisms }\end{array}$ & $\begin{array}{c}\text { Total } \\
\text { number } \\
\text { of taxa }\end{array}$ & $\begin{array}{c}\text { Brillouin's } \\
\text { diversity } \\
\text { index }(\mathrm{H})\end{array}$ & $\begin{array}{c}\text { Maximum } \\
\text { diversity } \\
\text { (Hmax) }\end{array}$ & $\begin{array}{c}\text { Minimum } \\
\text { diversity } \\
\text { (Hmin) }\end{array}$ & $\begin{array}{c}\text { Evenness } \\
\text { (E) }\end{array}$ \\
\hline 1970 & 93 & 6 & 1.50 & 2.55 & 0.35 & 0.52 \\
1971 & 47 & 3 & .80 & 1.63 & .24 & .41 \\
1972 & 109 & 11 & 2.44 & 3.50 & .62 & .63 \\
1973 & 13 & 2 & .48 & 1.04 & .28 & .26 \\
1974 & 146 & 19 & 3.59 & 4.18 & .88 & .82 \\
1975 & -- & -- & - & - & - & - \\
1976 & 495 & 21 & 3.17 & 4.36 & .36 & .70 \\
1977 & 200 & 24 & 3.17 & 4.39 & .87 & .65 \\
1979 & 124 & It & 2.05 & $3.3 \mathrm{i}$ & .56 & .54 \\
1980 & 850 & 29 & 3.54 & 4.79 & .32 & .72 \\
1981 & 1,512 & 32 & 3.52 & 4.95 & .22 & .70 \\
1982 & 1,785 & 27 & 2.97 & 4.70 & .16 & .62 \\
\hline
\end{tabular}

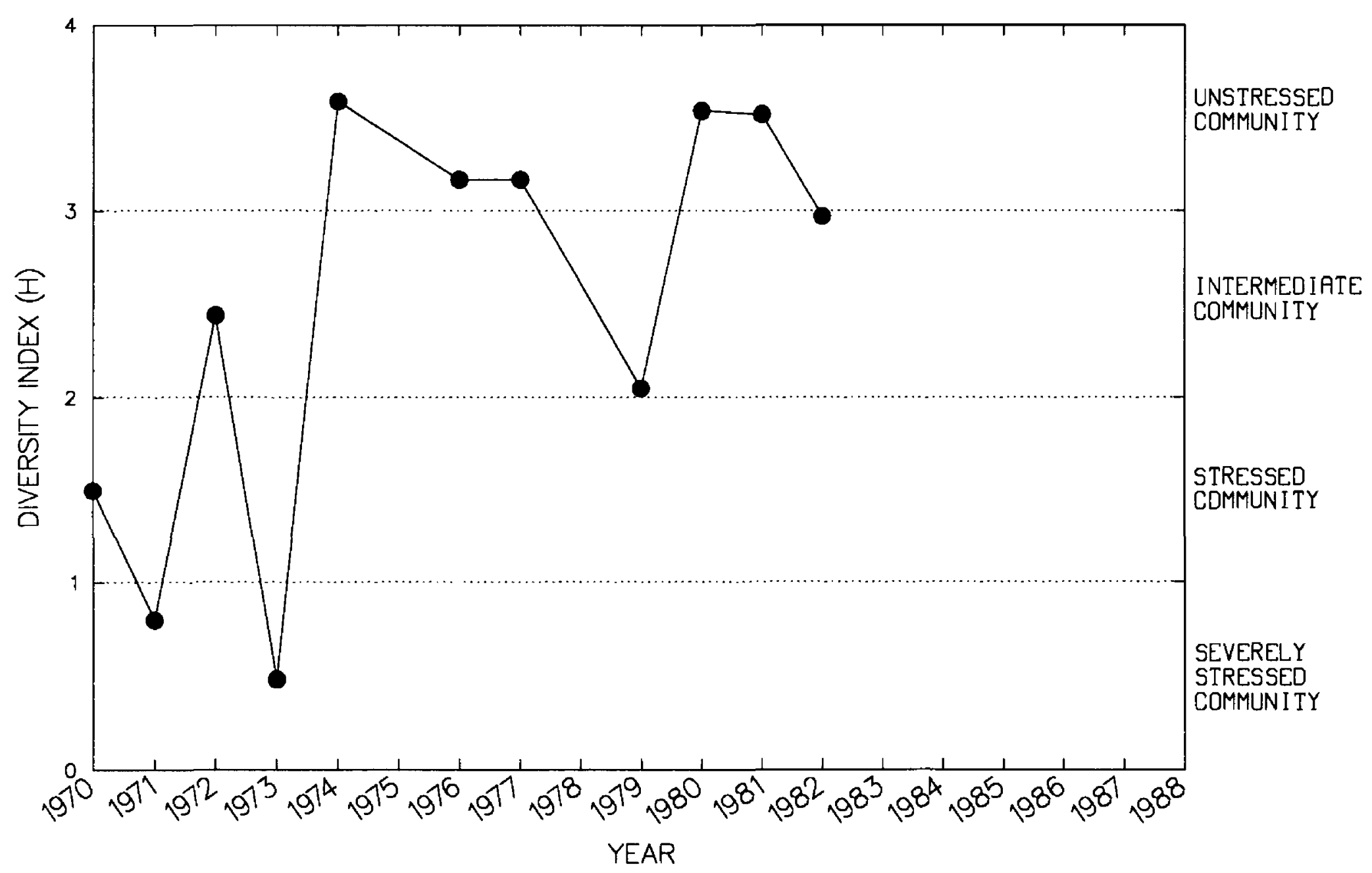


Site 8

\begin{tabular}{ccccccc}
\hline Year & $\begin{array}{c}\text { Total } \\
\text { number of } \\
\text { organisms }\end{array}$ & $\begin{array}{c}\text { Total } \\
\text { number } \\
\text { of taxa }\end{array}$ & $\begin{array}{c}\text { Brillouin's } \\
\text { diversity } \\
\text { index }(H)\end{array}$ & $\begin{array}{c}\text { Maximum } \\
\text { diversity } \\
(\text { Hmax) }\end{array}$ & $\begin{array}{c}\text { Minimum } \\
\text { diversity } \\
\text { (Hmin) }\end{array}$ & $\begin{array}{c}\text { Evenness } \\
\text { (E) }\end{array}$ \\
\hline 1970 & 94 & 6 & 2.23 & 2.59 & 0.35 & 0.84 \\
1971 & 26 & 4 & 1.65 & 1.94 & .54 & .79 \\
1972 & 288 & 15 & 2.39 & 3.79 & .40 & .59 \\
1973 & 486 & 20 & 2.32 & 4.24 & .35 & .51 \\
1974 & - & - & - & - & - & - \\
1975 & - & -- & - & - & - & - \\
1976 & 554 & 21 & 2.97 & 4.33 & .33 & .66 \\
1977 & 125 & 12 & 1.83 & 3.47 & 1.61 & .43 \\
1979 & 117 & 14 & 2.67 & 3.64 & .75 & .66 \\
1980 & 440 & 9 & 1.83 & 3.20 & .16 & .55 \\
1981 & 826 & 28 & 3.11 & 4.77 & .32 & .63 \\
1982 & 979 & 31 & 3.52 & 4.92 & .30 & .70 \\
\hline
\end{tabular}

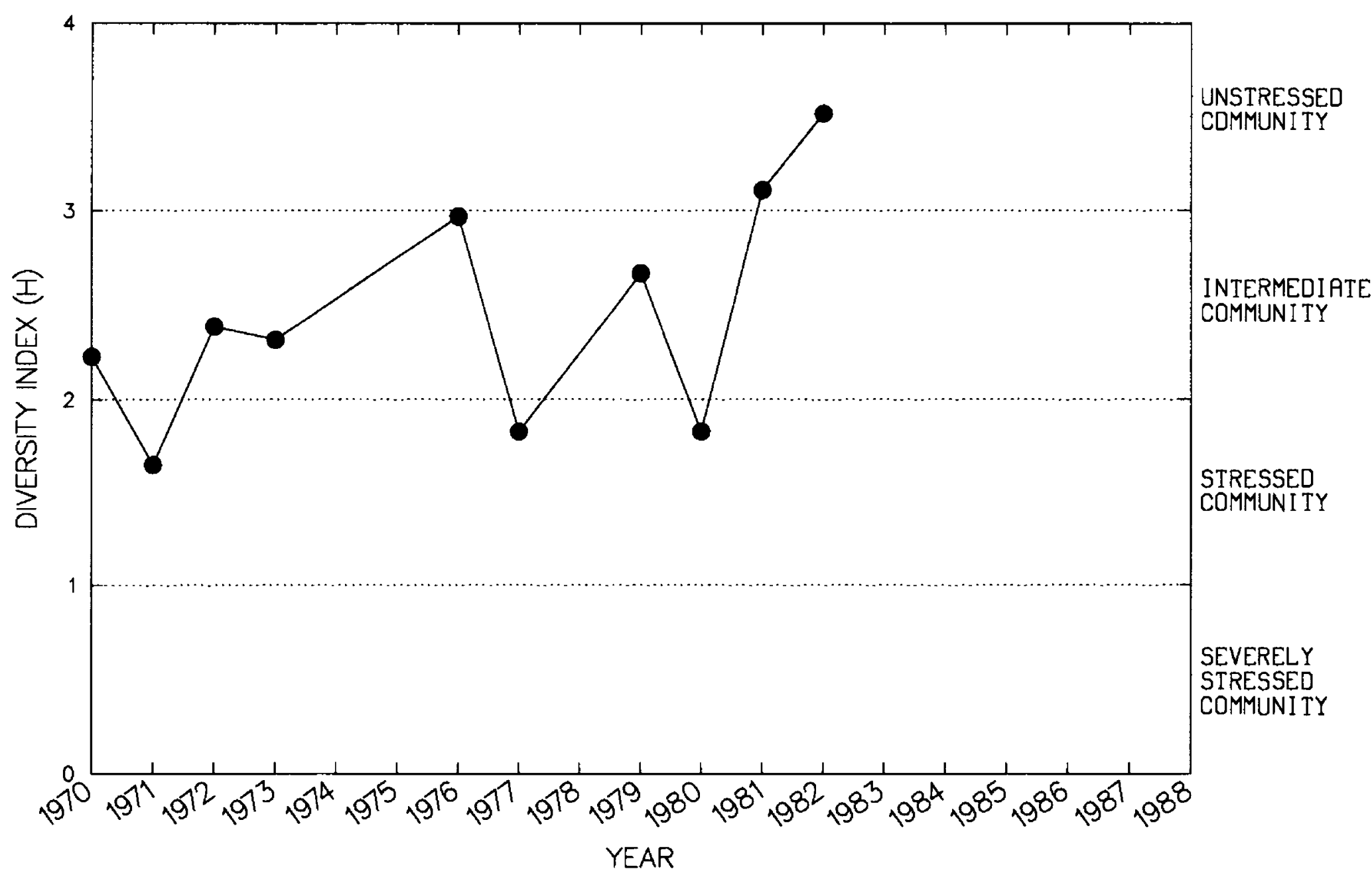


Site 9

\begin{tabular}{lcccccc}
\hline Year & $\begin{array}{c}\text { Total } \\
\text { number of } \\
\text { organisms }\end{array}$ & $\begin{array}{c}\text { Total } \\
\text { number } \\
\text { of taxa }\end{array}$ & $\begin{array}{c}\text { Brillouin's } \\
\text { diversity } \\
\text { index }(H)\end{array}$ & $\begin{array}{c}\text { Maximum } \\
\text { diversity } \\
\text { (Hmax) }\end{array}$ & $\begin{array}{c}\text { Minimum } \\
\text { diversity } \\
\text { (Hmin) }\end{array}$ & $\begin{array}{c}\text { Evenness } \\
\text { (E) }\end{array}$ \\
\hline 1970 & 132 & 7 & 2.41 & 2.85 & 0.32 & 0.83 \\
1971 & 37 & 4 & 1.51 & 1.88 & .42 & .75 \\
1972 & 125 & 9 & 2.16 & 3.22 & .44 & .62 \\
1973 & 361 & 15 & 1.99 & 3.78 & .33 & .48 \\
1974 & 131 & 11 & 1.65 & 3.51 & .53 & .38 \\
1975 & -- & -- & - & - & - & - \\
1976 & 579 & 21 & 2.51 & 4.37 & .32 & .54 \\
1977 & 42 & 7 & 2.11 & 2.46 & .76 & .79 \\
1979 & 290 & 21 & 2.63 & 4.40 & .56 & .54 \\
1980 & 254 & 11 & 2.75 & 3.34 & .31 & .80 \\
1981 & 482 & 23 & 3.03 & 4.57 & .41 & .63 \\
1982 & 914 & 24 & 3.30 & 4.50 & .25 & .72 \\
\hline
\end{tabular}

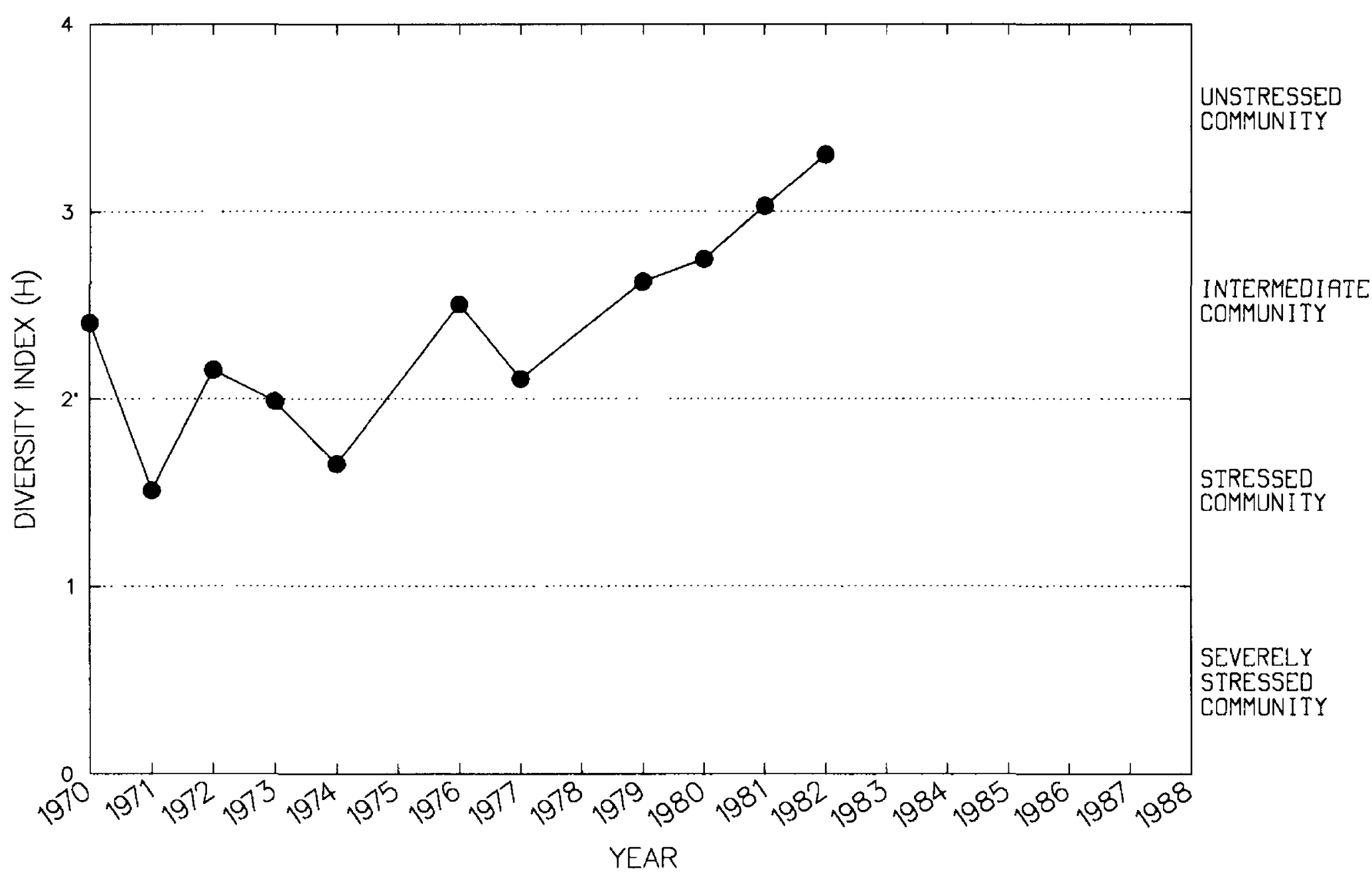


Site 10

\begin{tabular}{ccccccc}
\hline Year & $\begin{array}{c}\text { Total } \\
\text { number of } \\
\text { organisms }\end{array}$ & $\begin{array}{c}\text { Total } \\
\text { number } \\
\text { of taxa }\end{array}$ & $\begin{array}{c}\text { Brillouin's } \\
\text { diversity } \\
\text { index }(\mathrm{H})\end{array}$ & $\begin{array}{c}\text { Maximum } \\
\text { diversity } \\
\text { (Hmax) }\end{array}$ & $\begin{array}{c}\text { Minimum } \\
\text { diversity } \\
\text { (Hmin) }\end{array}$ & $\begin{array}{c}\text { Evenness } \\
\text { (E) }\end{array}$ \\
\hline 1970 & 104 & 8 & 2.45 & 2.80 & 0.45 & 0.85 \\
1971 & 24 & 4 & 1.50 & 1.71 & .57 & .81 \\
1972 & 548 & 15 & 1.88 & 3.89 & .23 & .45 \\
1973 & -- & -- & - & - & - & -- \\
1974 & -- & -- & - & -- & - & - \\
1975 & 767 & 19 & 2.90 & 4.21 & .22 & .67 \\
1976 & 880 & 26 & 2.62 & 4.72 & .28 & .53 \\
1977 & 344 & 27 & 2.87 & 4.74 & .63 & .55 \\
1979 & 32 & 10 & 2.15 & 2.87 & 1.35 & .53 \\
1980 & 620 & 19 & 3.19 & 4.24 & .27 & .74 \\
1981 & 2,787 & 33 & 3.07 & 5.03 & .13 & .60 \\
1982 & 1,686 & 30 & 3.39 & 4.86 & .18 & .69 \\
1983 & 972 & 24 & 3.20 & 4.56 & .23 & .69 \\
1984 & 1,492 & 29 & 3.50 & 4.83 & .20 & .71 \\
1985 & 1,031 & 21 & 2.82 & 4.33 & .19 & .63 \\
1986 & 1,121 & 24 & 3.35 & 4.59 & .21 & .72 \\
1987 & 2,097 & 39 & 3.86 & 5.29 & .20 & .72 \\
1988 & 2,400 & 31 & 3.57 & 4.93 & .14 & .71 \\
\hline
\end{tabular}

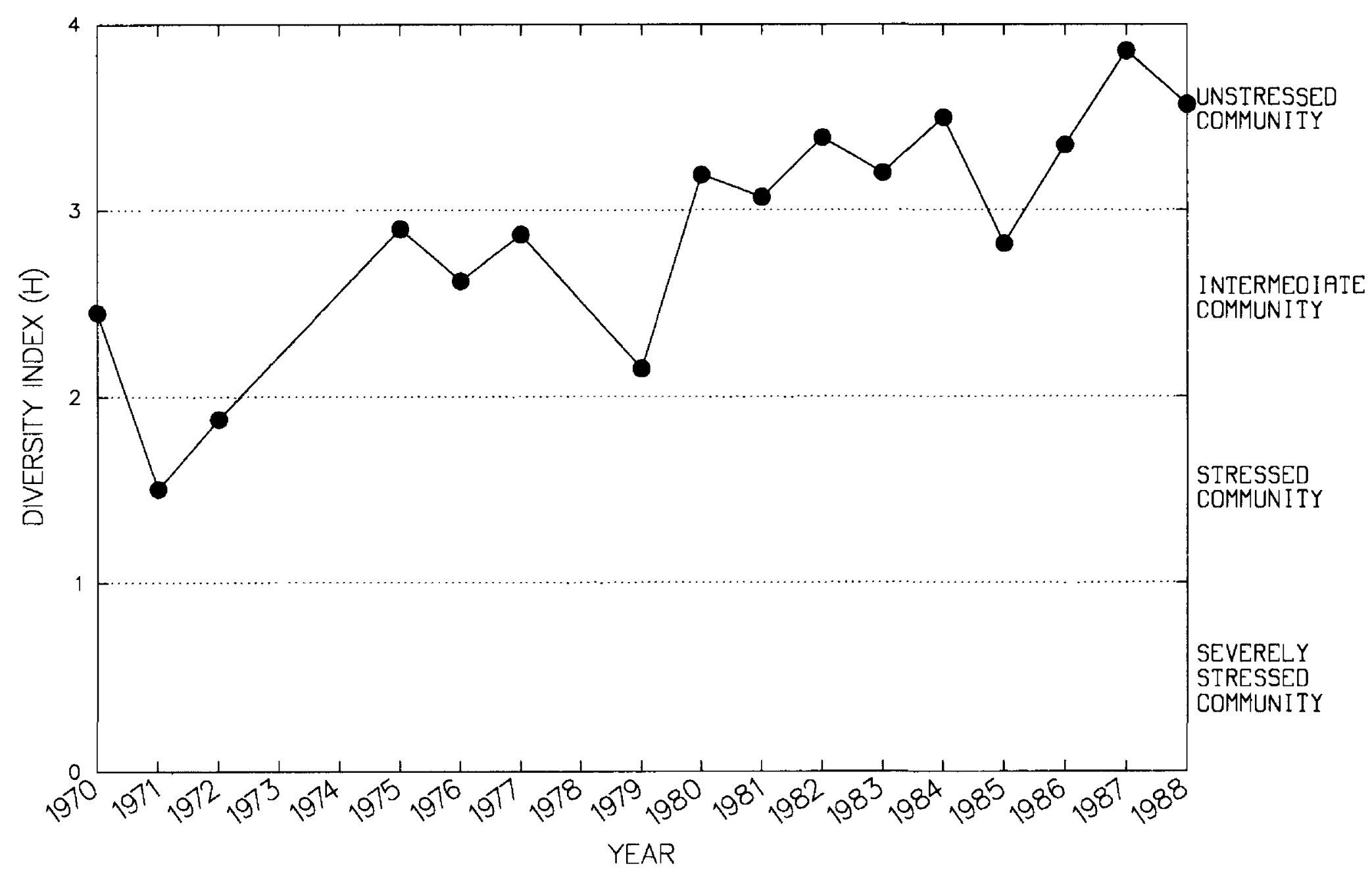


Slte 11

\begin{tabular}{ccccccc}
\hline Year & $\begin{array}{c}\text { Total } \\
\text { number of } \\
\text { organisms }\end{array}$ & $\begin{array}{c}\text { Total } \\
\text { number } \\
\text { of taxa }\end{array}$ & $\begin{array}{c}\text { Brillouin's } \\
\text { diversity } \\
\text { index }(\mathrm{H})\end{array}$ & $\begin{array}{c}\text { Maximum } \\
\text { diversity } \\
\text { (Hmax) }\end{array}$ & $\begin{array}{c}\text { Minimum } \\
\text { diversity } \\
(\text { Hmin) }\end{array}$ & $\begin{array}{c}\text { Evenness } \\
(\mathrm{E})\end{array}$ \\
\hline 1970 & -- & -- & - & -- & -- & - \\
1971 & -- & -- & - & -- & -- & - \\
1972 & 64 & 11 & 2.68 & 3.44 & 0.92 & 0.70 \\
1973 & 343 & 16 & 1.75 & 3.94 & .37 & .39 \\
1974 & 166 & 18 & 2.85 & 3.96 & .75 & .65 \\
1975 & - & - & - & - & - & - \\
1976 & 136 & 15 & 2.70 & 3.64 & .72 & .68 \\
1977 & 491 & 27 & 2.97 & 4.62 & .47 & .60 \\
1979 & 151 & 18 & 3.12 & 4.00 & .81 & .72 \\
1980 & 1,088 & 21 & 2.90 & 4.41 & .19 & .64 \\
1981 & 1,076 & 36 & 3.83 & 5.20 & .33 & .72 \\
1982 & 2,169 & 40 & 3.59 & 5.27 & .20 & .67 \\
\hline
\end{tabular}

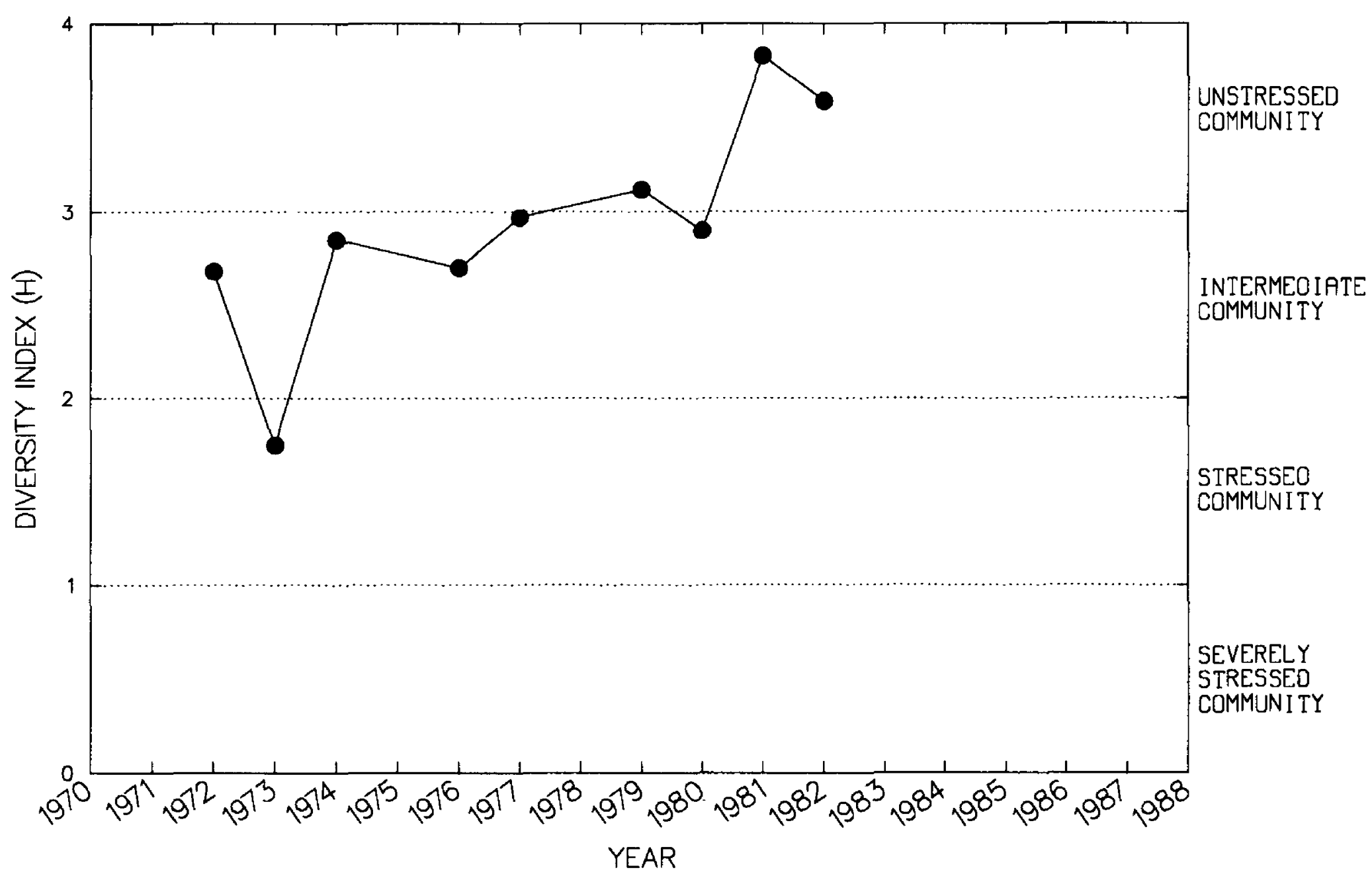


Site 12

\begin{tabular}{ccccccc}
\hline Year & $\begin{array}{c}\text { Total } \\
\text { number of } \\
\text { organisms }\end{array}$ & $\begin{array}{c}\text { Total } \\
\text { number } \\
\text { of taxa }\end{array}$ & $\begin{array}{c}\text { Brillouin's } \\
\text { diversity } \\
\text { index (H) }\end{array}$ & $\begin{array}{c}\text { Maximum } \\
\text { diversity } \\
\text { (Hmax) }\end{array}$ & $\begin{array}{c}\text { Minimum } \\
\text { diversity } \\
\text { (Hmin) }\end{array}$ & $\begin{array}{c}\text { Evenness } \\
\text { (E) }\end{array}$ \\
\hline 1970 & 118 & 7 & 2.32 & 2.86 & 0.35 & 0.79 \\
1971 & 36 & 7 & 2.17 & 2.49 & .84 & .81 \\
1972 & 1,053 & 19 & 2.69 & 4.22 & .17 & .62 \\
1973 & 288 & 20 & 2.00 & 4.22 & .54 & .40 \\
1974 & 271 & 20 & 3.06 & 4.26 & .56 & .68 \\
1975 & -- & - & - & - & - &. \\
1976 & 972 & 28 & 2.88 & 4.81 & .28 & .57 \\
1977 & 942 & 22 & 2.61 & 4.48 & .22 & .56 \\
1979 & 137 & 16 & 2.71 & 3.90 & .77 & .62 \\
1980 & 1,499 & 27 & 2.94 & 4.74 & .18 & .61 \\
1981 & 1,186 & 32 & 3.41 & 4.91 & .27 & .68 \\
1982 & 2,680 & 33 & 3.18 & 5.01 & .14 & .63 \\
1983 & 1,683 & 31 & 3.26 & 4.91 & .19 & .65 \\
1984 & 1,560 & 26 & 3.28 & 4.63 & .17 & .70 \\
1985 & 771 & 32 & 3.70 & 4.88 & .38 & .74 \\
1986 & 1,303 & 39 & 3.85 & 5.24 & .30 & .72 \\
1987 & 2,017 & 40 & 3.20 & 5.29 & .21 & .59 \\
1988 & 2,168 & 27 & 3.38 & 4.73 & .13 & .71 \\
\hline
\end{tabular}

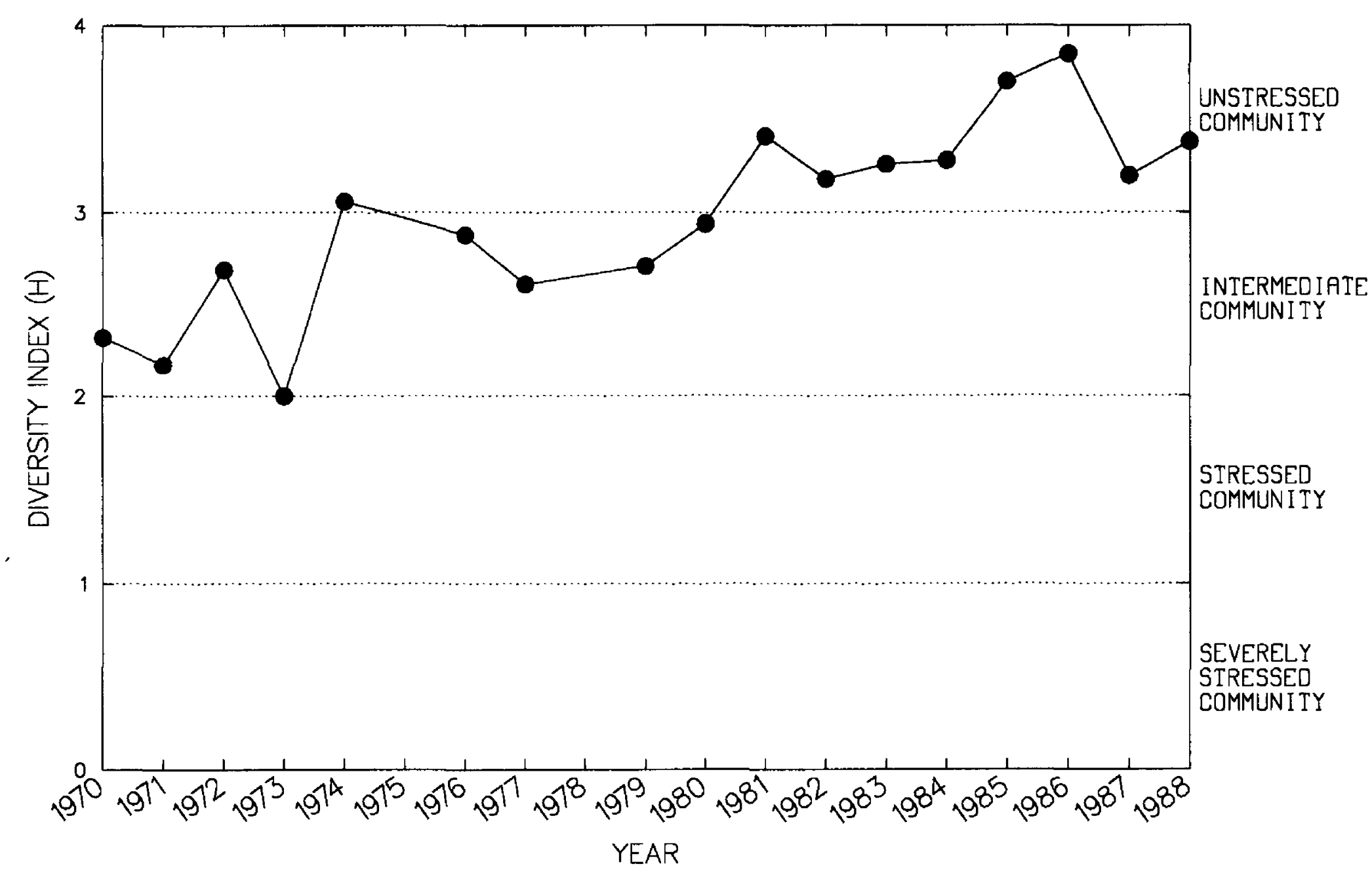


Site 13

\begin{tabular}{ccccccc}
\hline Year & $\begin{array}{c}\text { Total } \\
\text { number of } \\
\text { organisms }\end{array}$ & $\begin{array}{c}\text { Total } \\
\text { number } \\
\text { of taxa }\end{array}$ & $\begin{array}{c}\text { Brillouin's } \\
\text { diversity } \\
\text { index (H) }\end{array}$ & $\begin{array}{c}\text { Maximum } \\
\text { diversity } \\
\text { (Hmax) }\end{array}$ & $\begin{array}{c}\text { Minimum } \\
\text { diversity } \\
\text { (Hmin) }\end{array}$ & $\begin{array}{c}\text { Evenness } \\
\text { (E) }\end{array}$ \\
\hline 1970 & 58 & 8 & 2.30 & 2.79 & 0.70 & 0.77 \\
1971 & 23 & 5 & 1.80 & 2.24 & .77 & .70 \\
1972 & 272 & 23 & 2.89 & 4.53 & .65 & .58 \\
1973 & 101 & 14 & 2.21 & 3.56 & .85 & .50 \\
1974 & 31 & 8 & 2.30 & 2.97 & 1.08 & .64 \\
1975 & - & - & - & - & - & - \\
1976 & 160 & 18 & 3.12 & 4.19 & .77 & .69 \\
1977 & 380 & 22 & 3.27 & 4.34 & .47 & .72 \\
1979 & 163 & 29 & 3.80 & 4.71 & 1.24 & .74 \\
1980 & 694 & 21 & 3.31 & 4.29 & .27 & .76 \\
1981 & 1,541 & 43 & 3.88 & 5.44 & .29 & .70 \\
1982 & 2,429 & 35 & 3.21 & 5.10 & .16 & .62 \\
1983 & 1,607 & 38 & 3.82 & 5.119 & .24 & .72 \\
1984 & 1,291 & 27 & 3.51 & 4.77 & .21 & .72 \\
1985 & 539 & 36 & 3.18 & 5.21 & .59 & .56 \\
1986 & 1,396 & 31 & 3.01 & 4.87 & .22 & .60 \\
1987 & 1,338 & 31 & 2.50 & 4.89 & .23 & .49 \\
1988 & 1,846 & 31 & 3.12 & 4.94 & .18 & .62 \\
\hline
\end{tabular}

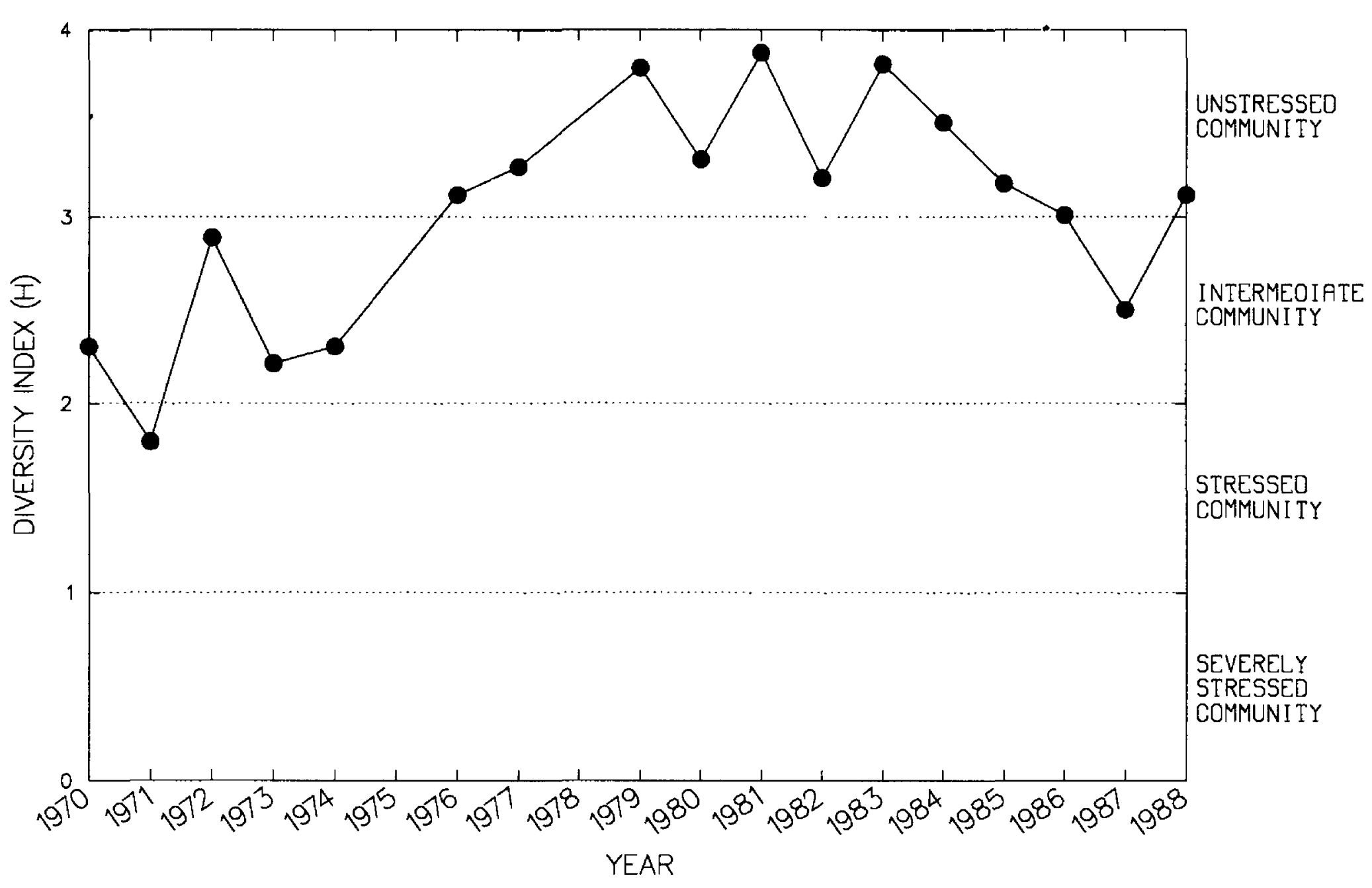


Site 14

\begin{tabular}{ccccccc}
\hline Year & $\begin{array}{c}\text { Total } \\
\text { number of } \\
\text { organisms }\end{array}$ & $\begin{array}{c}\text { Total } \\
\text { number } \\
\text { of taxa }\end{array}$ & $\begin{array}{c}\text { Brillouin's } \\
\text { diversity } \\
\text { index }(\mathrm{H})\end{array}$ & $\begin{array}{c}\text { Maximum } \\
\text { diversity } \\
\text { (Hmax) }\end{array}$ & $\begin{array}{c}\text { Minimum } \\
\text { diversity } \\
\text { (Hmin) }\end{array}$ & $\begin{array}{c}\text { Evenness } \\
\text { (E) }\end{array}$ \\
\hline 1970 & 58 & 8 & 2.23 & 2.79 & 0.70 & 0.73 \\
1971 & 34 & 6 & 1.88 & 2.54 & .74 & .63 \\
1972 & 643 & 27 & 3.00 & 4.77 & .38 & .60 \\
1973 & 225 & 15 & 1.73 & 3.71 & .48 & .39 \\
1974 & 189 & 16 & 2.79 & 4.01 & .60 & .64 \\
1975 & -- & -- & - & - & - & - \\
1976 & 362 & 27 & 2.91 & 4.65 & .61 & .57 \\
1977 & 747 & 27 & 3.04 & 4.74 & .33 & .61 \\
1979 & 96 & 16 & 2.44 & 3.61 & 1.01 & .55 \\
1980 & 615 & 26 & 3.37 & 4.68 & .38 & .70 \\
1981 & 1,763 & 35 & 3.42 & 5.09 & .21 & .66 \\
1982 & 1,543 & 29 & 2.88 & 4.81 & .19 & .58 \\
1983 & 1,427 & 40 & 3.63 & 5.31 & .29 & .66 \\
1984 & 1,719 & 31 & 3.20 & 4.93 & .19 & .64 \\
1985 & 421 & 24 & 3.33 & 4.53 & .47 & .70 \\
1986 & 1,419 & 32 & 3.32 & 4.96 & .23 & .65 \\
1987 & 1,328 & 31 & 2.03 & 4.97 & .23 & .38 \\
1988 & 2,589 & 33 & 3.72 & 5.03 & .14 & .73 \\
\hline
\end{tabular}

${ }^{1}$ Sampled upstream riffle because of bridge coristruction.

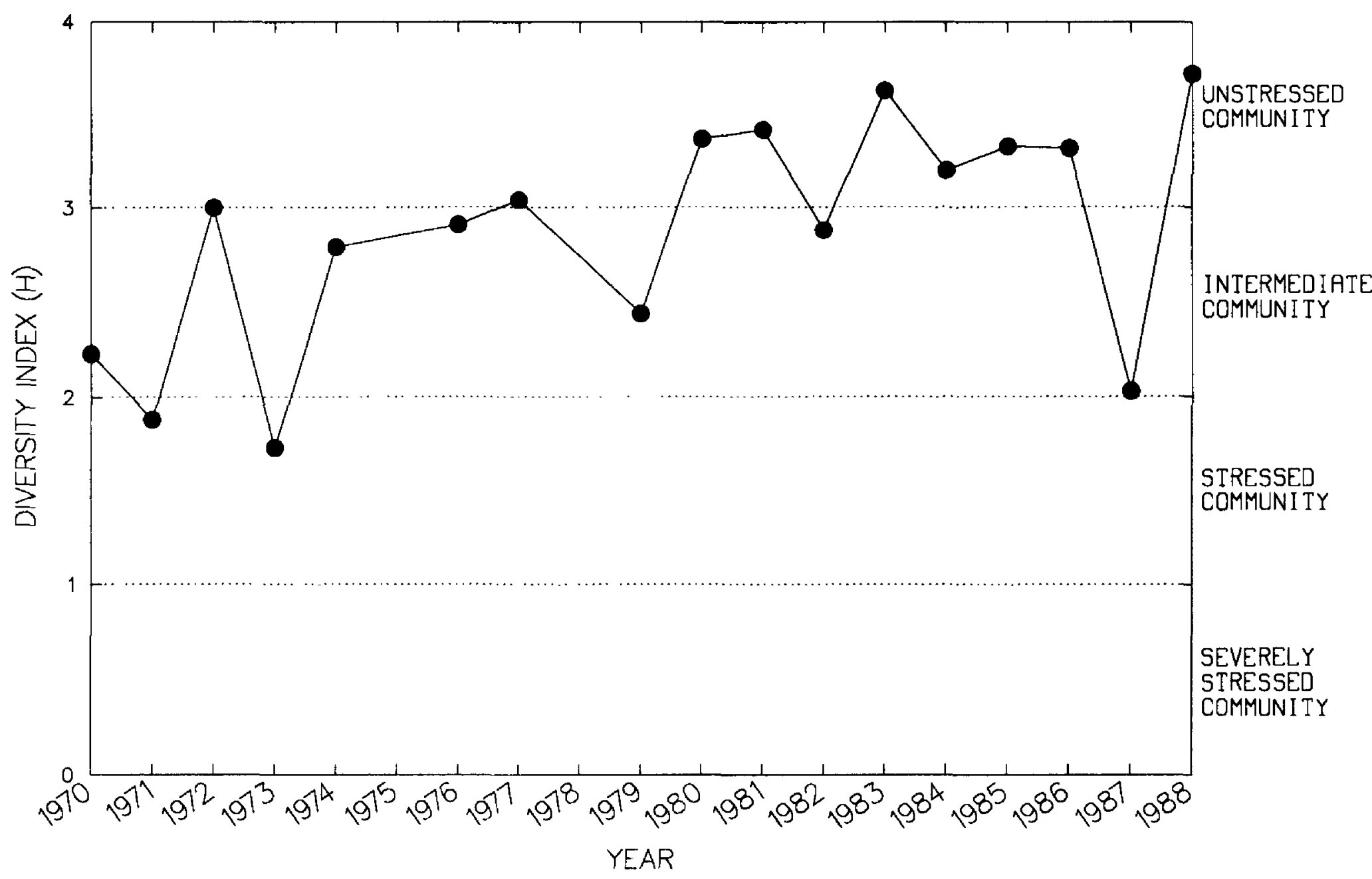


Site 15

\begin{tabular}{rcccccc}
\hline Year & $\begin{array}{c}\text { Total } \\
\text { number of } \\
\text { organisms }\end{array}$ & $\begin{array}{c}\text { Total } \\
\text { number } \\
\text { of taxa }\end{array}$ & $\begin{array}{c}\text { Brillouin's } \\
\text { diversity } \\
\text { index (H) }\end{array}$ & $\begin{array}{c}\text { Maximum } \\
\text { diversity } \\
\text { (Hmax) }\end{array}$ & $\begin{array}{c}\text { Minimum } \\
\text { diversity } \\
\text { (Hmin) }\end{array}$ & $\begin{array}{c}\text { Evenness } \\
\text { (E) }\end{array}$ \\
\hline 1970 & 56 & 7 & 2.20 & 2.53 & 0.62 & 0.83 \\
1971 & 24 & 6 & 1.64 & 2.15 & .93 & .58 \\
1972 & 324 & 19 & 3.05 & 4.08 & .46 & .72 \\
1973 & 96 & 11 & 1.86 & 3.44 & .68 & .43 \\
1974 & 85 & 14 & 2.58 & 3.46 & .96 & .65 \\
1975 & 232 & 21 & 3.02 & 4.15 & .67 & .67 \\
1976 & 277 & 22 & 2.70 & 4.40 & .61 & .55 \\
1977 & 645 & 31 & 3.34 & 4.96 & .43 & .64 \\
1979 & 174 & 10 & 1.86 & 3.25 & .38 & .51 \\
1980 & 629 & 27 & 3.60 & 4.67 & .38 & .75 \\
1981 & 3,444 & 32 & 2.34 & 5.00 & .11 & .46 \\
1982 & 546 & 22 & 3.06 & 4.48 & .35 & .66 \\
1983 & 1,138 & 28 & 2.82 & 4.80 & .24 & .57 \\
1984 & 820 & 29 & 3.32 & 4.78 & .33 & .67 \\
1985 & 226 & 30 & 3.92 & 4.77 & .99 & .77 \\
1986 & 719 & 36 & 3.77 & 5.21 & .46 & .70 \\
1987 & 602 & 35 & 2.76 & 4.99 & .52 & .50 \\
1988 & 2,493 & 41 & 3.19 & 5.37 & .18 & .58 \\
\hline
\end{tabular}

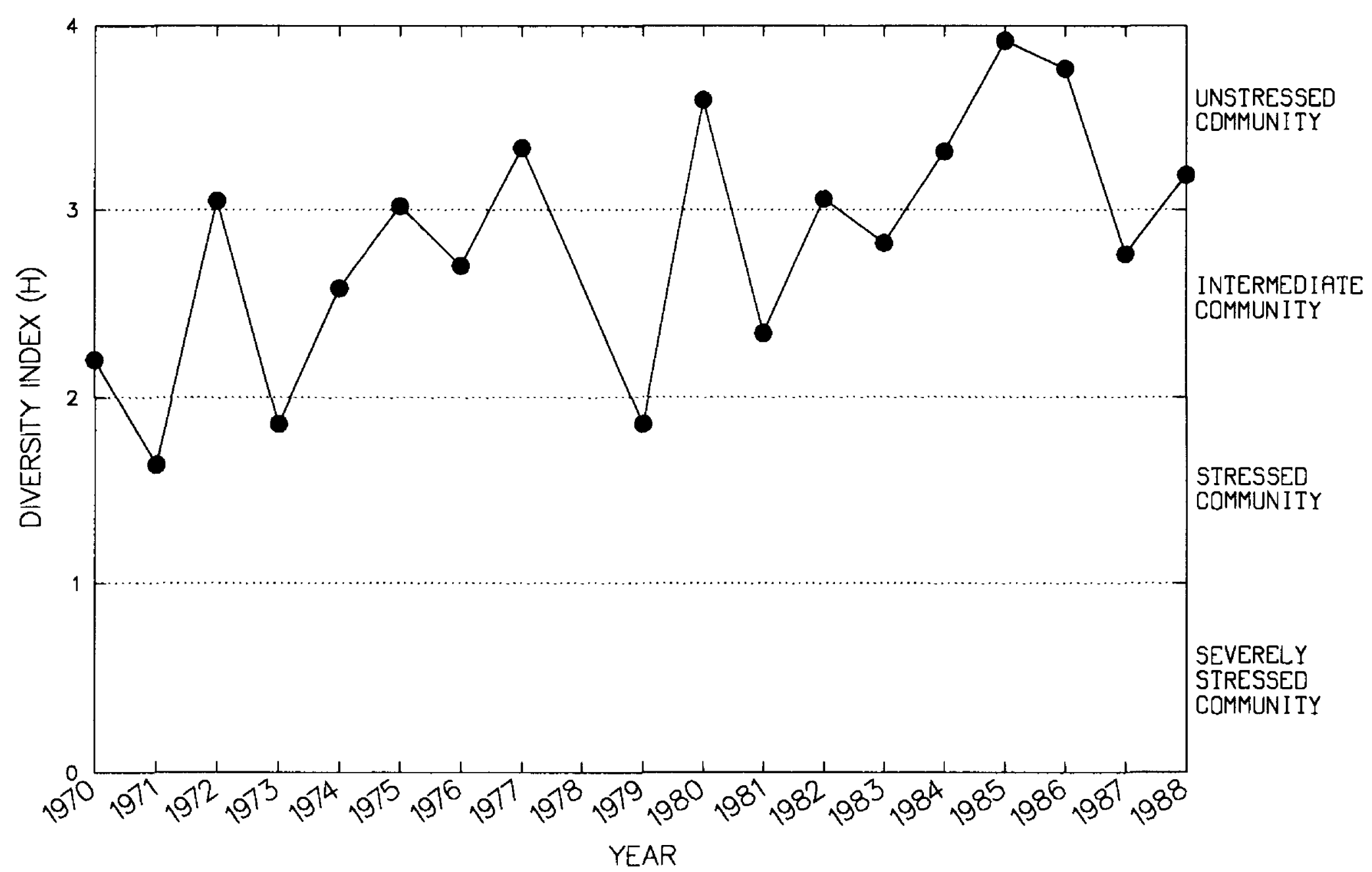


Site 16

\begin{tabular}{ccccccc}
\hline Year & $\begin{array}{c}\text { Total } \\
\text { number of } \\
\text { organisms }\end{array}$ & $\begin{array}{c}\text { Total } \\
\text { number } \\
\text { of taxa }\end{array}$ & $\begin{array}{c}\text { Brillouin's } \\
\text { diversity } \\
\text { index (H) }\end{array}$ & $\begin{array}{c}\text { Maximum } \\
\text { diversity } \\
\text { (Hmax) }\end{array}$ & $\begin{array}{c}\text { Minimum } \\
\text { diversity } \\
\text { (Hmin) }\end{array}$ & $\begin{array}{c}\text { Evenness } \\
\text { (E) }\end{array}$ \\
\hline 1981 & 243 & 8 & 0.53 & 2.96 & 0.23 & 0.11 \\
1982 & 620 & 20 & 1.43 & 4.21 & .28 & .29 \\
1983 & 342 & 24 & 2.82 & 4.44 & .56 & .58 \\
1984 & 2,246 & 18 & 1.13 & 4.18 & .08 & .26 \\
1985 & 72 & 21 & 3.11 & 4.03 & 1.66 & .61 \\
1986 & 599 & 21 & 2.25 & 4.36 & .31 & .48 \\
1987 & 490 & 25 & 2.75 & 4.61 & .44 & .55 \\
1988 & 1,337 & 20 & 2.04 & 4.34 & .15 & .45 \\
\hline
\end{tabular}

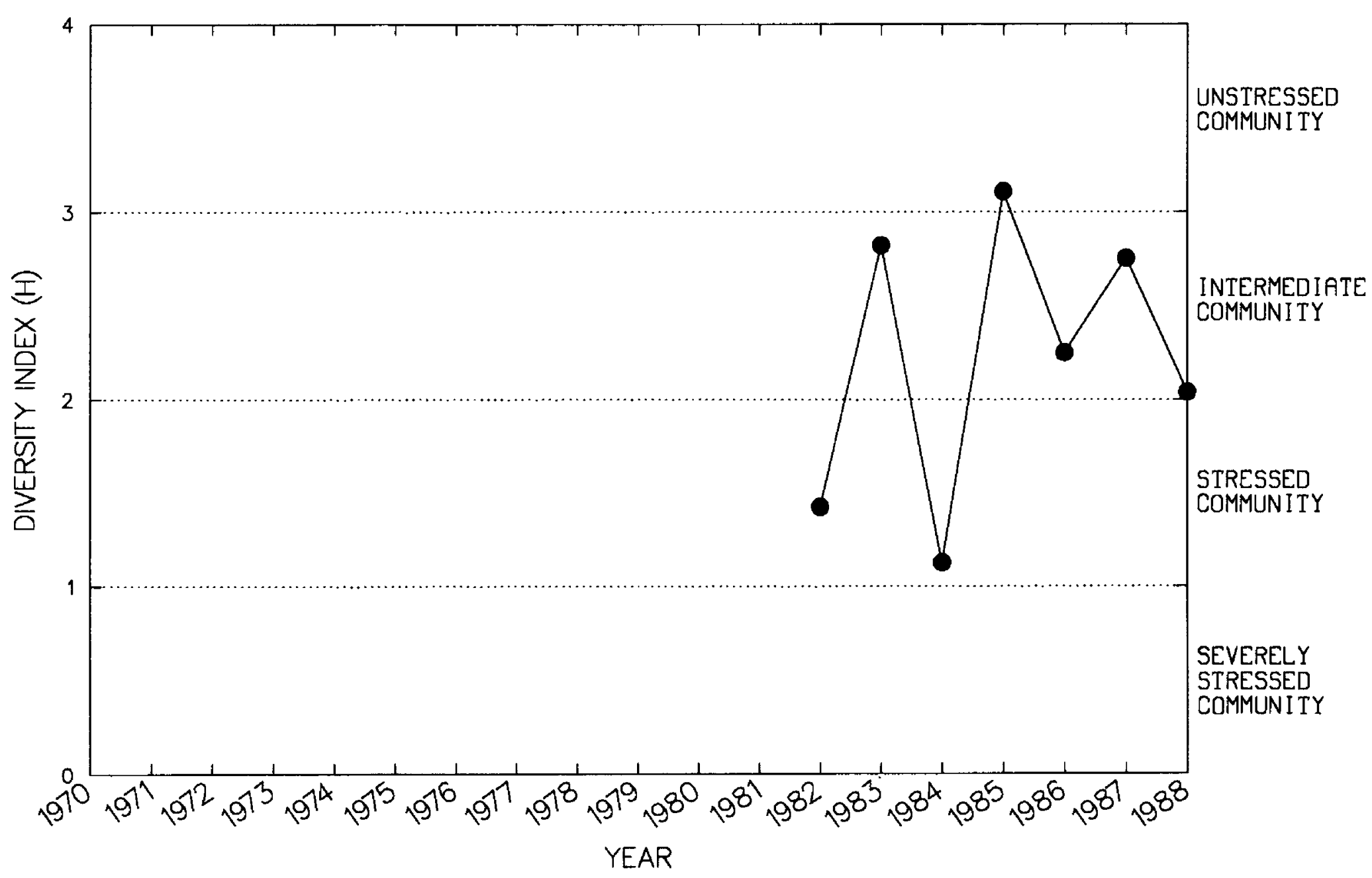


Site 17

\begin{tabular}{ccccccc}
\hline Year & $\begin{array}{c}\text { Total } \\
\text { number of } \\
\text { organisms }\end{array}$ & $\begin{array}{c}\text { Total } \\
\text { number } \\
\text { of taxa }\end{array}$ & $\begin{array}{c}\text { Brillouin's } \\
\text { diversity } \\
\text { index (H) }\end{array}$ & $\begin{array}{c}\text { Maximum } \\
\text { diversity } \\
\text { (Hmax) }\end{array}$ & $\begin{array}{c}\text { Minimum } \\
\text { diversity } \\
\text { (Hmin) }\end{array}$ & $\begin{array}{c}\text { Evenness } \\
\text { (E) }\end{array}$ \\
\hline 1970 & 46 & 3 & 1.20 & 1.54 & 0.24 & 0.74 \\
1971 & 8 & 3 & 1.02 & 1.54 & .73 & .36 \\
1972 & 155 & 10 & 1.98 & 3.27 & .42 & .55 \\
1973 & -- & - & - & - & -- & - \\
1974 & 239 & 11 & 2.11 & 3.47 & .33 & .57 \\
1975 & 690 & 15 & 2.36 & 3.83 & .19 & .60 \\
1976 & 473 & 21 & 2.99 & 4.35 & .37 & .66 \\
1977 & 555 & 18 & 2.75 & 4.19 & .28 & .63 \\
1979 & 362 & 18 & 2.87 & 4.04 & .40 & .68 \\
1980 & 468 & 15 & 2.90 & 3.83 & .26 & .74 \\
1981 & 528 & 23 & 3.35 & 4.57 & .38 & .71 \\
1982 & 215 & 20 & 3.44 & 4.30 & .68 & .76 \\
1983 & 404 & 28 & 3.26 & 4.71 & .58 & .65 \\
1984 & 1,188 & 28 & 3.58 & 4.77 & .23 & .74 \\
1985 & 965 & 26 & 3.42 & 4.62 & .26 & .73 \\
1986 & 709 & 26 & 3.57 & 4.62 & .33 & .76 \\
1987 & 1,114 & 27 & 3.70 & 4.70 & .24 & .78 \\
1988 & 2,032 & 24 & 2.60 & 4.59 & .12 & .56 \\
\hline
\end{tabular}

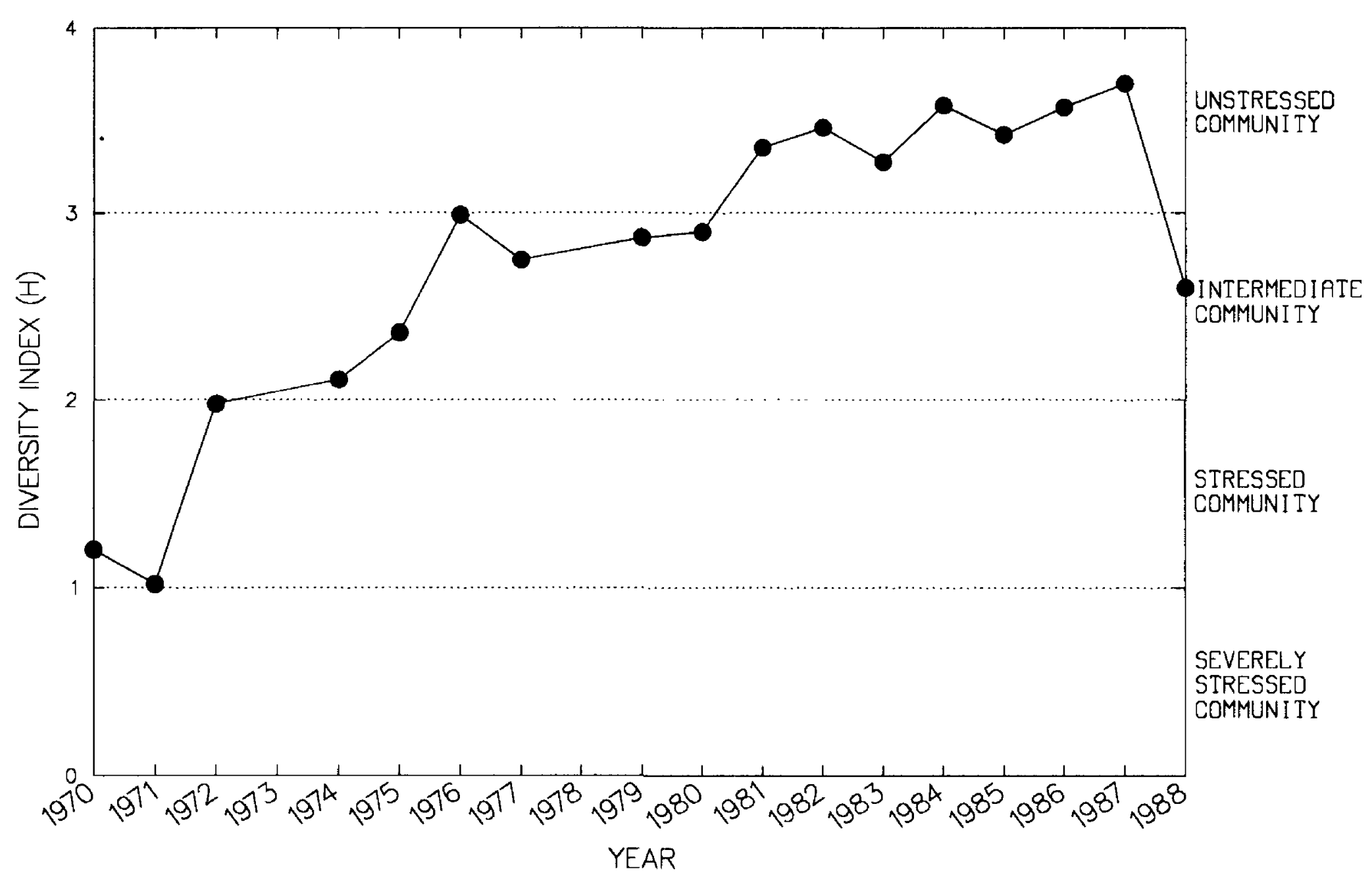


Site 18

\begin{tabular}{ccccccc}
\hline Year & $\begin{array}{c}\text { Total } \\
\text { number of } \\
\text { organisms }\end{array}$ & $\begin{array}{c}\text { Total } \\
\text { number } \\
\text { of taxa }\end{array}$ & $\begin{array}{c}\text { Brillouin's } \\
\text { diversity } \\
\text { index (H) }\end{array}$ & $\begin{array}{c}\text { Maximum } \\
\text { diversity } \\
\text { (Hmax) }\end{array}$ & $\begin{array}{c}\text { Minimum } \\
\text { diversity } \\
\text { (Hmin) }\end{array}$ & $\begin{array}{c}\text { Evenness } \\
\text { (E) }\end{array}$ \\
\hline 1970 & 125 & 8 & 2.08 & 2.99 & 0.39 & 0.65 \\
1971 & 28 & 4 & 1.59 & 1.74 & .51 & .87 \\
1972 & 129 & 11 & 2.18 & 3.45 & .54 & .56 \\
1973 & 132 & 12 & 1.97 & 3.34 & .58 & .50 \\
1974 & - & -- & - & - & - & - \\
1975 & - & -- & - & - & -- & .78 \\
1976 & 212 & 23 & 3.55 & 4.31 & .79 & .59 \\
1977 & 221 & 25 & 3.08 & 4.64 & .84 & .49 \\
1979 & 22 & 9 & 2.14 & 2.77 & 1.53 & .59 \\
1980 & 46 & 13 & 2.61 & 3.44 & 1.39 & \\
1981 & 1,134 & 29 & 3.53 & 4.78 & .25 & .73 \\
1982 & 578 & 27 & 3.62 & 4.68 & .41 & .75 \\
\hline
\end{tabular}

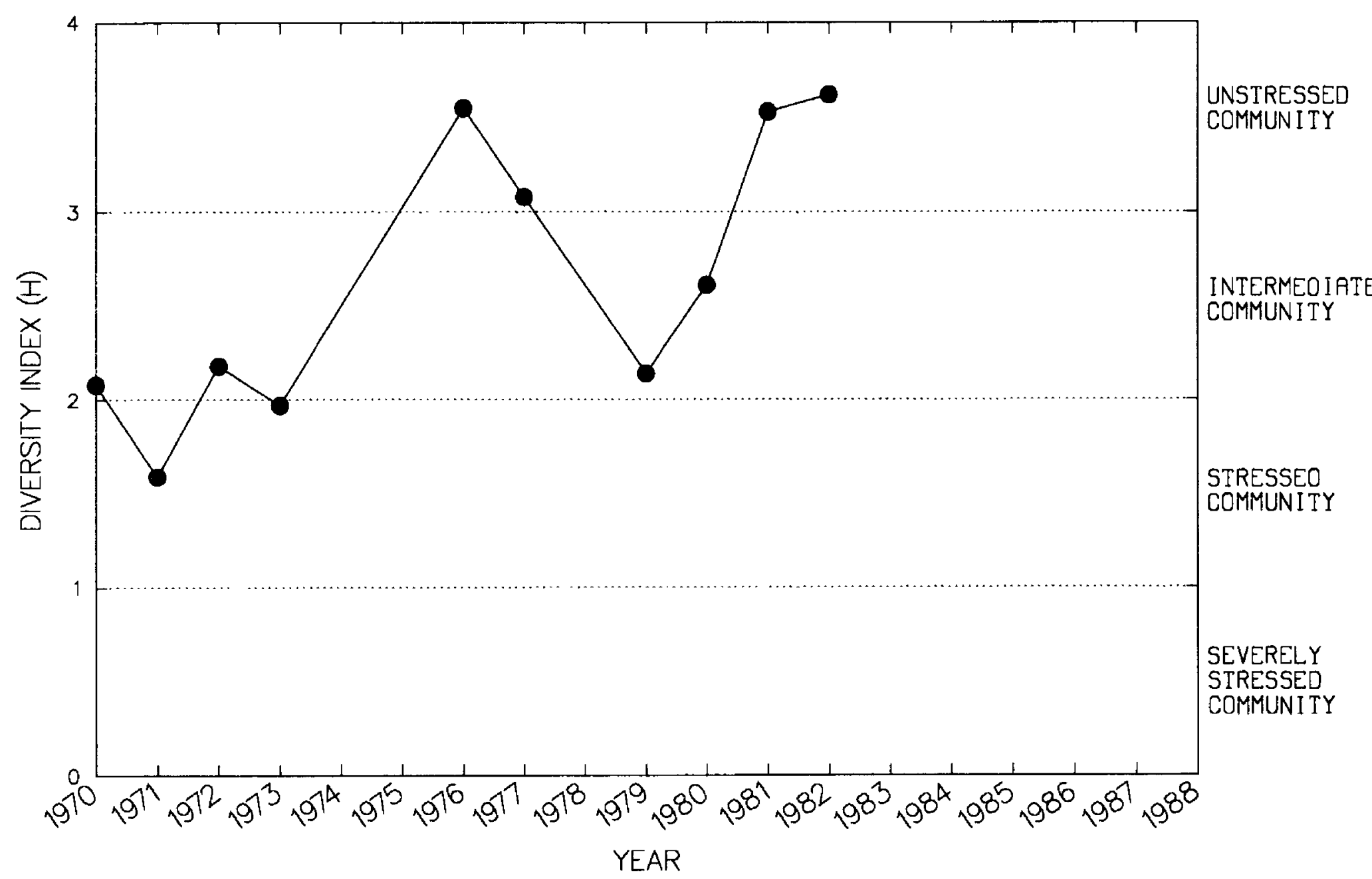




\section{Site 19}

\begin{tabular}{ccccccc}
\hline Year & $\begin{array}{c}\text { Total } \\
\text { number of } \\
\text { organisms }\end{array}$ & $\begin{array}{c}\text { Total } \\
\text { number } \\
\text { of taxa }\end{array}$ & $\begin{array}{c}\text { Brillouin's } \\
\text { diversity } \\
\text { index }(\mathrm{H})\end{array}$ & $\begin{array}{c}\text { Maximum } \\
\text { diversity } \\
\text { (Hmax) }\end{array}$ & $\begin{array}{c}\text { Minimum } \\
\text { diversity } \\
\text { (Hmin) }\end{array}$ & $\begin{array}{c}\text { Evenness } \\
\text { (E) }\end{array}$ \\
\hline 1970 & 88 & 9 & 1.87 & 3.18 & 0.58 & 0.50 \\
1971 & 45 & 6 & 1.90 & 2.50 & .60 & .68 \\
1972 & 219 & 8 & 1.64 & 2.95 & .25 & .51 \\
1973 & 120 & 17 & 2.66 & 3.76 & .91 & .61 \\
1974 & 67 & 14 & 2.55 & 3.73 & 1.15 & .54 \\
1975 & - & - & - & - & - & - \\
1976 & 363 & 25 & 3.16 & 4.57 & .56 & .65 \\
1977 & 835 & 27 & 2.85 & 4.79 & .30 & .57 \\
1979 & 131 & 12 & 2.72 & 3.63 & .59 & .70 \\
1980 & 417 & 16 & 3.16 & 3.88 & .31 & .80 \\
1981 & 994 & 38 & 3.61 & 5.14 & .37 & .68 \\
1982 & 1,628 & 35 & 3.38 & 5.11 & .22 & .65 \\
1983 & 526 & 30 & 3.12 & 4.85 & .50 & .60 \\
1984 & 1,220 & 26 & 3.07 & 4.73 & .21 & .63 \\
1985 & 571 & 28 & 2.85 & 4.73 & .43 & .56 \\
1986 & 912 & 28 & 2.85 & 4.78 & .29 & .57 \\
1987 & 1,286 & 33 & 3.91 & 5.08 & .26 & .76 \\
1988 & 1,987 & 24 & 2.01 & 4.59 & .13 & .42 \\
\hline
\end{tabular}

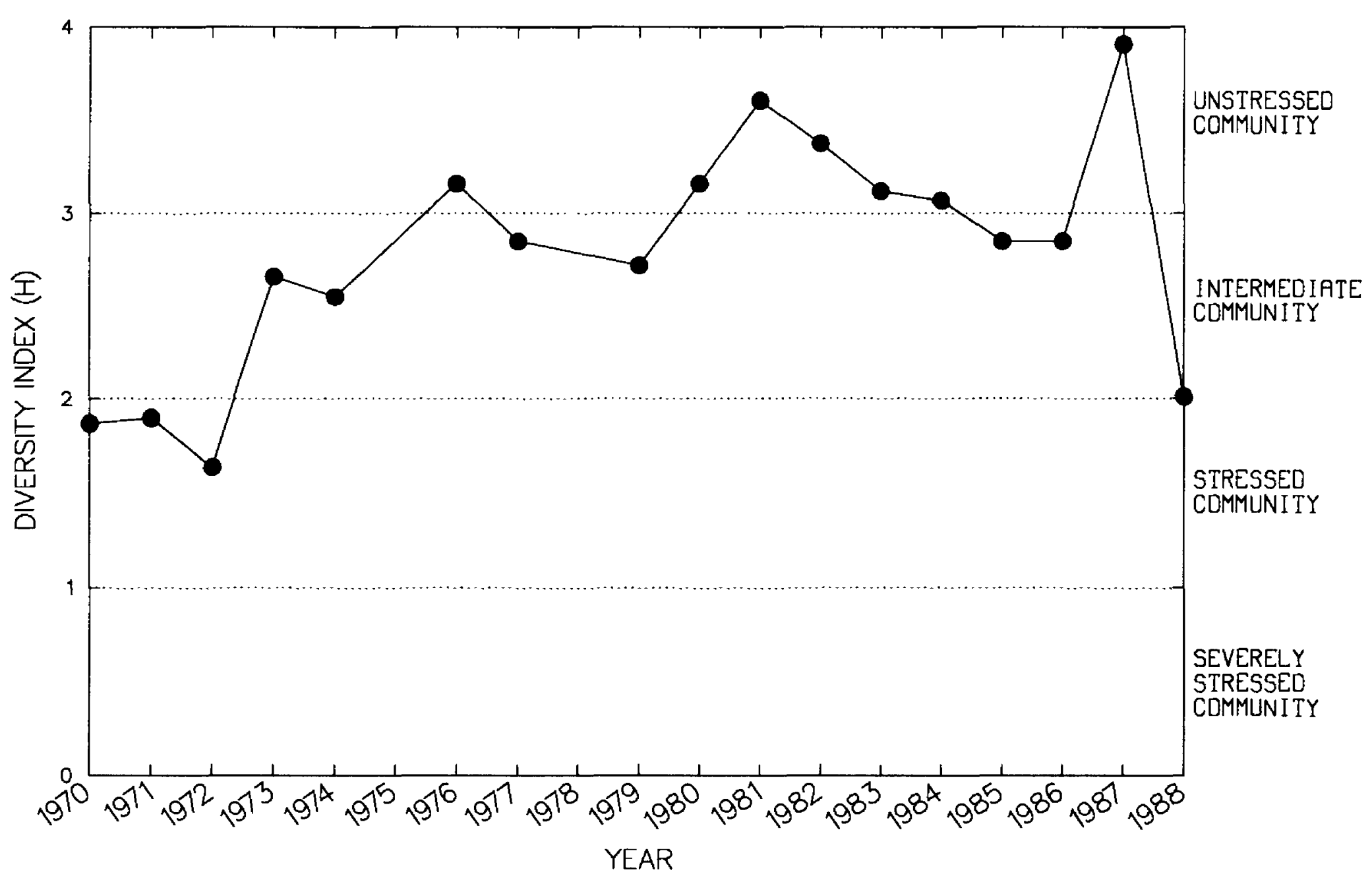


Site 20

\begin{tabular}{rcccccc}
\hline Year & $\begin{array}{c}\text { Total } \\
\text { number of } \\
\text { organisms }\end{array}$ & $\begin{array}{c}\text { Total } \\
\text { number } \\
\text { of taxa }\end{array}$ & $\begin{array}{c}\text { Brillouin's } \\
\text { diversity } \\
\text { index (H) }\end{array}$ & $\begin{array}{c}\text { Maximum } \\
\text { diversity } \\
\text { (Hmax) }\end{array}$ & $\begin{array}{c}\text { Minimum } \\
\text { diversity } \\
\text { (Hmin) }\end{array}$ & $\begin{array}{c}\text { Evenness } \\
\text { (E) }\end{array}$ \\
\hline 1970 & 116 & 5 & 1.20 & 2.25 & 0.24 & 0.48 \\
1971 & 15 & 2 & .84 & 1.04 & .26 & .74 \\
1972 & 158 & 14 & 2.56 & 3.66 & .60 & .64 \\
1973 & 246 & 13 & 1.59 & 3.75 & .39 & .36 \\
1974 & -- & -- & - & - & - & - \\
1975 & 788 & 20 & 2.64 & 4.28 & .23 & .59 \\
1976 & 420 & 17 & 2.92 & 4.09 & .33 & .69 \\
1977 & 349 & 15 & 2.52 & 3.82 & .34 & .63 \\
1979 & 84 & 14 & 2.71 & 3.42 & .97 & .71 \\
1980 & 202 & 18 & 2.39 & 3.99 & .64 & .52 \\
1981 & 241 & 27 & 3.14 & 4.78 & .85 & .58 \\
1982 & 1,342 & 29 & 3.60 & 4.81 & .22 & .74 \\
1983 & 850 & 22 & 3.31 & 4.45 & .24 & .73 \\
1984 & 1,700 & 21 & 3.02 & 4.42 & .13 & .67 \\
1985 & 719 & 19 & 2.89 & 4.27 & .24 & .66 \\
1986 & 977 & 26 & 3.61 & 4.68 & .25 & .76 \\
1987 & 1,878 & 30 & 3.73 & 4.90 & .17 & .75 \\
1988 & 1,643 & 26 & 3.39 & 4.65 & .16 & .72 \\
\hline & & & & & & \\
\hline
\end{tabular}

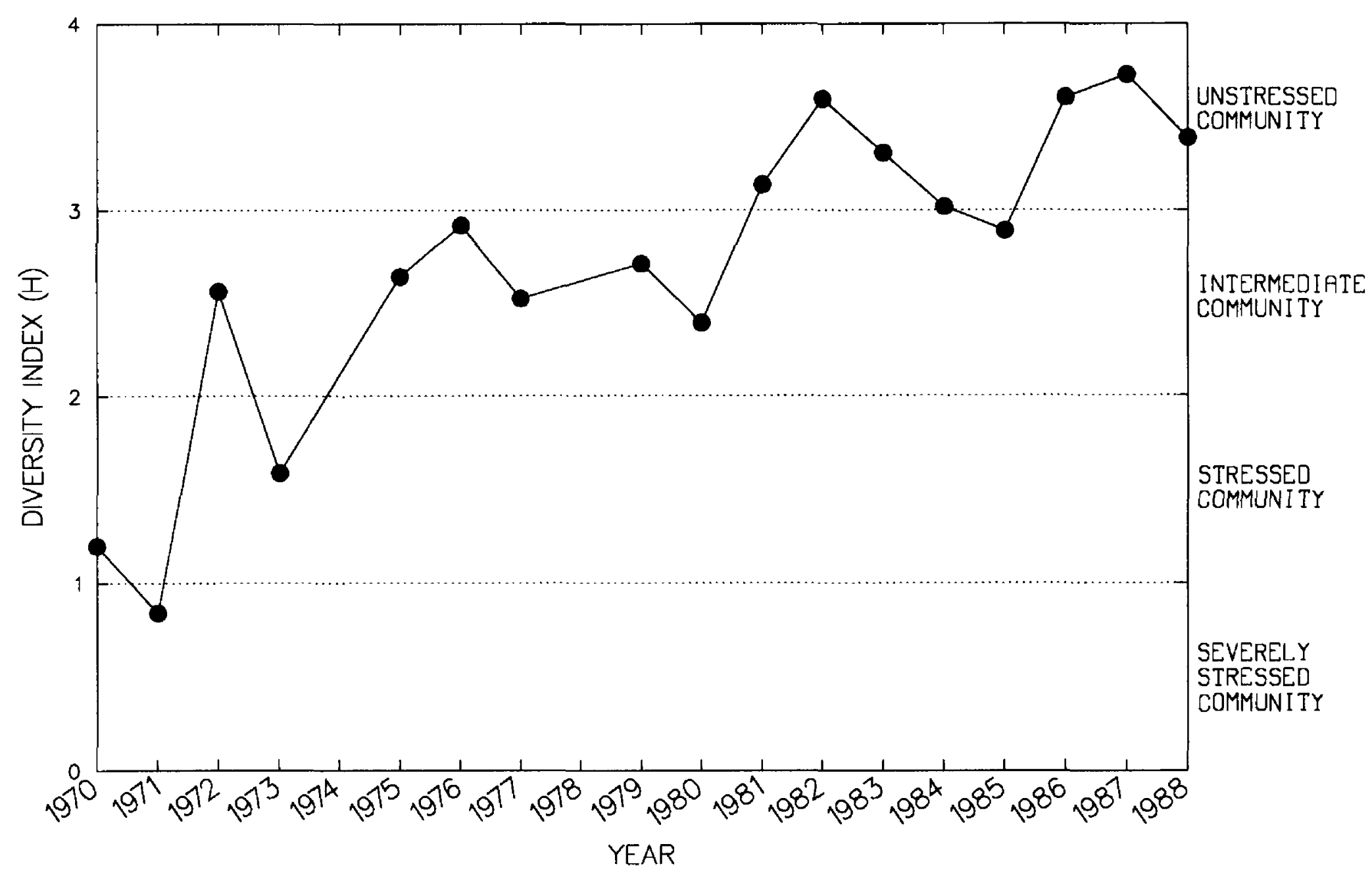


Site 21

\begin{tabular}{ccccccc}
\hline Year & $\begin{array}{c}\text { Total } \\
\text { number of } \\
\text { organisms }\end{array}$ & $\begin{array}{c}\text { Total } \\
\text { number } \\
\text { of taxa }\end{array}$ & $\begin{array}{c}\text { Brillouin's } \\
\text { diversity } \\
\text { index }(\mathrm{H})\end{array}$ & $\begin{array}{c}\text { Maximum } \\
\text { diversity } \\
\text { (Hmax) }\end{array}$ & $\begin{array}{c}\text { Minimum } \\
\text { diversity } \\
\text { (Hmin) }\end{array}$ & $\begin{array}{c}\text { Evenness } \\
(\mathrm{E})\end{array}$ \\
\hline 1970 & 172 & 9 & 1.94 & 3.04 & 0.34 & 0.59 \\
1971 & 32 & 5 & 1.56 & 2.19 & .62 & .60 \\
1972 & 189 & 12 & 2.49 & 3.59 & .44 & .65 \\
1973 & 63 & 8 & 1.85 & 3.04 & .66 & .50 \\
1974 & 165 & 8 & 1.43 & 2.99 & .31 & .42 \\
1975 & -- & -- & - & - & - & - \\
1976 & 470 & 25 & 3.50 & 4.65 & .45 & .72 \\
1977 & 105 & 17 & 2.78 & 3.78 & 1.01 & .64 \\
1979 & 236 & 15 & 2.15 & 3.90 & .47 & .49 \\
1980 & 1,144 & 21 & 3.12 & 4.37 & .18 & .70 \\
1981 & 1,402 & 33 & 3.52 & 5.02 & .24 & .69 \\
1982 & 1,585 & 27 & 3.02 & 4.76 & .17 & .62 \\
1983 & 1,692 & 32 & 3.34 & 5.02 & .20 & .65 \\
1984 & 3,854 & 26 & 3.15 & 4.68 & .08 & .67 \\
1985 & 1,616 & 27 & 3.04 & 4.77 & .17 & .62 \\
1986 & 1,632 & 30 & 3.54 & 4.88 & .19 & .71 \\
1987 & 1,196 & 27 & 3.35 & 4.71 & .22 & .70 \\
1988 & 2,449 & 25 & 3.07 & 4.66 & .11 & .65 \\
\hline
\end{tabular}

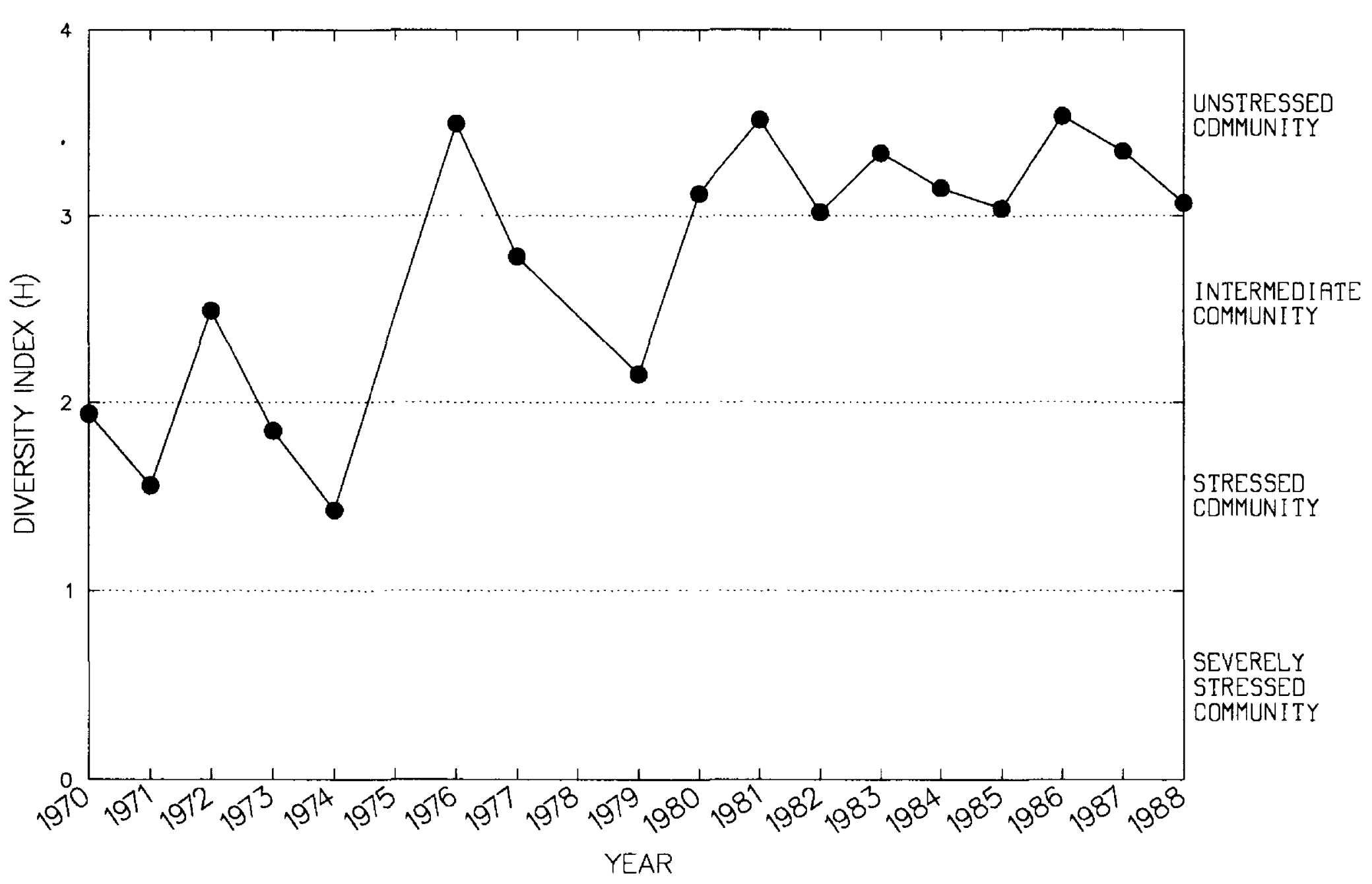


Slte 22

\begin{tabular}{ccccccc}
\hline Year & $\begin{array}{c}\text { Total } \\
\text { number of } \\
\text { organisms }\end{array}$ & $\begin{array}{c}\text { Total } \\
\text { number } \\
\text { of taxa }\end{array}$ & $\begin{array}{c}\text { Brillouin's } \\
\text { diversity } \\
\text { index (H) }\end{array}$ & $\begin{array}{c}\text { Maximum } \\
\text { diversity } \\
\text { (Hmax) }\end{array}$ & $\begin{array}{c}\text { Minimum } \\
\text { diversity } \\
\text { (Hmin) }\end{array}$ & $\begin{array}{c}\text { Evenness } \\
\text { (E) }\end{array}$ \\
\hline 1970 & 59 & 5 & 1.83 & 2.37 & 0.40 & 0.73 \\
1971 & 43 & 7 & 2.04 & 2.53 & .74 & .73 \\
1972 & 520 & 17 & 2.36 & 4.07 & .28 & .55 \\
1973 & 144 & 11 & 2.34 & 3.28 & .49 & .66 \\
1974 & 13 & 4 & 1.42 & 1.71 & .83 & .67 \\
1975 & - & - & - & - & -- &. \\
1976 & 703 & 21 & 2.41 & 4.36 & .27 & .52 \\
1977 & 162 & 12 & 2.34 & 3.52 & .50 & .61 \\
1979 & 179 & 10 & 1.57 & 3.37 & .37 & .40 \\
1980 & 247 & 16 & 2.77 & 3.92 & .48 & .67 \\
1981 & 323 & 25 & 3.44 & 4.68 & .62 & .70 \\
1982 & 465 & 20 & 3.32 & 4.23 & .36 & .77 \\
1983 & 319 & 22 & 3.20 & 4.39 & .54 & .69 \\
1984 & 516 & 21 & 3.21 & 4.36 & .35 & .71 \\
1985 & 247 & 13 & 3.21 & 3.54 & .38 & .89 \\
1986 & 340 & 21 & 3.17 & 4.25 & .49 & .71 \\
1987 & 1,307 & 33 & 3.47 & 5.03 & .25 & .57 \\
1988 & 1,027 & 19 & 3.06 & 4.18 & .18 & .72 \\
\hline
\end{tabular}

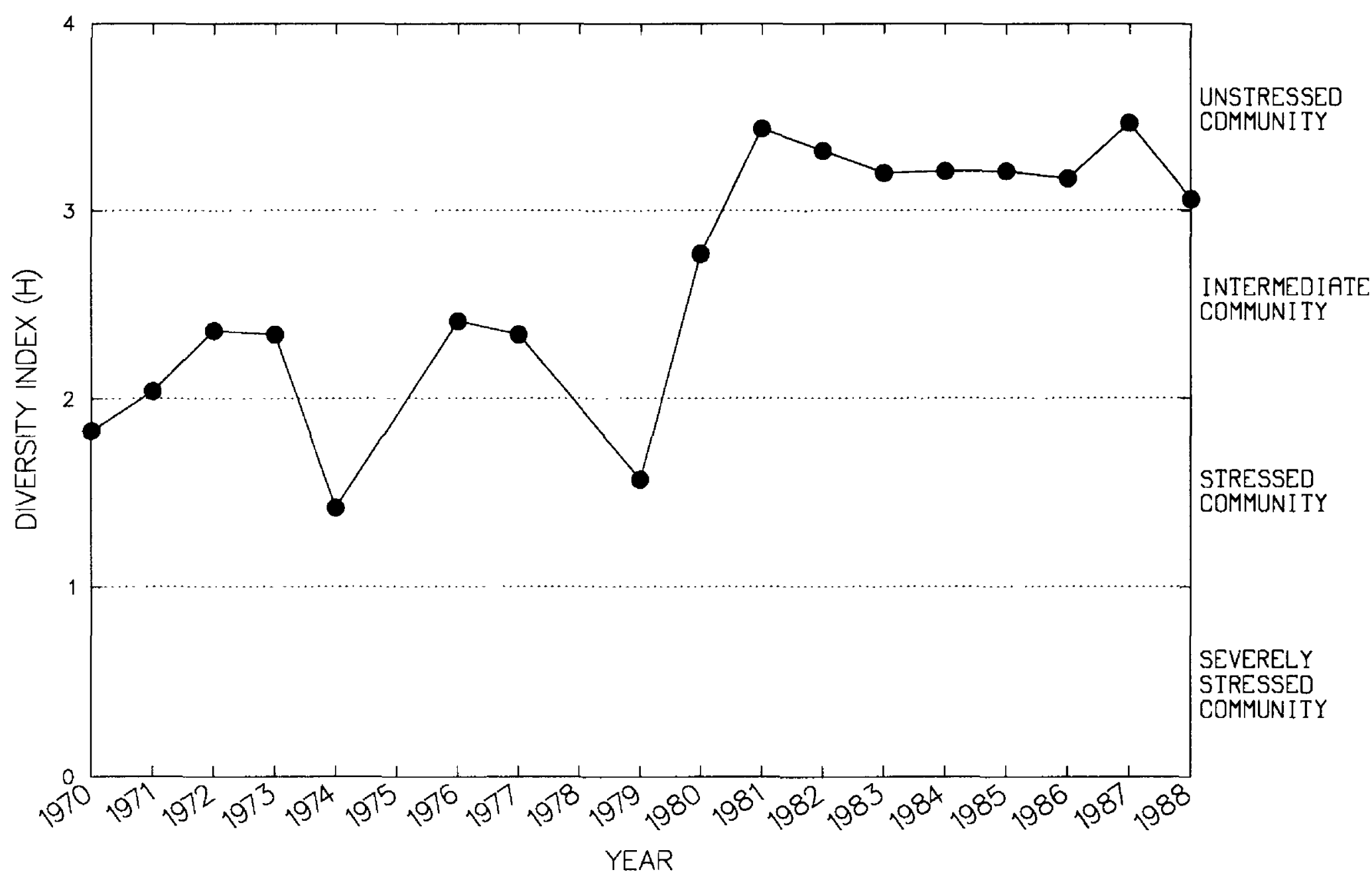


Site 23

\begin{tabular}{ccccccc}
\hline Year & $\begin{array}{c}\text { Total } \\
\text { number of } \\
\text { organisms }\end{array}$ & $\begin{array}{c}\text { Total } \\
\text { number } \\
\text { of taxa }\end{array}$ & $\begin{array}{c}\text { Brillouin's } \\
\text { diversity } \\
\text { index (H) }\end{array}$ & $\begin{array}{c}\text { Maximum } \\
\text { diversity } \\
\text { (Hmax) }\end{array}$ & $\begin{array}{c}\text { Minimum } \\
\text { diversity } \\
\text { (Hmin) }\end{array}$ & $\begin{array}{c}\text { Evenness } \\
\text { (E) }\end{array}$ \\
\hline 1970 & 83 & 4 & 1.87 & 2.04 & 0.23 & 0.90 \\
1971 & 24 & 4 & 1.39 & 1.71 & .57 & .72 \\
1972 & 299 & 10 & 1.93 & 3.36 & .25 & .54 \\
1973 & 234 & 5 & .97 & 2.35 & .13 & .38 \\
1974 & 73 & 6 & .88 & 2.44 & .42 & .23 \\
1975 & - & -- & - & - & - & - \\
1976 & 244 & 19 & 1.90 & 4.26 & .58 & .36 \\
1977 & 338 & 14 & 1.69 & 3.70 & .32 & .40 \\
1979 & 490 & 19 & 2.38 & 4.26 & .33 & .52 \\
1980 & 102 & 8 & 2.10 & 3.01 & .45 & .64 \\
1981 & 1,373 & 28 & 2.84 & 4.73 & .20 & .58 \\
1982 & 1,704 & 27 & 2.98 & 4.70 & .16 & .62 \\
1983 & 1,249 & 31 & 3.16 & 4.90 & .25 & .63 \\
1984 & 1,086 & 29 & 3.36 & 4.82 & .26 & .68 \\
1985 & 1.000 & 25 & 3.61 & 4.55 & .24 & .76 \\
1986 & 513 & 19 & 2.66 & 4.12 & .32 & .62 \\
1987 & 2,241 & 31 & 3.72 & 4.92 & .15 & .75 \\
1988 & 2,471 & 24 & 3.06 & 4.60 & .10 & .66 \\
\hline
\end{tabular}

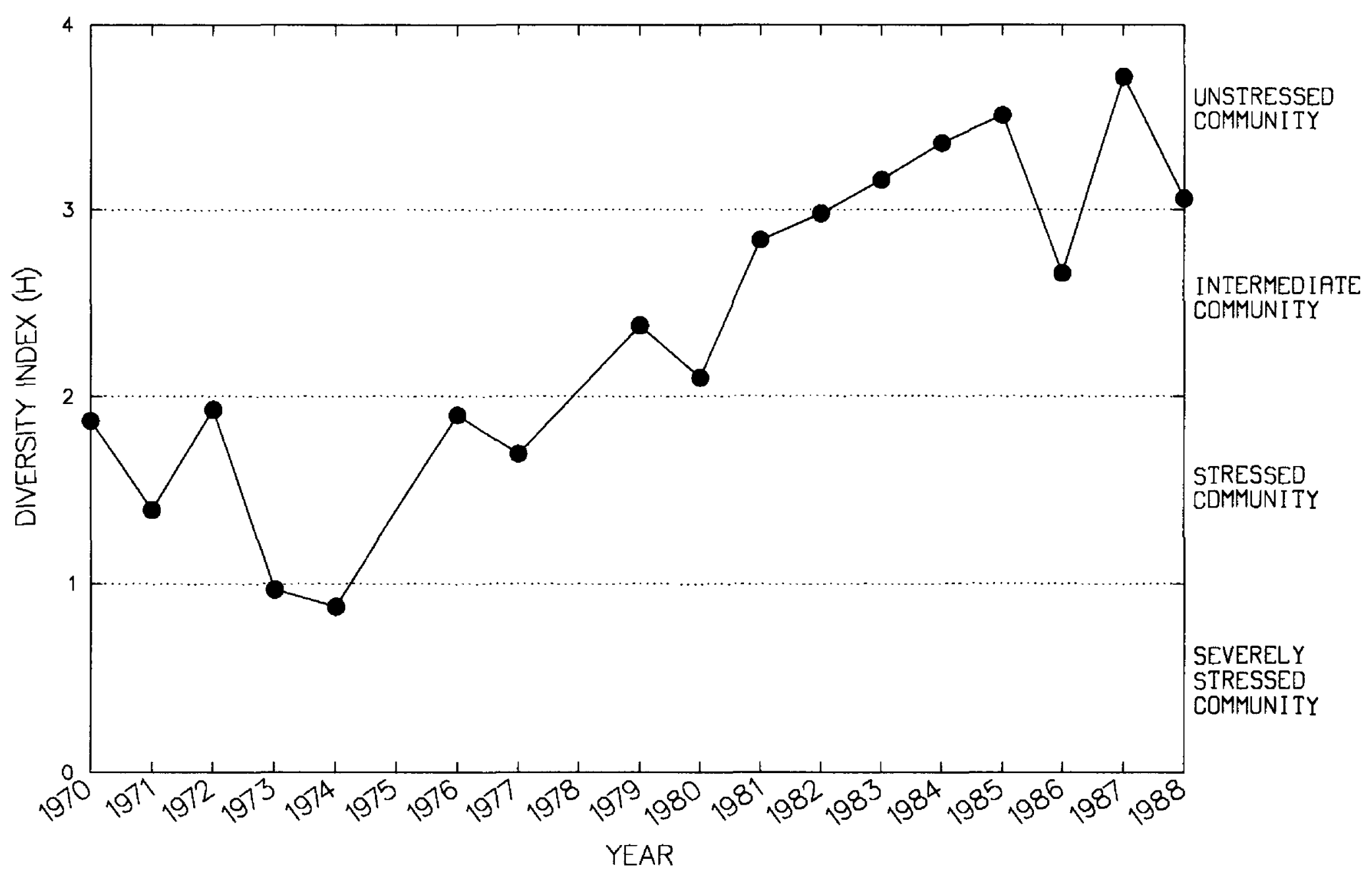


Site 24

\begin{tabular}{ccccccc}
\hline Year & $\begin{array}{c}\text { Total } \\
\text { number of } \\
\text { organisms }\end{array}$ & $\begin{array}{c}\text { Total } \\
\text { number } \\
\text { of taxa }\end{array}$ & $\begin{array}{c}\text { Brillouin's } \\
\text { diversity } \\
\text { index }(\mathrm{H})\end{array}$ & $\begin{array}{c}\text { Maximum } \\
\text { diversity } \\
\text { (Hmax) }\end{array}$ & $\begin{array}{c}\text { Minimum } \\
\text { diversity } \\
\text { (Hmin) }\end{array}$ & $\begin{array}{c}\text { Evenness } \\
\text { (E) }\end{array}$ \\
\hline 1970 & 55 & 1 & 0 & 0 & 0 & 0 \\
1971 & 156 & 5 & 1.32 & 2.26 & .19 & .54 \\
1972 & 901 & 11 & 1.64 & 3.48 & .11 & .45 \\
1973 & -- & - & - & - & - & - \\
1974 & 1,333 & 13 & 2.18 & 3.69 & .09 & .58 \\
1975 & -- & -- & - & - & - & - \\
1976 & 860 & 18 & 1.90 & 4.18 & .19 & .43 \\
1977 & 1,094 & 21 & 2.16 & 4.33 & .18 & .48 \\
1979 & 49 & 10 & 2.41 & 3.32 & 1.01 & .61 \\
1980 & 2,721 & 19 & 2.75 & 4.23 & .08 & .64 \\
1981 & 1,790 & 28 & 3.21 & 4.83 & .16 & .50 \\
1982 & 3,571 & 22 & 2.52 & 4.45 & .07 & .56 \\
1983 & 2,251 & 30 & 3.19 & 4.85 & .14 & .65 \\
1984 & 2,431 & 30 & 3.30 & 4.86 & .13 & .67 \\
1985 & 1,357 & 25 & 2.18 & 4.60 & .18 & .45 \\
1986 & 1,024 & 19 & 3.10 & 4.27 & .18 & .71 \\
1987 & 2,576 & 29 & 3.15 & 4.87 & .12 & .64 \\
1988 & 1,667 & 22 & 3.01 & 4.47 & .13 & .66 \\
\hline
\end{tabular}

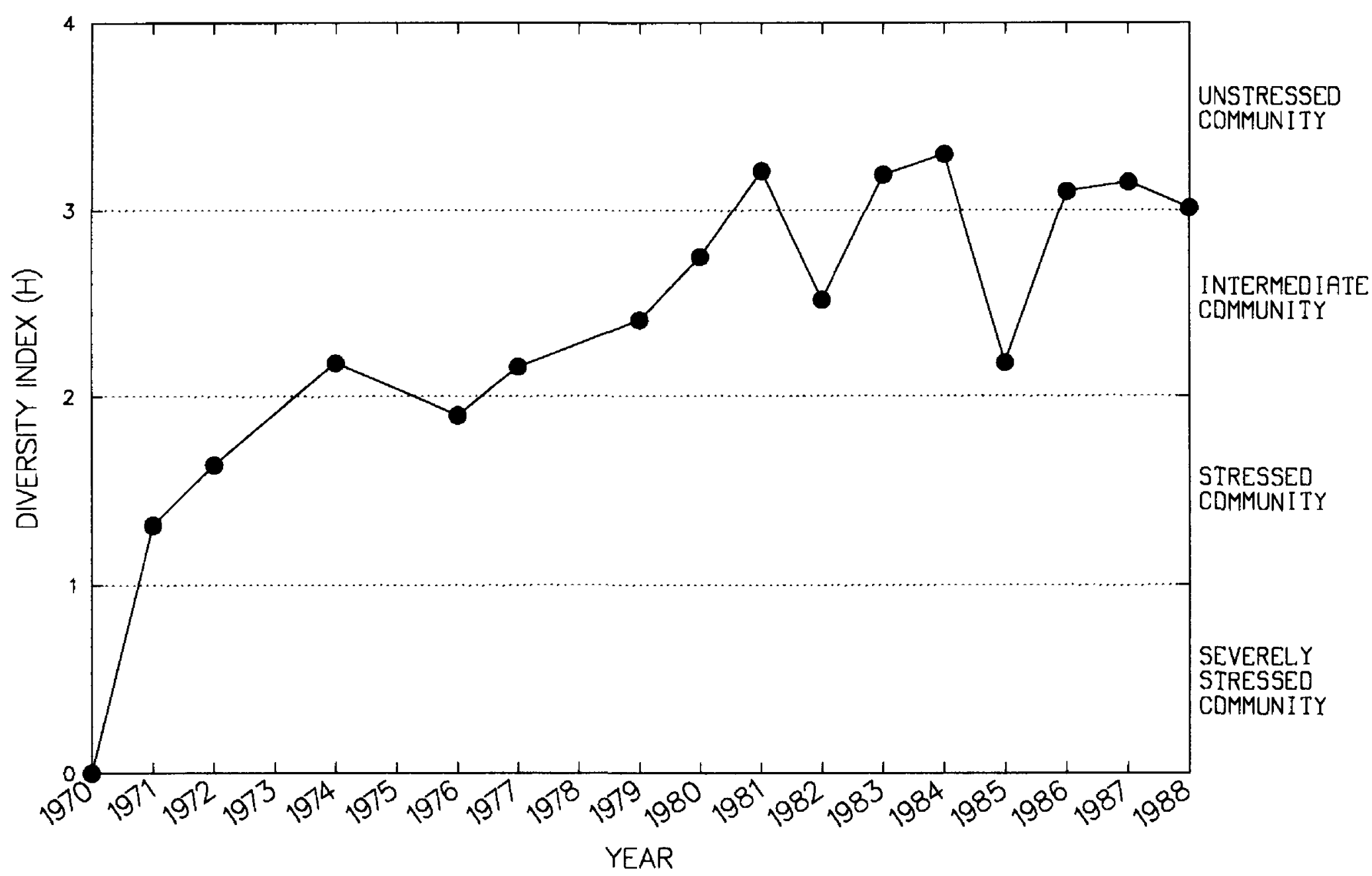


Site 26

\begin{tabular}{rcccccc}
\hline Year & $\begin{array}{c}\text { Total } \\
\text { number of } \\
\text { organisms }\end{array}$ & $\begin{array}{c}\text { Total } \\
\text { number } \\
\text { of taxa }\end{array}$ & $\begin{array}{c}\text { Brillouin's } \\
\text { diversity } \\
\text { index (H) }\end{array}$ & $\begin{array}{c}\text { Maximum } \\
\text { diversity } \\
\text { (Hmax) }\end{array}$ & $\begin{array}{c}\text { Minimum } \\
\text { diversity } \\
\text { (Hmin) }\end{array}$ & $\begin{array}{c}\text { Evenness } \\
\text { (E) }\end{array}$ \\
\hline 1970 & 61 & 2 & 0.25 & 1.03 & 0.10 & 0.16 \\
1971 & 7 & 3 & .77 & 1.33 & .77 & 0 \\
1972 & 181 & 5 & 1.52 & 2.27 & .17 & .64 \\
1973 & 473 & 12 & 1.34 & 3.55 & .21 & .34 \\
1974 & -- & - & - & - & - & - \\
1975 & -- & -- & - & - & - & - \\
1976 & 826 & 12 & 1.90 & 3.60 & .13 & .51 \\
1977 & 1,463 & 13 & 1.23 & 3.70 & .09 & .32 \\
1979 & 239 & 4 & .90 & 2.02 & .10 & .41 \\
1980 & 468 & 4 & .35 & 1.97 & .06 & .15 \\
1981 & 1,047 & 14 & 2.21 & 3.82 & .12 & .56 \\
1982 & 281 & 16 & 2.90 & 3.96 & .43 & .70 \\
1983 & 578 & 17 & 1.73 & 3.98 & .25 & .39 \\
1984 & 2,397 & 12 & .85 & 3.59 & .05 & .23 \\
1985 & 625 & 16 & 2.03 & 3.92 & .22 & .49 \\
1986 & 34 & 10 & 1.92 & 3.00 & 1.30 & .37 \\
1987 & 575 & 17 & 2.08 & 4.11 & .25 & .47 \\
1988 & 919 & 11 & 1.77 & 3.45 & .11 & .50 \\
\hline
\end{tabular}

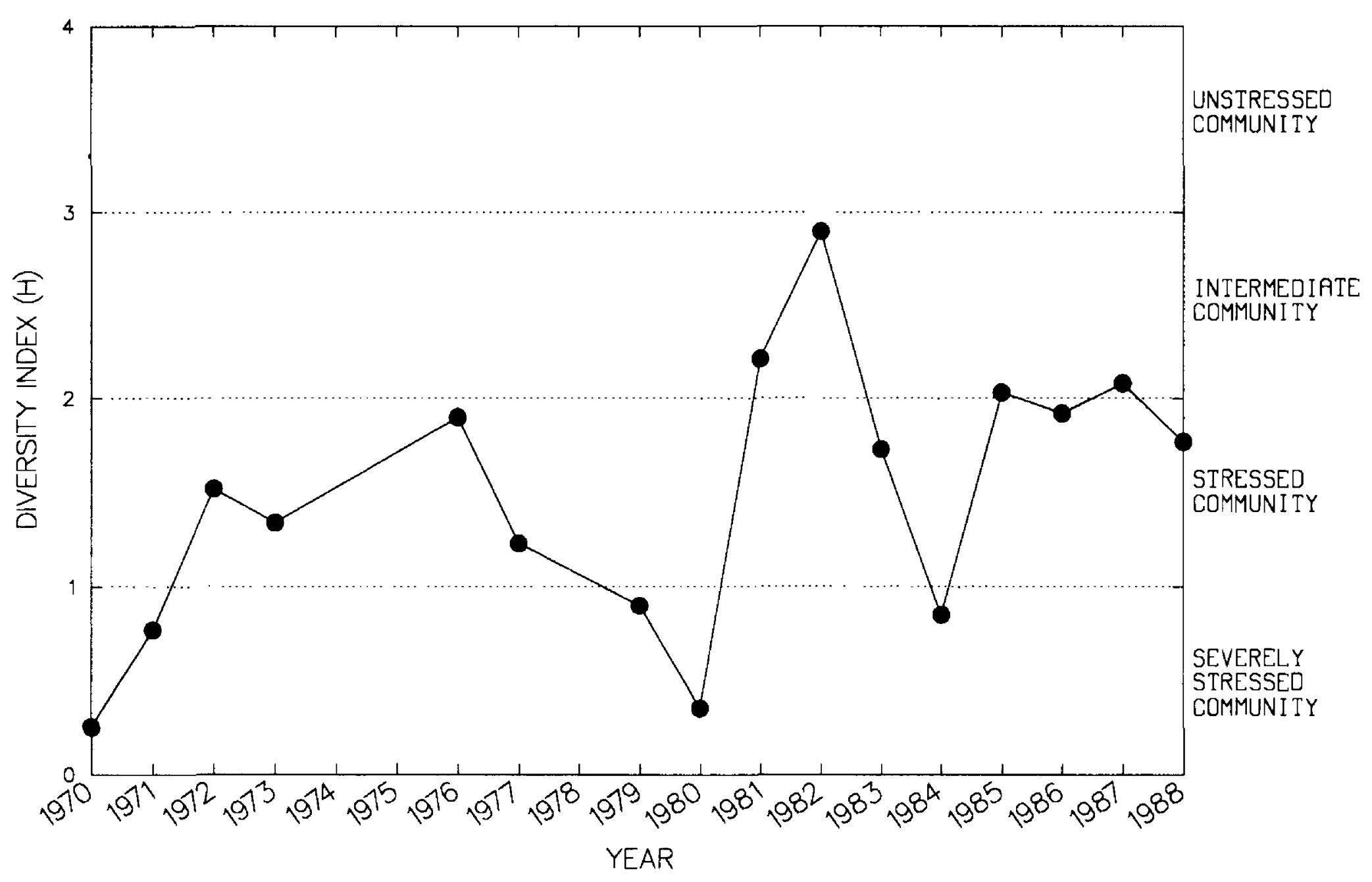


Slte 27

\begin{tabular}{ccccccc}
\hline Year & $\begin{array}{c}\text { Total } \\
\text { number of } \\
\text { organisms }\end{array}$ & $\begin{array}{c}\text { Total } \\
\text { number } \\
\text { of taxa }\end{array}$ & $\begin{array}{c}\text { Brillouin's } \\
\text { diversity } \\
\text { index }(H)\end{array}$ & $\begin{array}{c}\text { Maximum } \\
\text { diversity } \\
\text { (Hmax) }\end{array}$ & $\begin{array}{c}\text { Minimum } \\
\text { diversity } \\
\text { (Hmin) }\end{array}$ & $\begin{array}{c}\text { Evenness } \\
(\text { E) }\end{array}$ \\
\hline 1970 & 182 & 1 & 0 & 0 & 0 & 0 \\
1971 & 30 & 4 & 1.19 & 1.95 & .49 & .48 \\
1972 & 177 & 5 & .90 & 2.30 & .17 & .35 \\
1973 & 108 & 6 & 1.19 & 2.44 & .31 & .41 \\
1974 & -- & - & - & - & -- & - \\
1975 & 60 & 9 & 1.91 & 3.11 & .78 & .48 \\
1976 & 172 & 12 & 1.75 & 3.48 & .47 & .43 \\
1977 & 70 & 5 & 1.10 & 2.15 & .35 & .41 \\
1979 & 29 & 8 & 1.83 & 2.83 & 1.13 & .41 \\
1980 & 556 & 3 & 1.01 & 1.58 & .03 & .63 \\
1981 & 210 & 11 & 1.51 & 3.32 & .37 & .39 \\
1982 & 776 & 13 & 2.42 & 3.71 & .15 & .64 \\
1983 & 84 & 11 & 2.45 & 3.39 & .75 & .64 \\
1984 & 459 & 10 & 1.88 & 3.35 & .17 & .54 \\
1985 & 327 & 18 & 2.31 & 4.04 & .43 & .52 \\
1986 & 107 & 10 & 1.90 & 3.31 & .56 & .49 \\
1987 & 267 & 15 & 2.61 & 3.92 & .42 & .63 \\
1988 & 543 & 17 & 2.75 & 4.13 & .27 & .64 \\
\hline
\end{tabular}

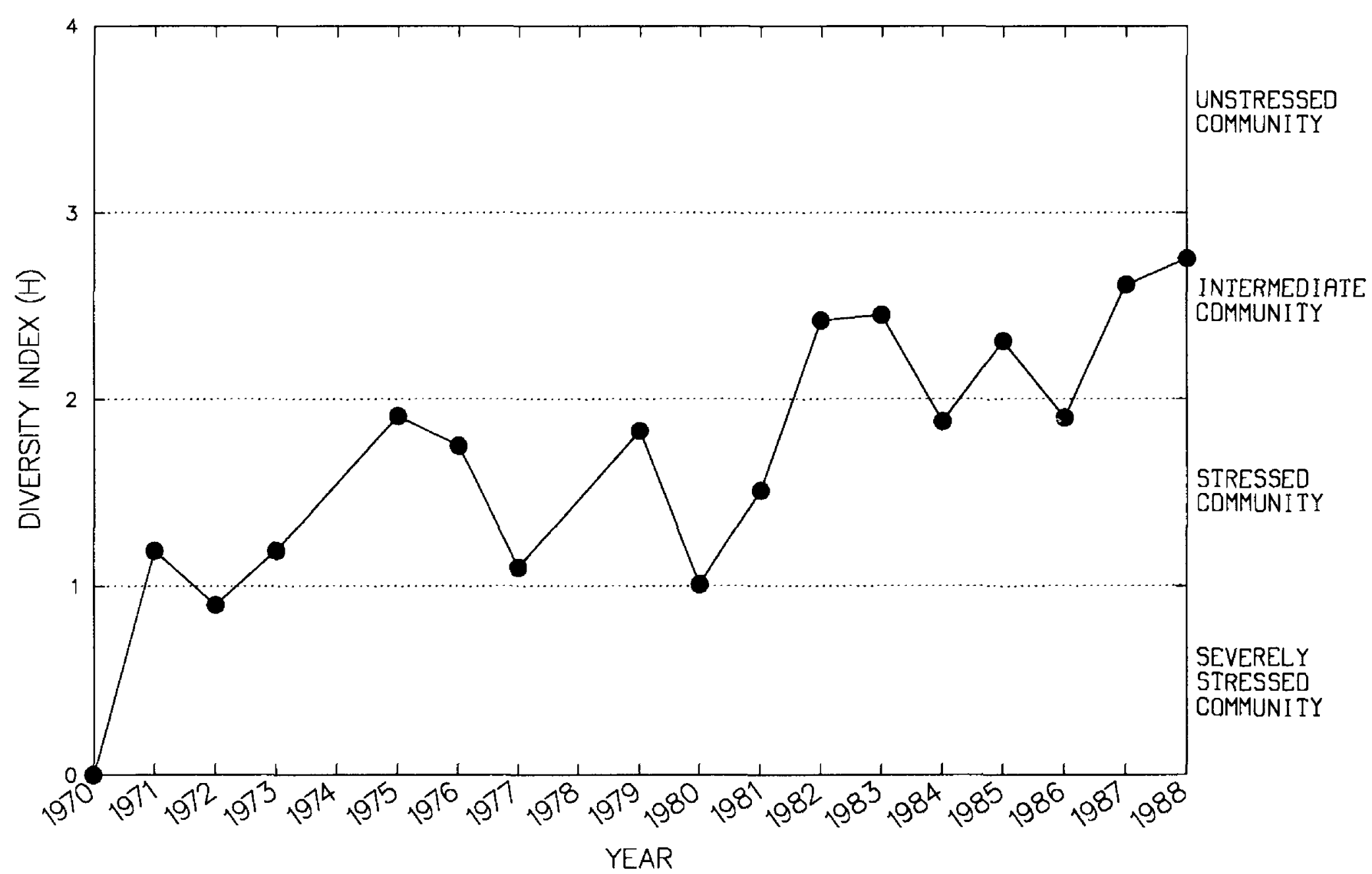


Site 28

\begin{tabular}{rcccccc}
\hline Year & $\begin{array}{c}\text { Total } \\
\text { number of } \\
\text { organisms }\end{array}$ & $\begin{array}{c}\text { Total } \\
\text { number } \\
\text { of taxa }\end{array}$ & $\begin{array}{c}\text { Brillouin's } \\
\text { diversity } \\
\text { index }(\mathrm{H})\end{array}$ & $\begin{array}{c}\text { Maximum } \\
\text { diversity } \\
\text { (Hmax) }\end{array}$ & $\begin{array}{c}\text { Minimum } \\
\text { diversity } \\
\text { (Hmin) }\end{array}$ & $\begin{array}{c}\text { Evenness } \\
\text { (E) }\end{array}$ \\
\hline 1970 & 76 & 4 & 0.87 & 1.88 & 0.25 & 0.38 \\
1971 & 26 & 6 & 2.04 & 2.34 & .88 & .79 \\
1972 & 202 & 10 & 2.18 & 3.22 & .34 & .64 \\
1973 & 293 & 10 & 2.34 & 3.26 & .25 & .70 \\
1974 & -- & -- & - & - & -- & - \\
1975 & -- & - & - & - & - & - \\
1976 & 820 & 18 & 3.05 & 4.16 & .20 & .72 \\
1977 & 935 & 23 & 2.65 & 4.52 & .23 & .56 \\
1979 & 855 & 27 & 3.45 & 4.75 & .30 & .71 \\
1980 & 1,188 & 17 & 2.91 & 4.11 & .14 & .70 \\
1981 & 836 & 18 & 3.06 & 4.14 & .20 & .73 \\
1982 & 1,298 & 23 & 2.74 & 4.50 & .18 & .59 \\
1983 & 1,358 & 18 & 2.56 & 4.15 & .13 & .60 \\
1984 & 928 & 16 & 1.96 & 3.93 & .16 & .48 \\
1985 & 1,007 & 21 & 2.51 & 4.42 & .20 & .55 \\
1986 & 1,026 & 19 & 2.33 & 4.18 & .18 & .54 \\
1987 & 4,216 & 19 & 2.02 & 4.26 & .05 & .47 \\
1988 & 2,599 & 19 & 2.31 & 4.26 & .08 & .53 \\
\hline
\end{tabular}

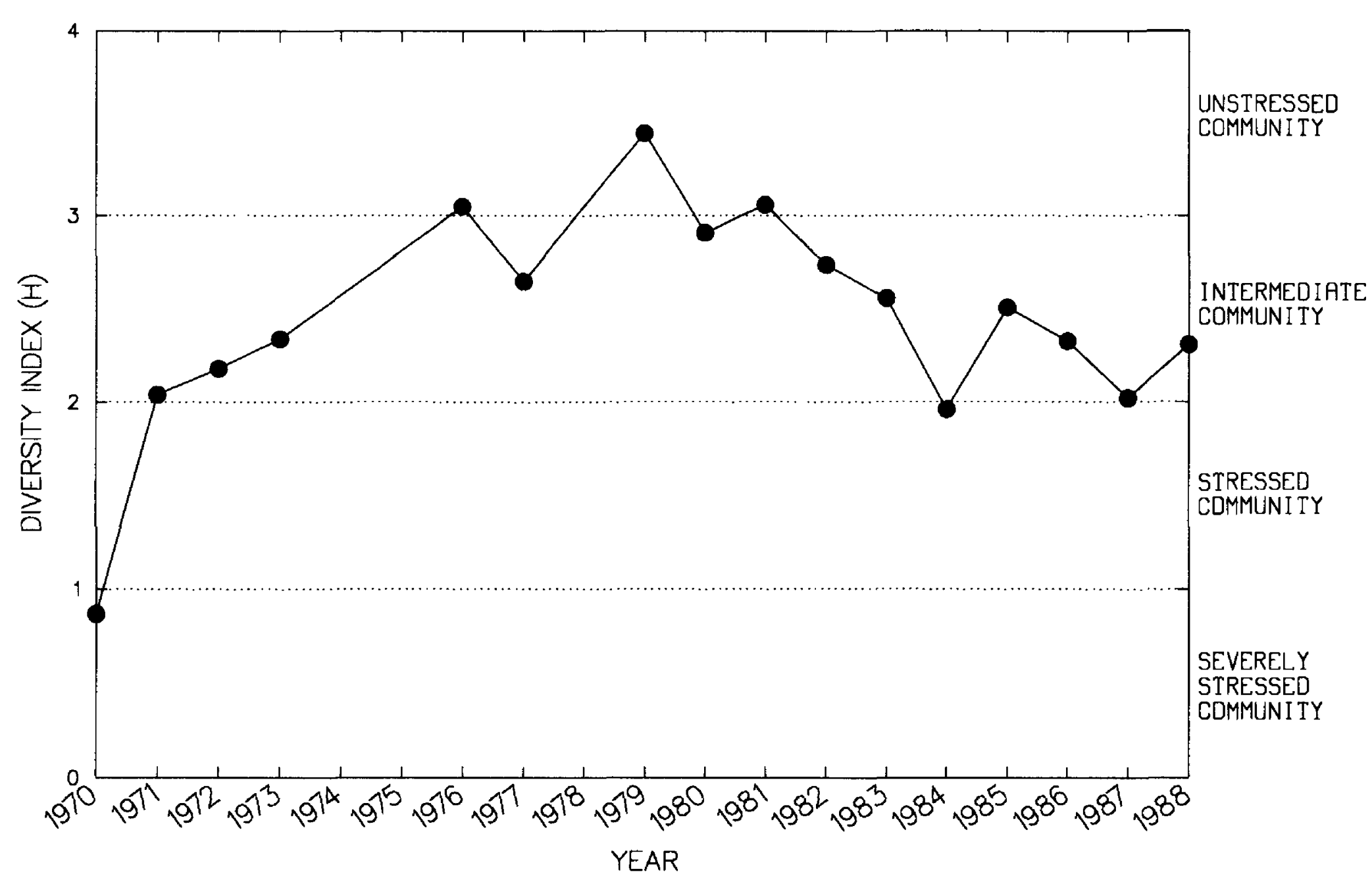




\section{Site 29}

\begin{tabular}{ccccccc}
\hline Year & $\begin{array}{c}\text { Total } \\
\text { number of } \\
\text { organisms }\end{array}$ & $\begin{array}{c}\text { Total } \\
\text { number } \\
\text { of taxa }\end{array}$ & $\begin{array}{c}\text { Brillouin's } \\
\text { diversity } \\
\text { index (H) }\end{array}$ & $\begin{array}{c}\text { Maximum } \\
\text { diversity } \\
\text { (Hmax) }\end{array}$ & $\begin{array}{c}\text { Minimum } \\
\text { diversity } \\
\text { (Hmin) }\end{array}$ & $\begin{array}{c}\text { Evenness } \\
\text { (E) }\end{array}$ \\
\hline 1970 & 61 & 6 & 0.95 & 2.42 & 0.48 & 0.24 \\
1971 & 13 & 3 & 1.05 & 1.44 & .56 & .55 \\
1972 & 677 & 15 & 2.25 & 3.84 & .19 & .56 \\
1973 & 290 & 6 & .85 & 2.56 & .14 & .29 \\
1974 & 156 & 6 & 1.44 & 2.48 & .23 & .54 \\
1975 & -- & - & - & - & - & - \\
1976 & 174 & 12 & 1.97 & 3.52 & .47 & .49 \\
1977 & 283 & 12 & 2.32 & 3.56 & .32 & .62 \\
1979 & 84 & 13 & 2.03 & 3.53 & .90 & .43 \\
1980 & 1,376 & 14 & 1.77 & 3.78 & .10 & .45 \\
1981 & 778 & 16 & 2.82 & 4.00 & .18 & .69 \\
1982 & 1,698 & 19 & 2.43 & 4.23 & .11 & .56 \\
1983 & 832 & 17 & 2.82 & 4.12 & .19 & .67 \\
1984 & 1,742 & 19 & 2.54 & 4.25 & .11 & .59 \\
1985 & 1,276 & 25 & 2.77 & 4.57 & .19 & .59 \\
1986 & 905 & 24 & 3.07 & 4.59 & .25 & .65 \\
1987 & 1,317 & 23 & 2.56 & 4.48 & .17 & .55 \\
1988 & 3,469 & 21 & 2.74 & 4.37 & .07 & .62 \\
\hline
\end{tabular}

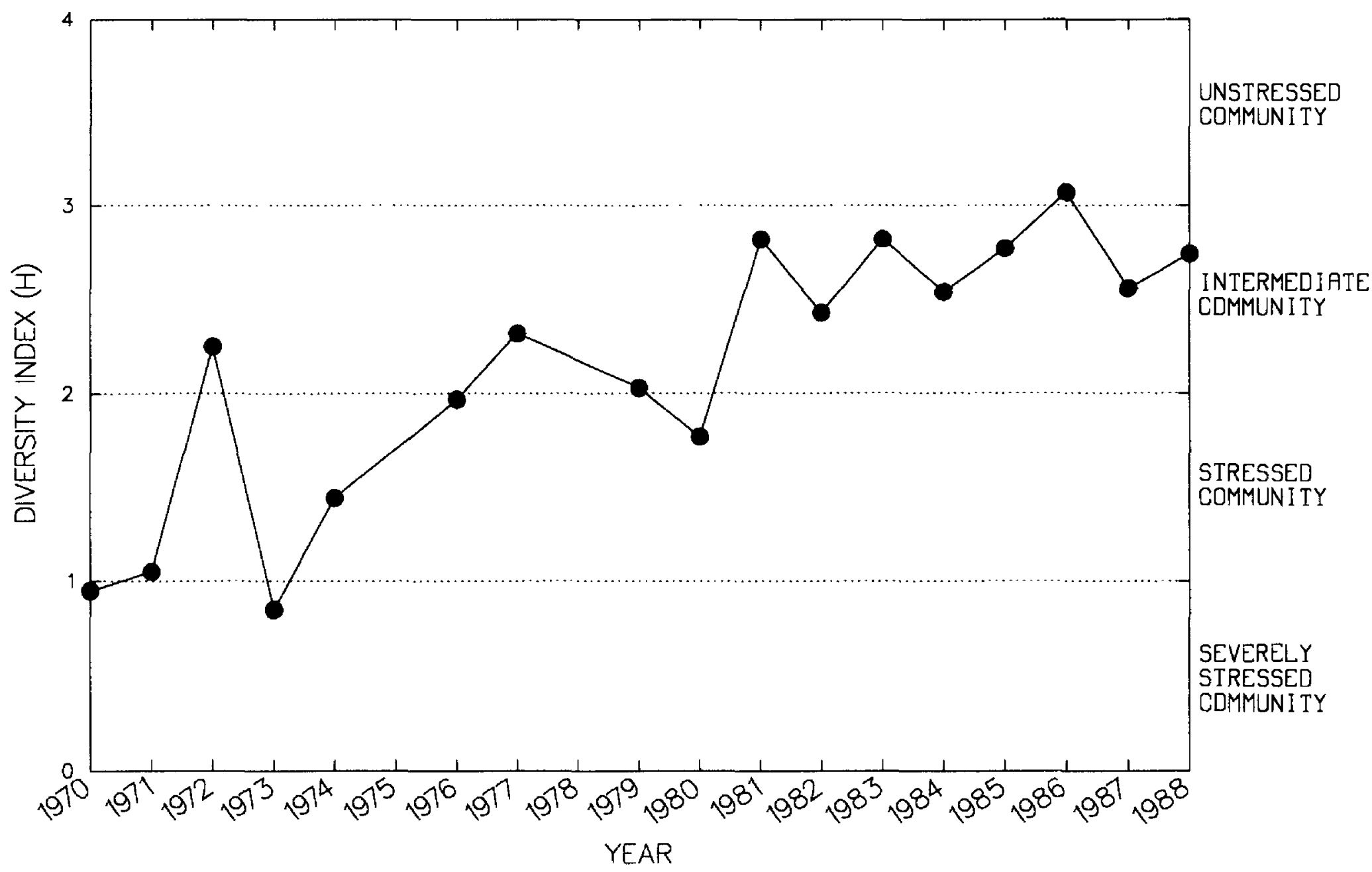


Slte 30

\begin{tabular}{ccccccc}
\hline Year & $\begin{array}{c}\text { Total } \\
\text { number of } \\
\text { organisms }\end{array}$ & $\begin{array}{c}\text { Total } \\
\text { number } \\
\text { of taxa }\end{array}$ & $\begin{array}{c}\text { Brillouin's } \\
\text { diversity } \\
\text { index }(\mathrm{H})\end{array}$ & $\begin{array}{c}\text { Maximum } \\
\text { diversity } \\
\text { (Hmax) }\end{array}$ & $\begin{array}{c}\text { Minimum } \\
\text { diversity } \\
\text { (Hmin) }\end{array}$ & $\begin{array}{c}\text { Evenness } \\
\text { (E) }\end{array}$ \\
\hline 1970 & 42 & 4 & 0.97 & 1.97 & 0.38 & 0.37 \\
1971 & -- & -- & - & - & - & - \\
1972 & 367 & 15 & 2.44 & 3.86 & .32 & .60 \\
1973 & 259 & 7 & 1.36 & 2.72 & .19 & .46 \\
1974 & -- & -- & - & - & - & - \\
1975 & 669 & 14 & 2.09 & 3.82 & .18 & .52 \\
1976 & 391 & 19 & 2.04 & 4.21 & .39 & .43 \\
1977 & 823 & 17 & 2.30 & 4.06 & .19 & .55 \\
1979 & 80 & 10 & 2.53 & 3.02 & .70 & .79 \\
1980 & 908 & 14 & 2.72 & 3.83 & .14 & .70 \\
1981 & 1,217 & 22 & 2.70 & 4.42 & .18 & .59 \\
1982 & 2,238 & 23 & 2.08 & 4.50 & .11 & .45 \\
1983 & 795 & 23 & 2.82 & 4.50 & .27 & .60 \\
1984 & 1,242 & 23 & 2.94 & 4.45 & .18 & .65 \\
1985 & 830 & 29 & 2.65 & 4.84 & .33 & .52 \\
1986 & 1,092 & 24 & 3.22 & 4.56 & .21 & .69 \\
1987 & 1,647 & 24 & 3.27 & 4.58 & .15 & .71 \\
1988 & 2,071 & 23 & 3.13 & 4.48 & .12 & .69 \\
\hline
\end{tabular}

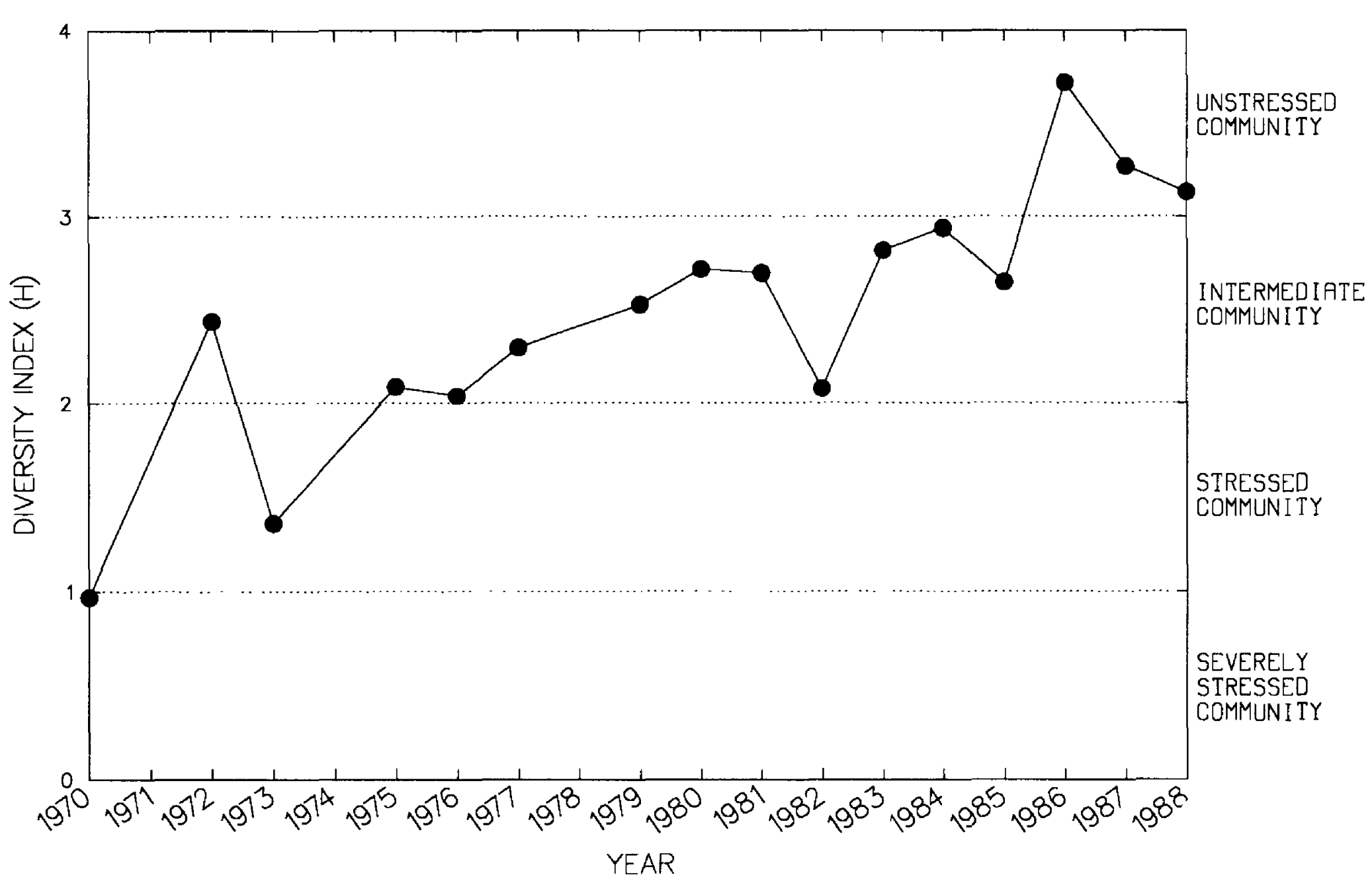


Site 31

\begin{tabular}{ccccccc}
\hline Year & $\begin{array}{c}\text { Total } \\
\text { number of } \\
\text { organisms }\end{array}$ & $\begin{array}{c}\text { Total } \\
\text { number } \\
\text { of taxa }\end{array}$ & $\begin{array}{c}\text { Brillouin's } \\
\text { diversity } \\
\text { index (H) }\end{array}$ & $\begin{array}{c}\text { Maximum } \\
\text { diversity } \\
\text { (Hmax) }\end{array}$ & $\begin{array}{c}\text { Minimum } \\
\text { diversity } \\
\text { (Hmin) }\end{array}$ & $\begin{array}{c}\text { Evenness } \\
\text { (E) }\end{array}$ \\
\hline 1970 & 69 & 1 & 0 & 0 & 0 & 0 \\
1971 & 6 & 3 & 1.08 & 1.08 & .82 & 1.0 \\
1972 & 325 & 14 & 3.71 & 1.92 & .33 & .47 \\
1973 & 43 & 6 & 2.36 & 1.76 & .62 & .65 \\
1974 & -- & -- & - & -- & -- & - \\
1975 & - & - & - & -- & -- & - \\
1976 & 199 & 19 & 4.14 & 3.77 & .68 & .89 \\
1977 & 1,005 & 20 & 4.27 & 2.60 & .19 & .59 \\
1979 & 37 & 9 & 2.76 & 2.21 & 1.09 & .67 \\
1980 & 972 & 18 & 4.10 & 3.12 & .17 & .75 \\
1981 & 847 & 25 & 2.55 & 4.67 & .28 & .52 \\
1982 & 1,413 & 26 & 2.84 & 4.66 & .18 & .59 \\
1983 & 1,174 & 23 & 3.01 & 4.45 & .19 & .66 \\
1984 & 1,215 & 25 & 2.85 & 4.63 & .26 & .60 \\
1985 & 549 & 22 & 2.42 & 4.50 & .35 & .50 \\
1986 & 846 & 20 & 2.79 & 4.27 & .22 & .63 \\
1987 & 1,640 & 21 & 2.41 & 4.35 & .13 & .54 \\
1988 & 1,351 & 26 & 2.90 & 4.73 & .19 & .60 \\
\hline
\end{tabular}

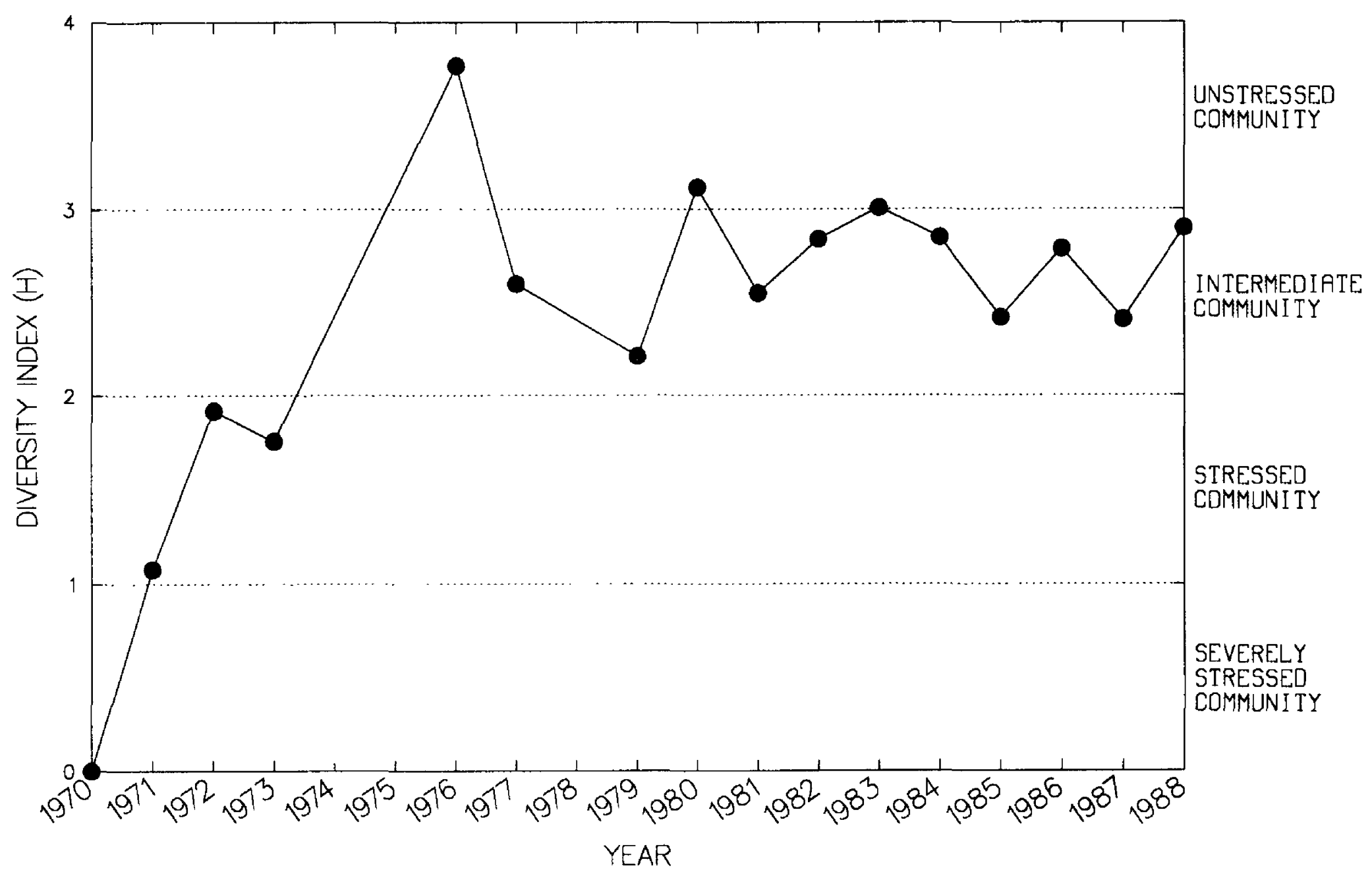


Site 32

\begin{tabular}{ccccccc}
\hline Year & $\begin{array}{c}\text { Total } \\
\text { number of } \\
\text { organisms }\end{array}$ & $\begin{array}{c}\text { Total } \\
\text { number } \\
\text { of taxa }\end{array}$ & $\begin{array}{c}\text { Brillouin's } \\
\text { diversity } \\
\text { index (H) }\end{array}$ & $\begin{array}{c}\text { Maximum } \\
\text { diversity } \\
\text { (Hmax) }\end{array}$ & $\begin{array}{c}\text { Minimum } \\
\text { diversity } \\
\text { (Hmin) }\end{array}$ & $\begin{array}{c}\text { Evenness } \\
\text { (E) }\end{array}$ \\
\hline 1970 & 104 & 4 & 1.83 & 1.90 & 0.19 & 0.96 \\
1971 & 15 & 4 & 1.34 & 1.99 & .76 & .47 \\
1972 & 921 & 17 & 2.11 & 4.04 & .17 & .50 \\
1973 & 441 & 11 & 1.36 & 3.38 & .20 & .37 \\
1974 & -- & -- & - & - & - & - \\
1975 & -- & - & - & - & - & - \\
1976 & 256 & 20 & 2.42 & 4.33 & .59 & .49 \\
1977 & 758 & 22 & 2.87 & 4.42 & .26 & .63 \\
1979 & -- & -- & - & - & - & - \\
1980 & 1,304 & 15 & 2.59 & 3.93 & .11 & .65 \\
1981 & 1,503 & 30 & 3.16 & 4.84 & .20 & .64 \\
1982 & 2,456 & 26 & 2.73 & 4.69 & .11 & .57 \\
1983 & 1,194 & 28 & 2.96 & 4.80 & .23 & .60 \\
1984 & 1,867 & 23 & 2.81 & 4.49 & .13 & .62 \\
1985 & 1,113 & 21 & 2.31 & 4.32 & .18 & .52 \\
1986 & 1,399 & 24 & 3.11 & 4.55 & .17 & .67 \\
1987 & 1,307 & 22 & 2.71 & 4.43 & .17 & .60 \\
1988 & 2,241 & 20 & 2.90 & 4.29 & .09 & .67 \\
\hline
\end{tabular}

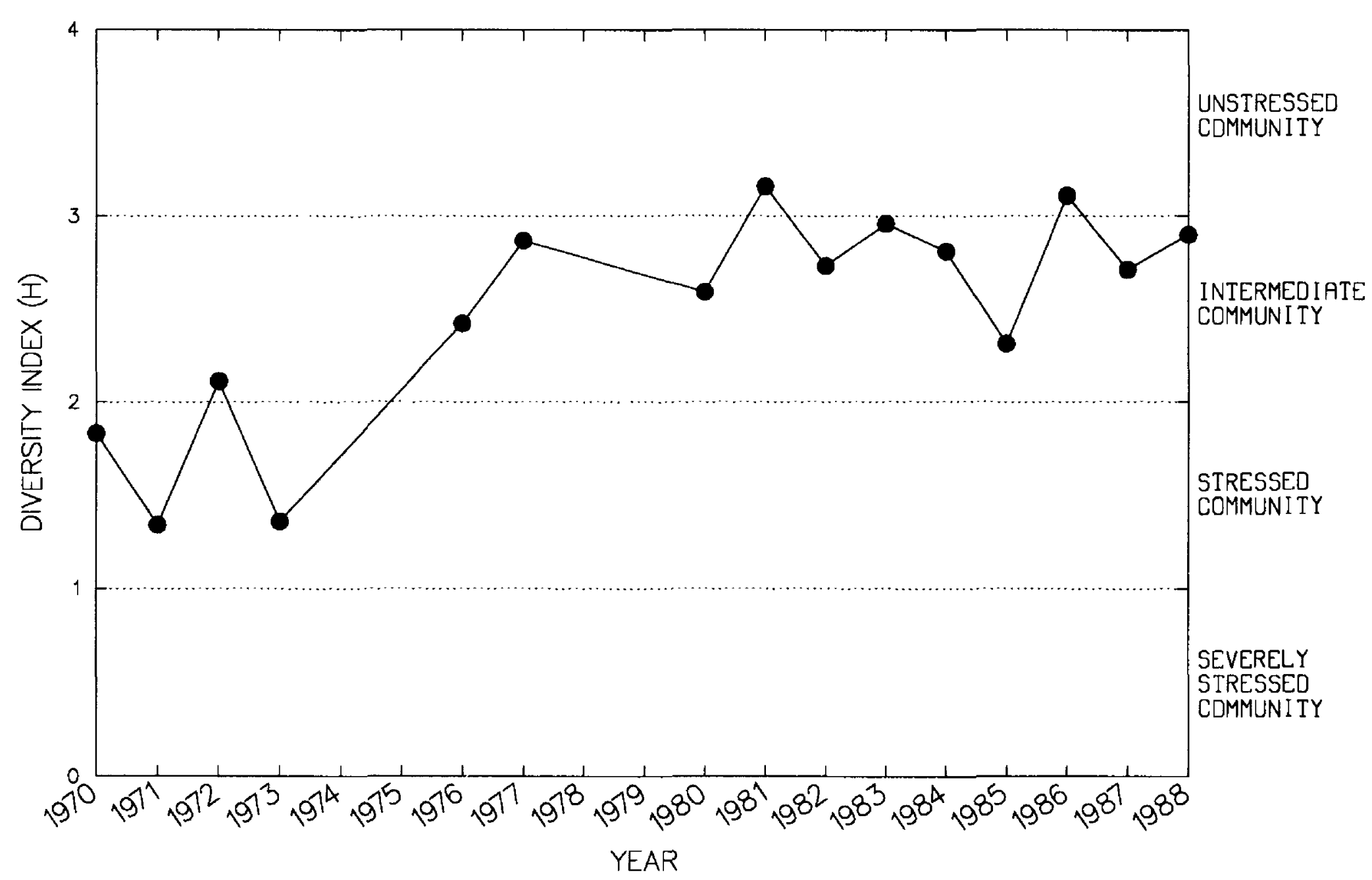


Site 33

\begin{tabular}{ccccccc}
\hline Year & $\begin{array}{c}\text { Total } \\
\text { number of } \\
\text { organisms }\end{array}$ & $\begin{array}{c}\text { Total } \\
\text { number } \\
\text { of taxa }\end{array}$ & $\begin{array}{c}\text { Brillouin's } \\
\text { diversity } \\
\text { index }(\mathrm{H})\end{array}$ & $\begin{array}{c}\text { Maximum } \\
\text { diversity } \\
\text { (Hmax) }\end{array}$ & $\begin{array}{c}\text { Mirimum } \\
\text { diversity } \\
\text { (Hmin) }\end{array}$ & $\begin{array}{c}\text { Evenness } \\
\text { (E) }\end{array}$ \\
\hline 1970 & 76 & 4 & 1.72 & 1.88 & 0.25 & 0.91 \\
1971 & 63 & 5 & 1.50 & 2.31 & .38 & .58 \\
1972 & 705 & 13 & 2.17 & 3.66 & .16 & .57 \\
1973 & 385 & 12 & 1.72 & 3.49 & .24 & .45 \\
1974 & 172 & 11 & 2.34 & 3.44 & .43 & .63 \\
1975 & - & - & - & - & - & - \\
1976 & - & - & - & - & - & - \\
1977 & 1,125 & 23 & 2.17 & 4.55 & .20 & .45 \\
1978 & - & - & - & - & - & - \\
1979 & 141 & 7 & 1.74 & 2.70 & .30 & .60 \\
1980 & 476 & 11 & 2.67 & 3.41 & .19 & .77 \\
1981 & 975 & 18 & 3.09 & 4.12 & .17 & .74 \\
1982 & 1,672 & 24 & 3.36 & 4.58 & .15 & .72 \\
1983 & 851 & 25 & 2.86 & 4.54 & .27 & .61 \\
1984 & 1,509 & 21 & 2.97 & 4.41 & .14 & .66 \\
1985 & 593 & 25 & 3.17 & 4.64 & .37 & .65 \\
1986 & 1,105 & 27 & 2.88 & 4.78 & .24 & .58 \\
1987 & 1,410 & 27 & 3.31 & 4.70 & .19 & .69 \\
1988 & 1,955 & 20 & 3.02 & 4.33 & .11 & .69 \\
\hline
\end{tabular}

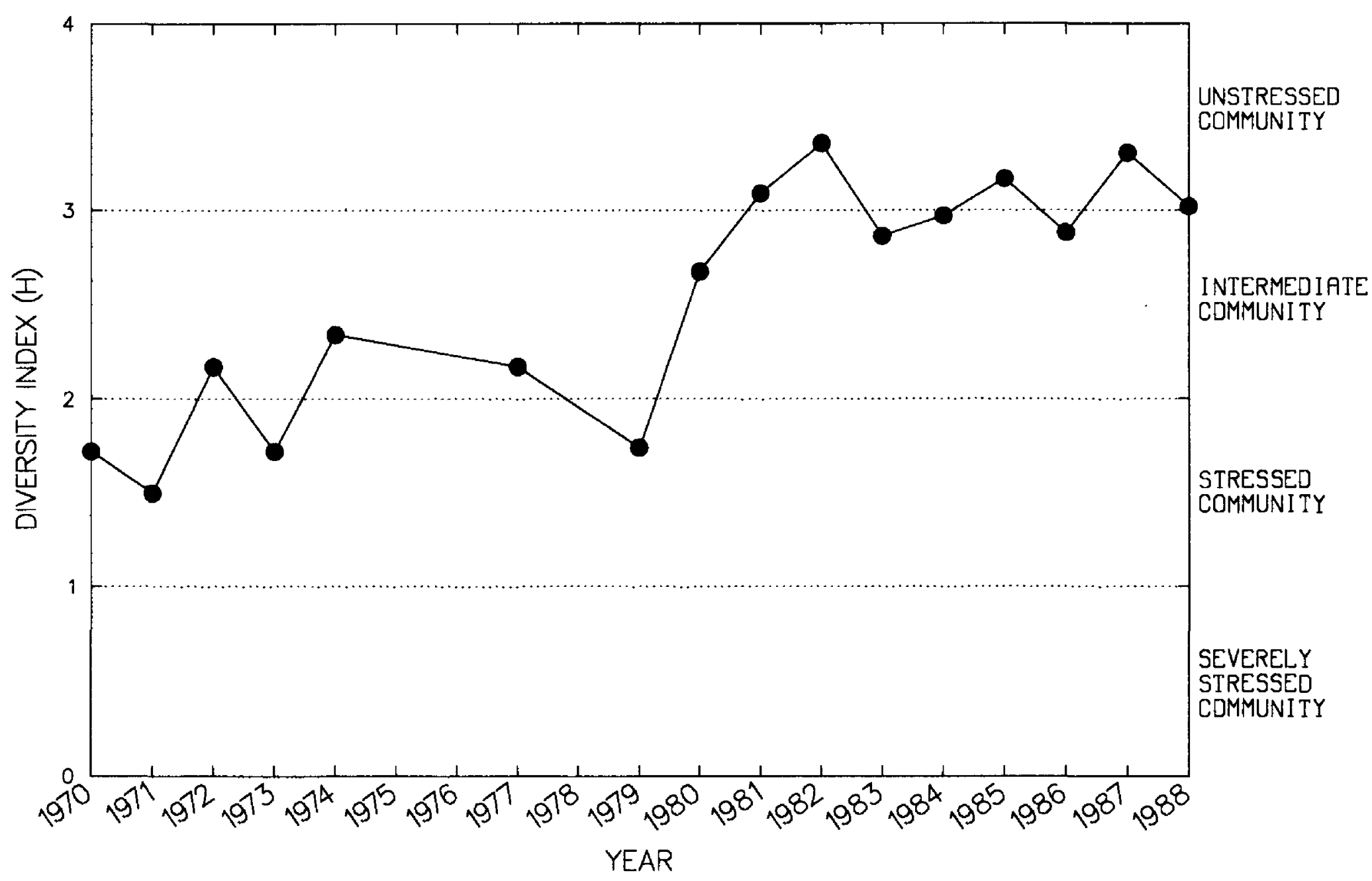


Site 34

\begin{tabular}{rcccccc}
\hline Year & $\begin{array}{c}\text { Total } \\
\text { number of } \\
\text { organisms }\end{array}$ & $\begin{array}{c}\text { Total } \\
\text { number } \\
\text { of taxa }\end{array}$ & $\begin{array}{c}\text { Brillouin's } \\
\text { diversity } \\
\text { index }(H)\end{array}$ & $\begin{array}{c}\text { Maximum } \\
\text { diversity } \\
\text { (Hmax) }\end{array}$ & $\begin{array}{c}\text { Minimum } \\
\text { diversity } \\
\text { (Hmin) }\end{array}$ & $\begin{array}{c}\text { Evenness } \\
\text { (E) }\end{array}$ \\
\hline 1970 & 77 & 5 & 2.01 & 2.27 & 0.32 & 0.87 \\
1971 & 5 & 2 & .66 & .98 & .46 & .39 \\
1972 & 334 & 14 & 2.37 & 3.84 & .33 & .58 \\
1973 & 136 & 7 & 1.59 & 2.76 & .31 & .52 \\
1974 & 130 & 7 & 1.25 & 2.79 & .32 & .38 \\
1975 & -- & -- & - & -- & -- & -- \\
1976 & -- & -- & -- & -- & -- & - \\
1977 & 768 & 19 & 3.04 & 4.21 & .22 & .71 \\
1979 & 13 & 6 & 1.48 & 2.04 & 1.33 & .22 \\
1980 & 1,288 & 12 & 2.33 & 3.57 & .09 & .64 \\
1981 & 2,184 & 21 & 3.12 & 4.35 & .10 & .71 \\
1982 & 2,495 & 32 & 3.37 & 5.02 & .14 & .66 \\
1983 & 937 & 23 & 2.97 & 4.53 & .23 & .64 \\
1984 & 2,250 & 30 & 2.90 & 4.85 & .14 & .59 \\
1985 & 965 & 28 & 3.12 & 4.77 & .28 & .63 \\
1986 & 776 & 23 & 3.16 & 4.53 & .27 & .68 \\
1987 & 2,309 & 31 & 3.54 & 4.94 & .15 & .71 \\
1988 & 2,901 & 24 & 3.28 & 4.60 & .09 & .71 \\
\hline
\end{tabular}

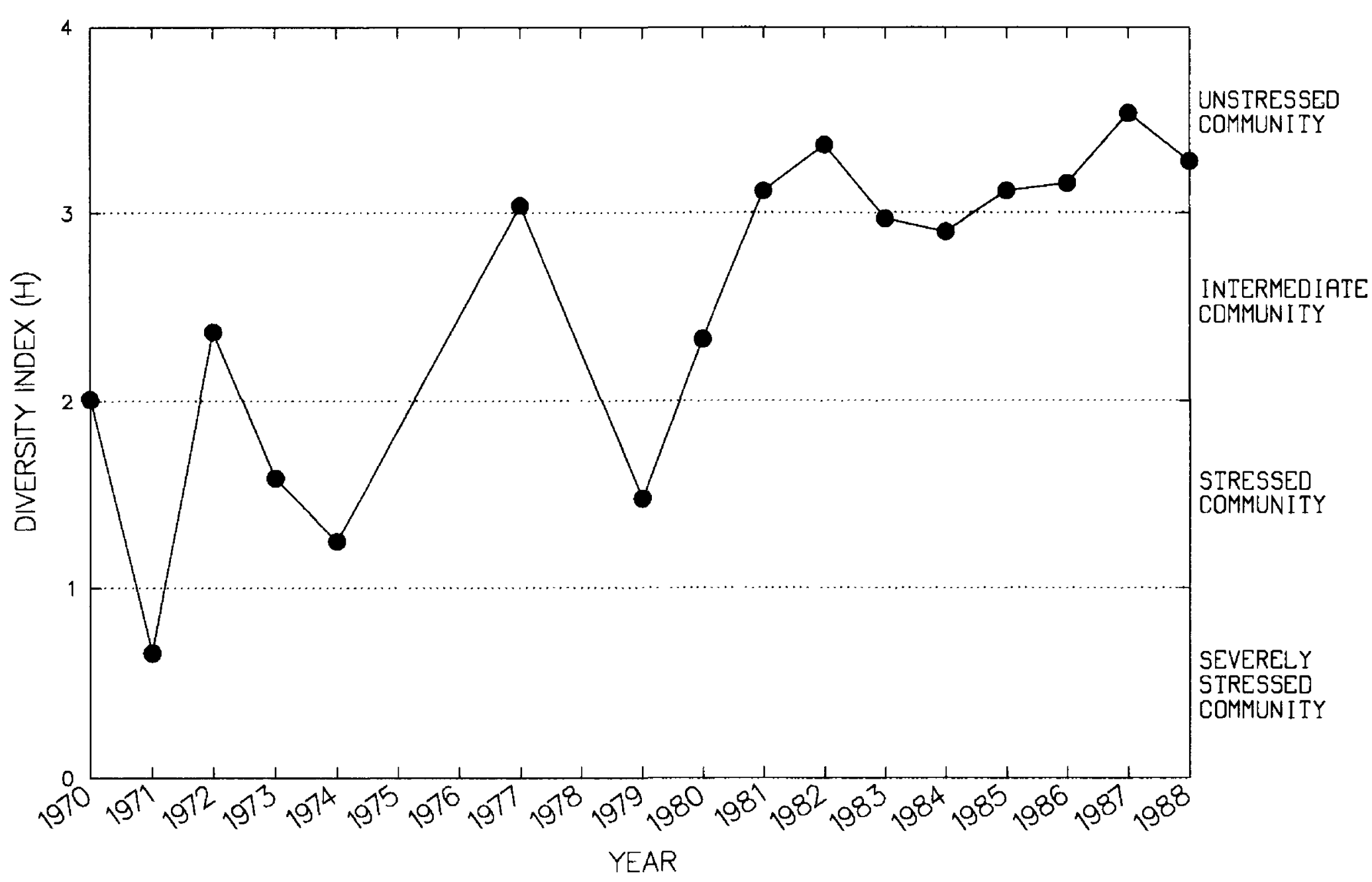


Site 35

\begin{tabular}{ccccccc}
\hline Year & $\begin{array}{c}\text { Total } \\
\text { number of } \\
\text { organisms }\end{array}$ & $\begin{array}{c}\text { Total } \\
\text { number } \\
\text { of taxa }\end{array}$ & $\begin{array}{c}\text { Brillouin's } \\
\text { diversity } \\
\text { index (H) }\end{array}$ & $\begin{array}{c}\text { Maximum } \\
\text { diversity } \\
\text { (Hmax) }\end{array}$ & $\begin{array}{c}\text { Minimum } \\
\text { diversity } \\
\text { (Hmin) }\end{array}$ & $\begin{array}{c}\text { Evenness } \\
\text { (E) }\end{array}$ \\
\hline 1970 & 102 & 5 & 1.78 & 2.28 & 0.26 & 0.75 \\
1971 & 43 & 4 & 1.65 & 2.05 & .38 & .76 \\
1972 & 858 & 14 & 1.60 & 3.77 & .15 & .40 \\
1973 & 138 & 6 & 1.59 & 2.46 & .26 & .60 \\
1974 & 140 & 12 & 2.20 & 3.56 & .56 & .55 \\
1975 & -- & - & - & - & - & - \\
1976 & 182 & 13 & 2.52 & 3.50 & .49 & .67 \\
1977 & 1,174 & 17 & 2.12 & 4.03 & .14 & .51 \\
1979 & 79 & 10 & 2.14 & 3.36 & .71 & .54 \\
1980 & 1,048 & 11 & 2.76 & 3.44 & .10 & .80 \\
1981 & 1,043 & 27 & 2.99 & 4.74 & .25 & .61 \\
1982 & 1,780 & 25 & 2.99 & 4.60 & .15 & .64 \\
\hline
\end{tabular}

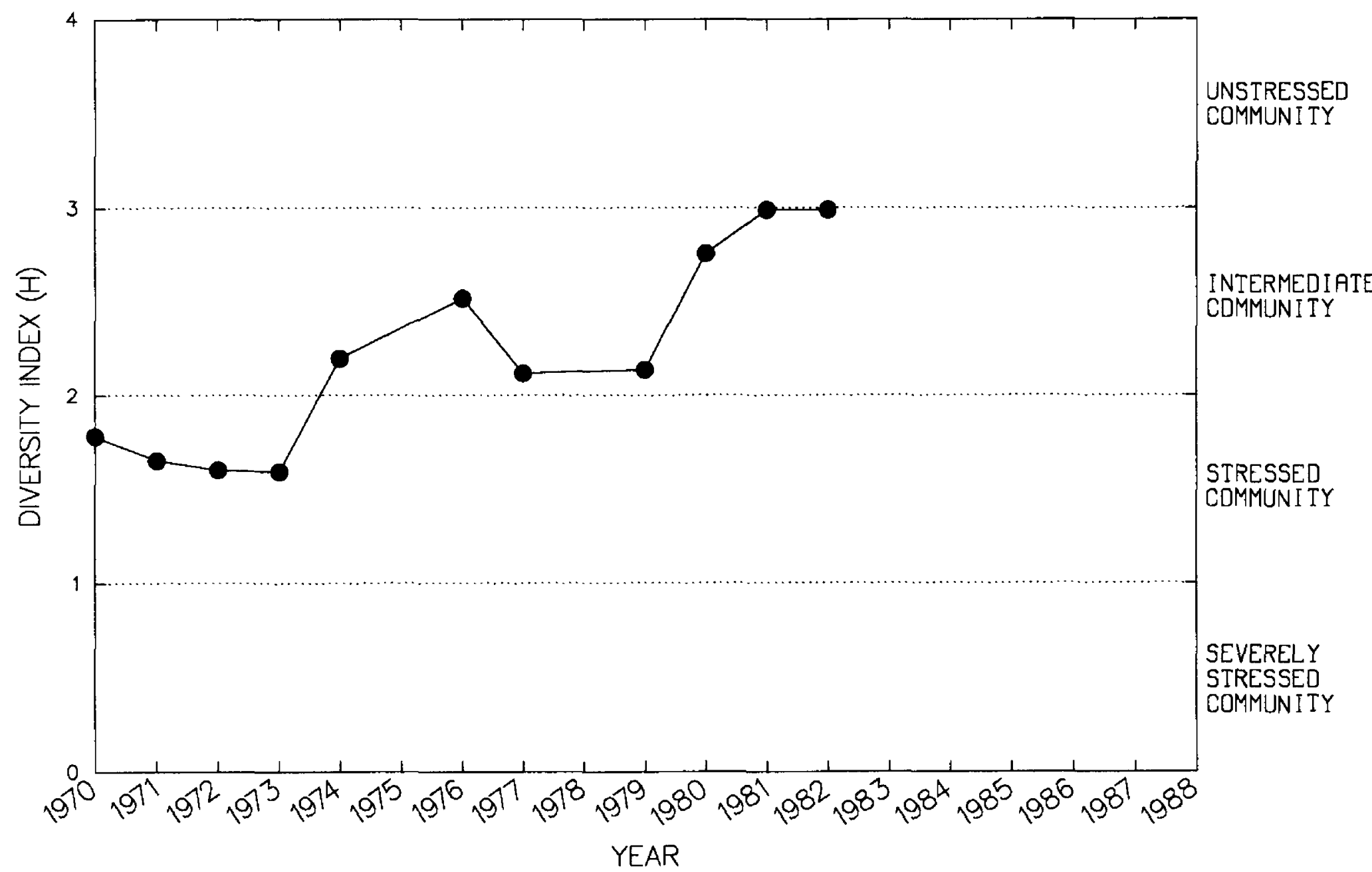


Slte 36

\begin{tabular}{ccccccc}
\hline Year & $\begin{array}{c}\text { Total } \\
\text { number of } \\
\text { organisms }\end{array}$ & $\begin{array}{c}\text { Total } \\
\text { number } \\
\text { of taxa }\end{array}$ & $\begin{array}{c}\text { Brillouin's } \\
\text { diversity } \\
\text { index (H) }\end{array}$ & $\begin{array}{c}\text { Maximum } \\
\text { diversity } \\
\text { (Hmax) }\end{array}$ & $\begin{array}{c}\text { Minimum } \\
\text { diversity } \\
\text { (Hmin) }\end{array}$ & $\begin{array}{c}\text { Evenness } \\
\text { (E) }\end{array}$ \\
\hline 1970 & 86 & 7 & 1.39 & 2.69 & 0.45 & 0.42 \\
1971 & 38 & 5 & 1.03 & 2.29 & .55 & .28 \\
1972 & 127 & 14 & 2.22 & 3.55 & $.7 \mathrm{i}$ & .53 \\
1973 & 201 & 13 & 1.93 & 3.63 & .45 & .46 \\
1974 & 147 & 14 & 1.67 & 3.72 & .63 & .34 \\
1975 & 357 & 21 & 2.61 & 4.21 & .47 & .57 \\
1976 & 685 & 29 & 2.66 & 4.83 & .38 & .51 \\
1977 & 325 & 24 & 2.97 & 4.52 & .59 & .61 \\
1979 & 55 & 10 & 1.80 & 3.16 & .93 & .39 \\
1980 & 3,840 & 14 & 2.64 & 3.80 & .04 & .69 \\
1981 & 2,454 & 28 & 2.65 & 4.81 & .12 & .54 \\
1982 & 1,798 & 22 & 2.34 & 4.46 & .13 & .51 \\
1983 & 2,839 & 31 & 2.84 & 4.95 & .12 & .56 \\
1984 & 5,952 & 33 & 2.13 & 5.03 & .07 & .42 \\
1985 & 1,852 & 30 & 3.06 & 4.91 & .17 & .61 \\
1986 & 2,233 & 31 & 2.92 & 4.90 & .15 & .58 \\
1987 & 2,184 & 31 & 3.06 & 4.93 & .15 & .61 \\
1988 & 1,498 & 24 & 2.65 & 4.56 & .16 & .57 \\
\hline
\end{tabular}

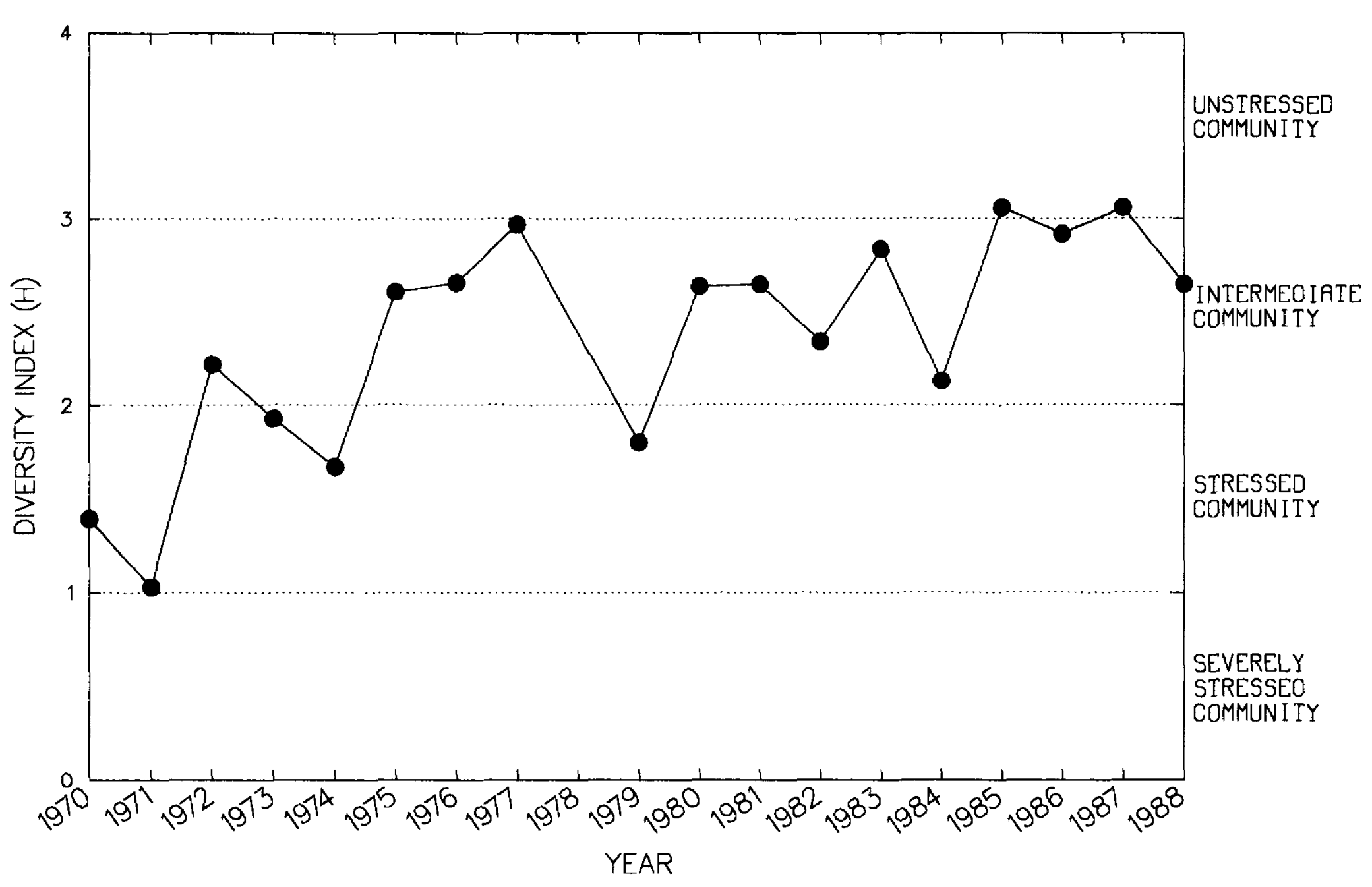


Site 37

\begin{tabular}{ccccccc}
\hline Year & $\begin{array}{c}\text { Total } \\
\text { number of } \\
\text { organisms }\end{array}$ & $\begin{array}{c}\text { Total } \\
\text { number } \\
\text { of taxa }\end{array}$ & $\begin{array}{c}\text { Brillouin's } \\
\text { diversity } \\
\text { index (H) }\end{array}$ & $\begin{array}{c}\text { Maximum } \\
\text { diversity } \\
\text { (Hmax) }\end{array}$ & $\begin{array}{c}\text { Minimum } \\
\text { diversity } \\
\text { (Hmin) }\end{array}$ & $\begin{array}{c}\text { Evenness } \\
\text { (E) }\end{array}$ \\
\hline 1970 & 66 & 7 & 1.75 & 2.71 & 0.54 & 0.55 \\
1971 & 20 & 2 & .81 & .87 & .22 & .90 \\
1972 & 128 & 14 & 2.56 & 3.57 & .70 & .65 \\
1973 & 117 & 16 & 2.48 & 3.79 & .87 & .55 \\
1974 & 113 & 7 & 1.40 & 2.68 & .36 & .45 \\
1975 & 40 & 7 & 1.89 & 2.77 & .78 & .56 \\
1976 & 266 & 20 & 2.96 & 4.19 & .57 & .66 \\
1977 & 221 & 15 & 2.79 & 3.90 & .49 & .67 \\
1979 & 77 & 9 & 1.33 & 3.09 & .64 & .28 \\
1980 & 468 & 19 & 3.01 & 4.23 & .34 & .68 \\
1981 & 559 & 29 & 3.36 & 4.75 & .46 & .68 \\
1982 & 1,074 & 31 & 3.28 & 4.94 & .28 & .64 \\
1983 & 1,242 & 31 & 2.36 & 4.87 & .25 & .46 \\
1984 & 1,051 & 30 & 2.95 & 4.81 & .28 & .59 \\
1985 & 1,704 & 32 & 3.20 & 4.95 & .20 & .63 \\
1986 & 647 & 34 & 3.66 & 4.92 & .47 & .72 \\
1987 & 1,278 & 36 & 2.95 & 5.14 & .28 & .55 \\
1988 & 1,190 & 28 & 2.68 & 4.78 & .23 & .54 \\
\hline
\end{tabular}

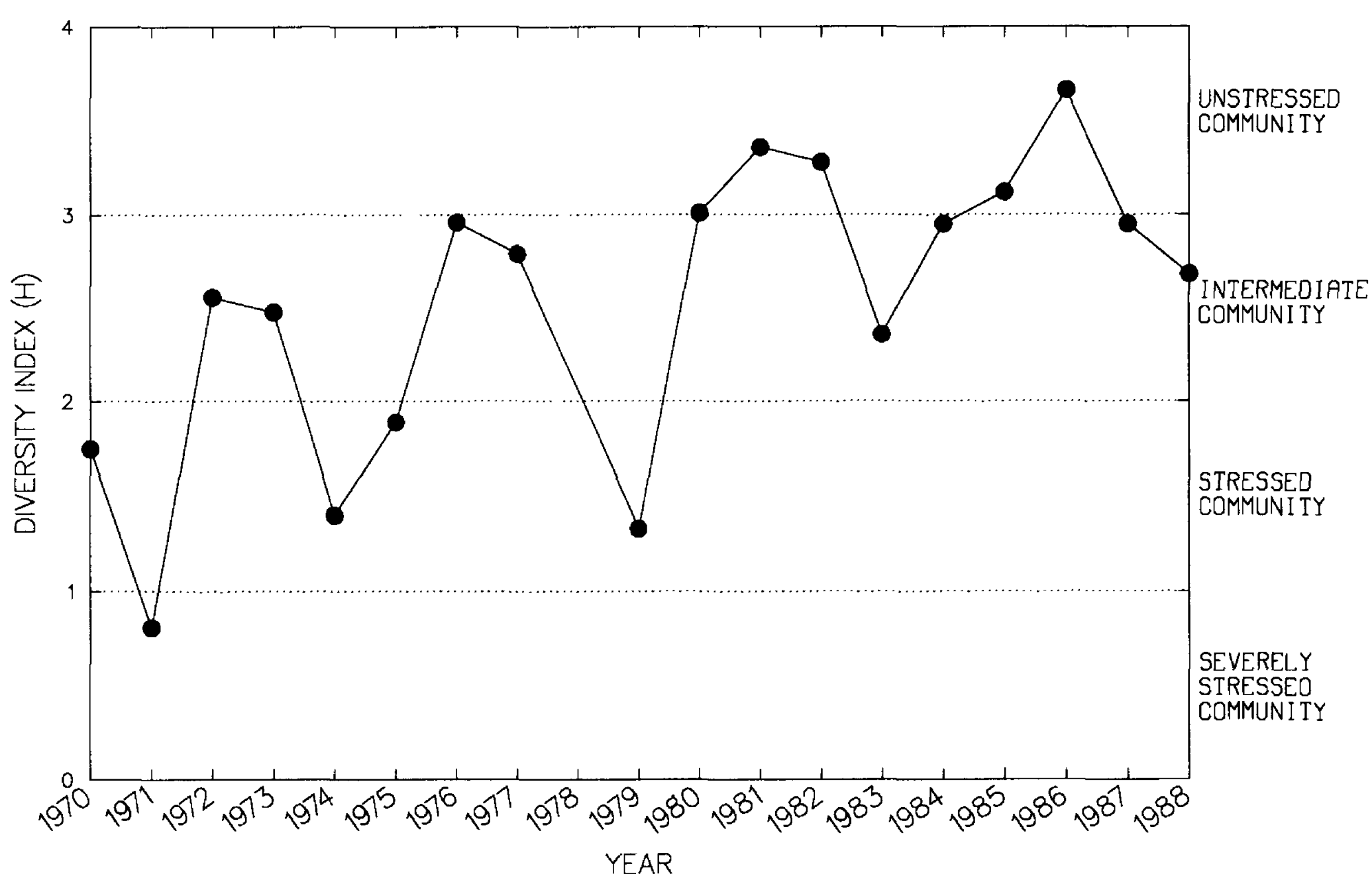


Site 38

\begin{tabular}{ccccccc}
\hline Year & $\begin{array}{c}\text { Total } \\
\text { number of } \\
\text { organisms }\end{array}$ & $\begin{array}{c}\text { Total } \\
\text { number } \\
\text { of taxa }\end{array}$ & $\begin{array}{c}\text { Brillouin's } \\
\text { diversity } \\
\text { index }(\mathrm{H})\end{array}$ & $\begin{array}{c}\text { Maximum } \\
\text { diversity } \\
\text { (Hmax) }\end{array}$ & $\begin{array}{c}\text { Minimum } \\
\text { diversity } \\
\text { (Hmin) }\end{array}$ & $\begin{array}{c}\text { Evenness } \\
\text { (E) }\end{array}$ \\
\hline 1970 & 58 & 2 & 0.18 & 0.94 & 0.10 & 0.10 \\
1971 & 26 & 2 & .83 & .90 & .18 & .91 \\
1972 & 507 & 11 & 1.55 & 3.39 & .18 & .43 \\
1973 & -- & -- & -- & - & - & - \\
1974 & -- & -- & - & - & - & - \\
1975 & 277 & 11 & 1.60 & 3.37 & .29 & .42 \\
1976 & 196 & 10 & 1.71 & 3.30 & .35 & .46 \\
1977 & 52 & 10 & 1.83 & 3.01 & .97 & .42 \\
1979 & 52 & 4 & .85 & 1.84 & .33 & .35 \\
1980 & 464 & 13 & 2.40 & 3.70 & .23 & .63 \\
1981 & 605 & 31 & 2.95 & 4.90 & .46 & .56 \\
1982 & 1,653 & 21 & 2.87 & 4.40 & .13 & .64 \\
1983 & 1,104 & 27 & 3.21 & 4.78 & .24 & .66 \\
1984 & 1,406 & 22 & 2.61 & 4.48 & .16 & .57 \\
1985 & 1,079 & 24 & 2.24 & 4.62 & .21 & .46 \\
1986 & 775 & 24 & 3.09 & 4.52 & .28 & .66 \\
$1987^{1}$ & 402 & 23 & 3.20 & 4.46 & .47 & .69 \\
1988 & 1,941 & 22 & 2.84 & 4.43 & .12 & .63 \\
\hline
\end{tabular}

${ }^{1}$ Sampled upstream riffle because of bridge construction.

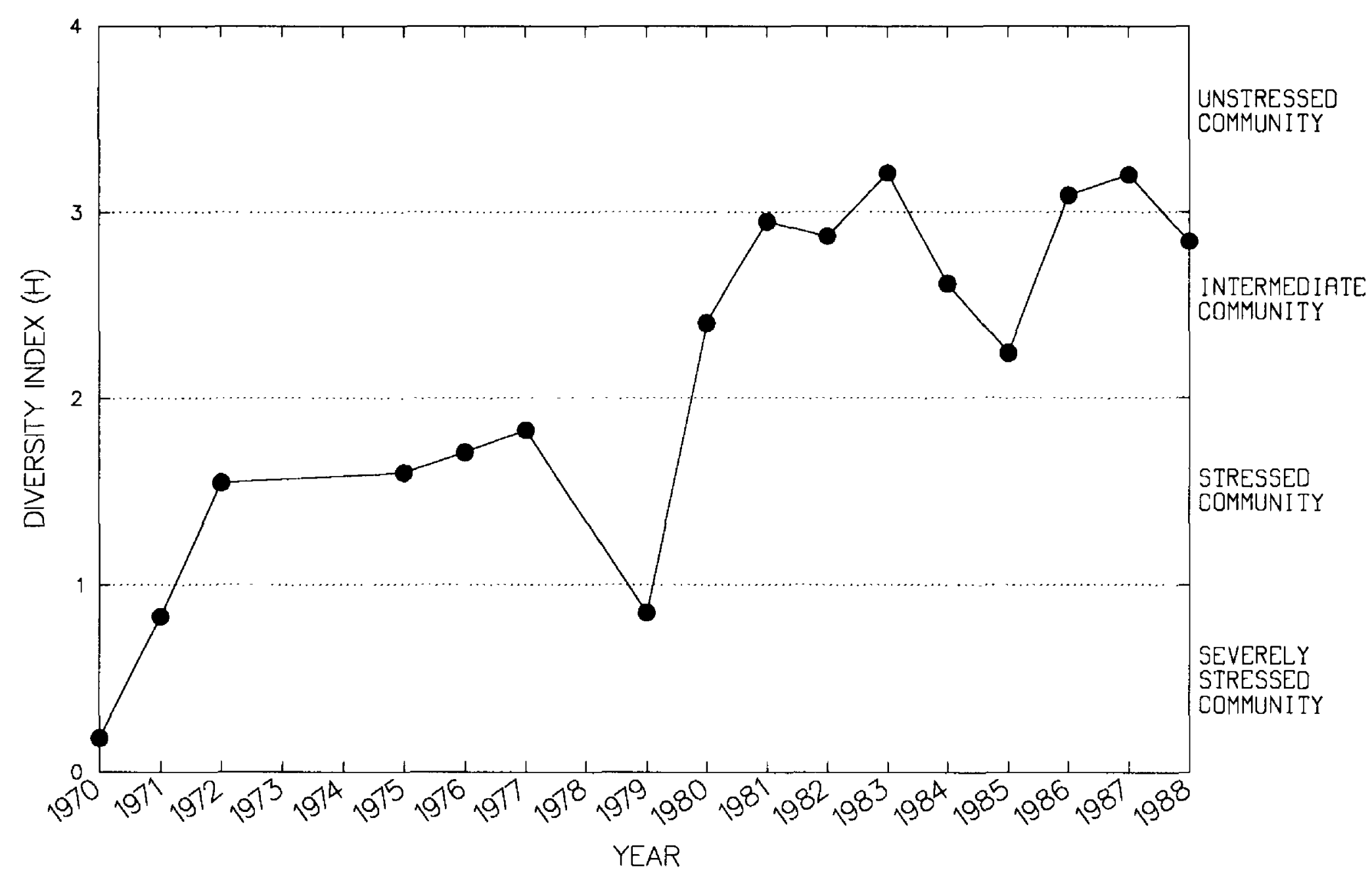


Site 39

\begin{tabular}{ccccccc}
\hline Year & $\begin{array}{c}\text { Total } \\
\text { number of } \\
\text { organisms }\end{array}$ & $\begin{array}{c}\text { Total } \\
\text { number } \\
\text { of taxa }\end{array}$ & $\begin{array}{c}\text { Brillouin's } \\
\text { diversity } \\
\text { index }(\mathrm{H})\end{array}$ & $\begin{array}{c}\text { Maximum } \\
\text { diversity } \\
\text { (Hmax) }\end{array}$ & $\begin{array}{c}\text { Minimum } \\
\text { diversity } \\
\text { (Hmin) }\end{array}$ & $\begin{array}{c}\text { Evenness } \\
\text { (E) }\end{array}$ \\
\hline 1979 & 1,455 & 18 & 2.58 & 4.18 & 0.12 & 0.60 \\
1980 & 238 & 16 & 2.98 & 4.03 & .49 & .70 \\
1981 & 639 & 30 & 3.62 & 4.81 & .42 & .73 \\
1982 & 2,814 & 36 & 3.49 & 5.13 & .14 & .67 \\
1983 & 766 & 36 & 3.49 & 5.07 & .44 & .66 \\
1984 & 3,044 & 42 & 3.06 & 5.37 & .16 & .56 \\
1985 & 701 & 27 & 3.00 & 4.80 & .35 & .60 \\
1986 & 2,581 & 44 & 3.22 & 5.46 & .19 & .57 \\
1987 & 1,110 & 40 & 3.64 & 5.32 & .35 & .66 \\
1988 & 1,354 & 28 & 3.29 & 4.77 & .21 & .68 \\
\hline
\end{tabular}

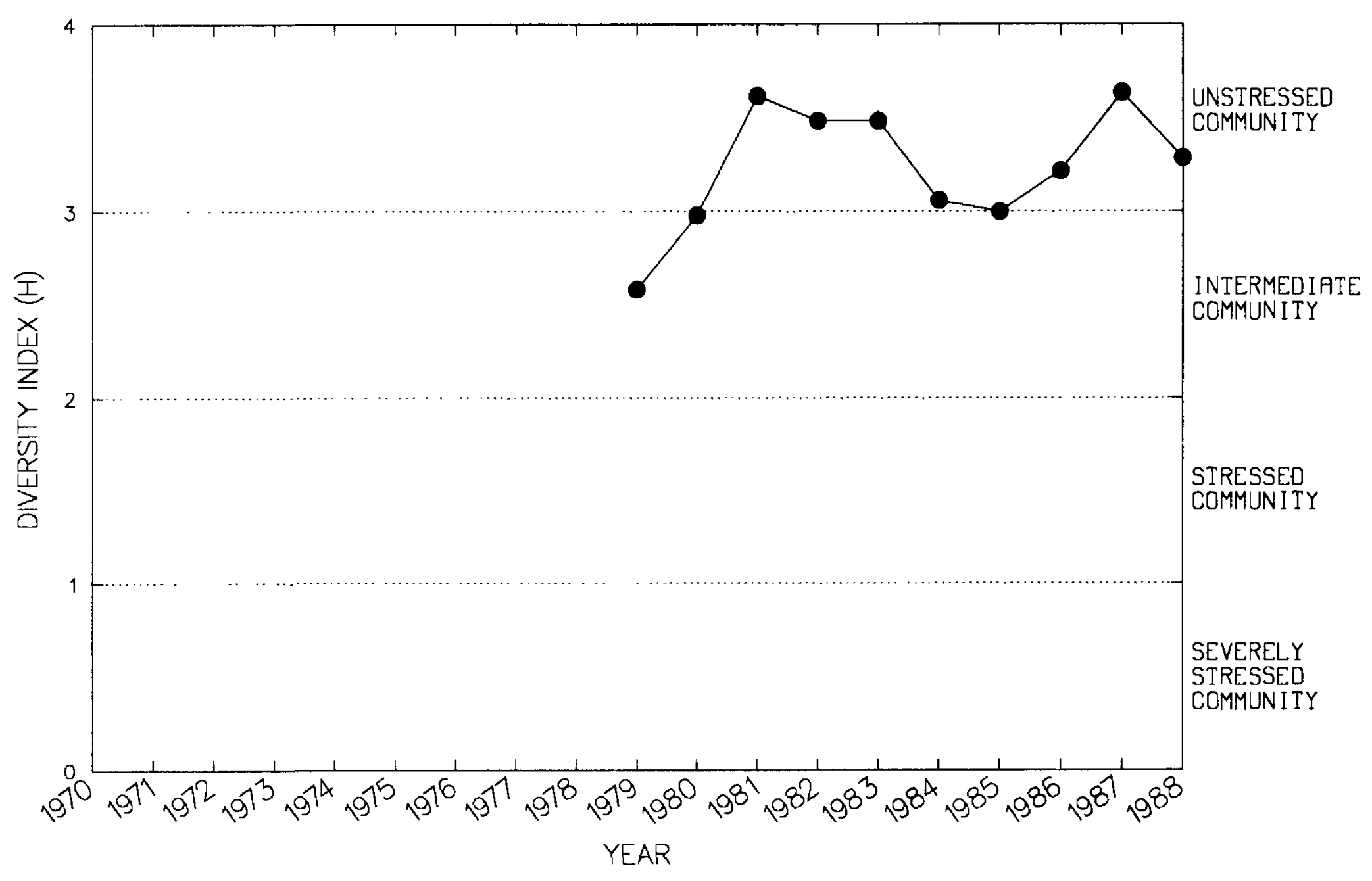


Site 40

\begin{tabular}{ccccccc}
\hline Year & $\begin{array}{c}\text { Total } \\
\text { number of } \\
\text { organisms }\end{array}$ & $\begin{array}{c}\text { Total } \\
\text { number } \\
\text { of taxa }\end{array}$ & $\begin{array}{c}\text { Brillouin's } \\
\text { diversity } \\
\text { index }(\mathrm{H})\end{array}$ & $\begin{array}{c}\text { Maximum } \\
\text { diversity } \\
\text { (Hmax) }\end{array}$ & $\begin{array}{c}\text { Minimum } \\
\text { diversity } \\
\text { (Hmin) }\end{array}$ & $\begin{array}{c}\text { Evenness } \\
\text { (E) }\end{array}$ \\
\hline 1970 & -- & -- & - & - & - & - \\
1971 & - & - & - & - & - & - \\
1972 & 133 & 8 & 1.77 & 2.99 & 0.37 & 0.53 \\
1973 & 653 & 11 & 1.34 & 3.43 & .14 & .36 \\
1974 & 246 & 10 & 1.66 & 3.31 & .29 & .46 \\
1975 & 717 & 16 & 1.74 & 4.02 & .20 & .40 \\
1976 & 460 & 13 & 2.08 & 3.66 & .23 & .54 \\
1977 & 103 & 15 & 2.48 & 3.91 & .90 & .53 \\
1979 & 132 & 18 & 3.13 & 3.96 & .90 & .73 \\
1980 & 549 & 10 & 2.53 & 3.35 & .15 & .74 \\
1981 & 650 & 23 & 3.28 & 4.45 & .32 & .72 \\
1982 & 1,663 & 30 & 3.28 & 4.88 & .19 & .66 \\
1983 & 1,016 & 32 & 3.23 & 5.00 & .30 & .62 \\
1984 & 1,441 & 24 & 2.86 & 4.52 & .17 & .62 \\
1985 & 999 & 25 & 3.41 & 4.68 & .24 & .72 \\
1986 & 428 & 36 & 3.92 & 5.19 & .71 & .72 \\
1987 & 1,049 & 37 & 3.53 & 5.14 & .34 & .66 \\
1988 & 1,819 & 25 & 3.64 & 4.65 & .14 & .78 \\
\hline
\end{tabular}

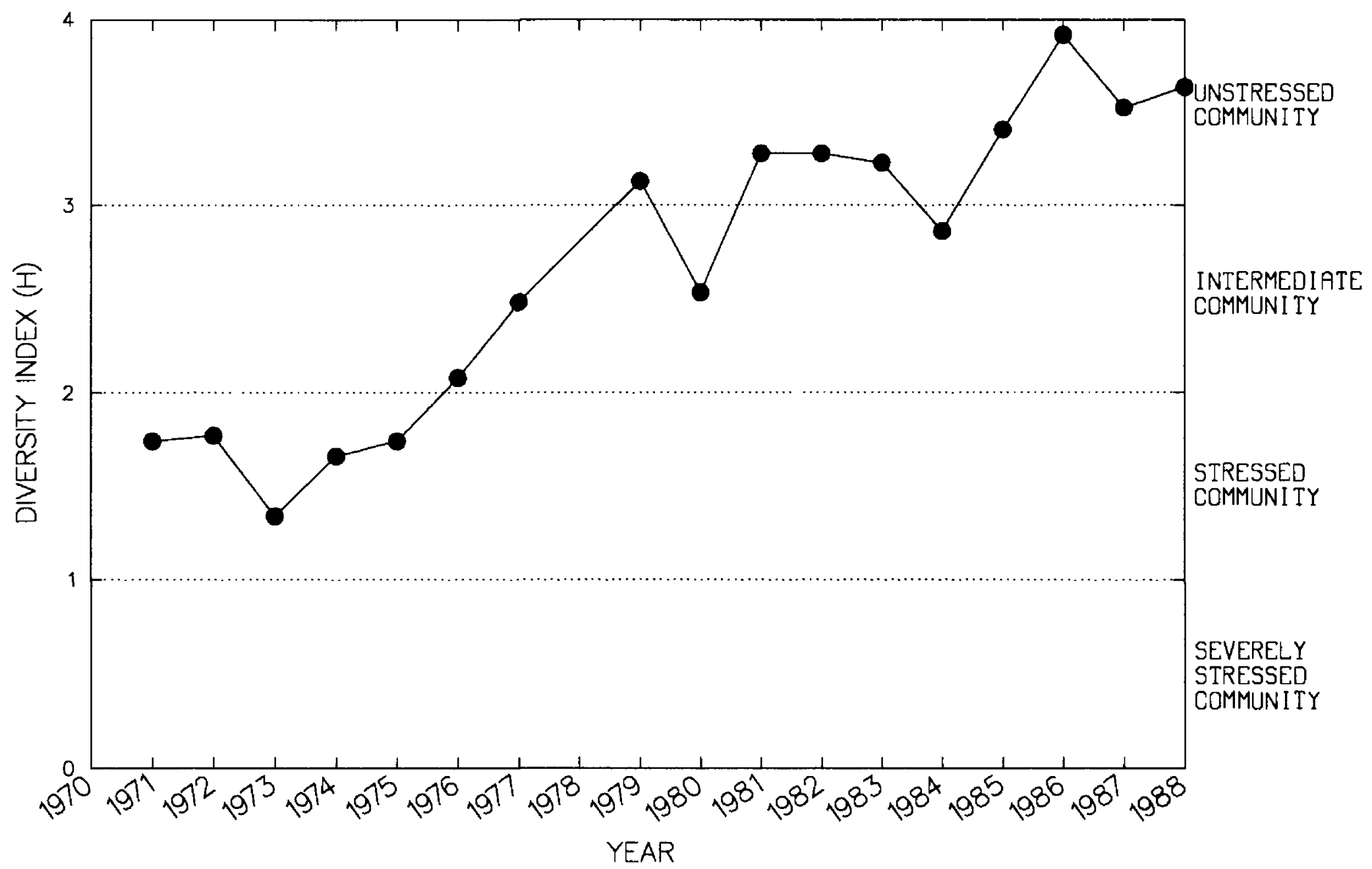


Site 42

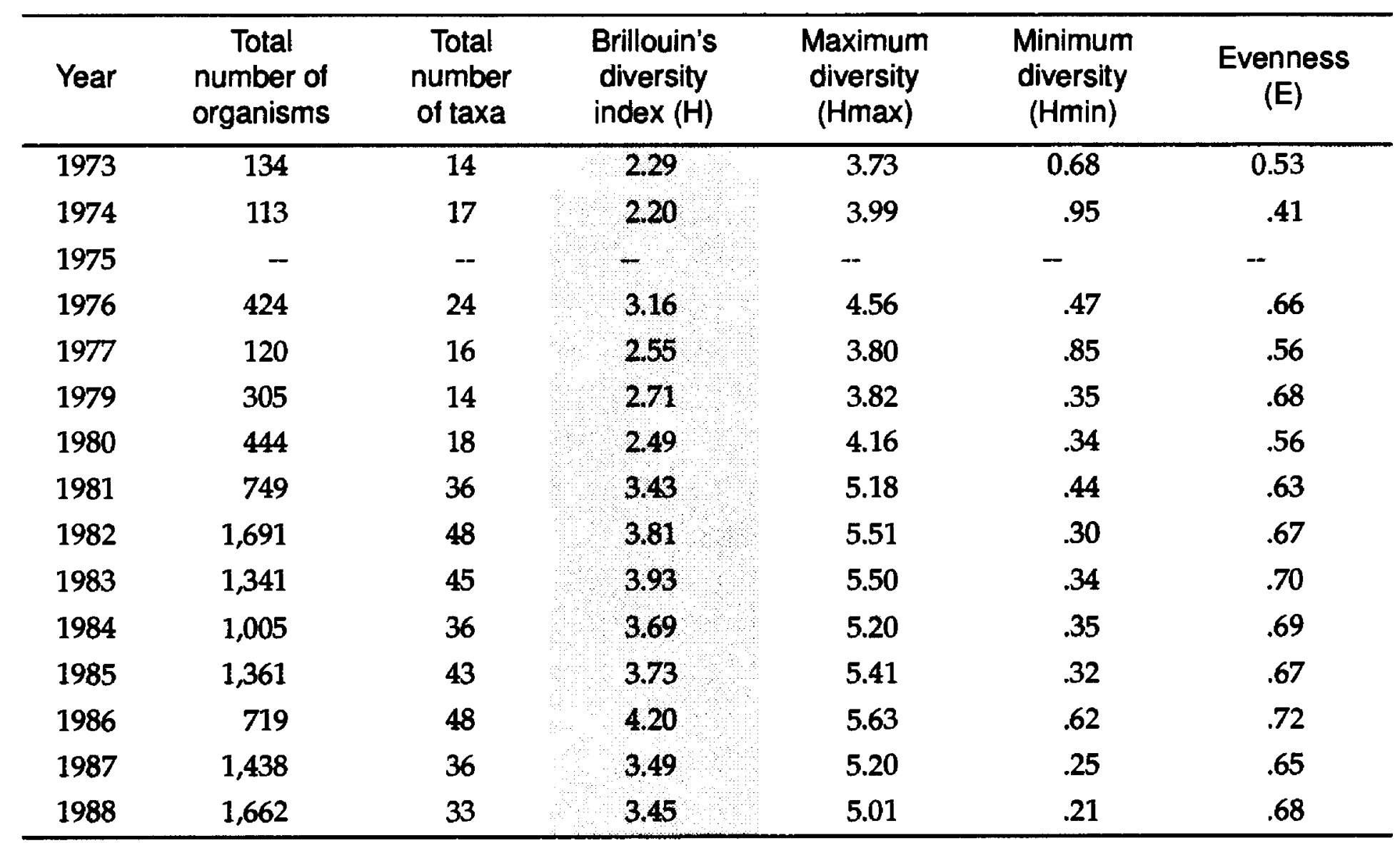

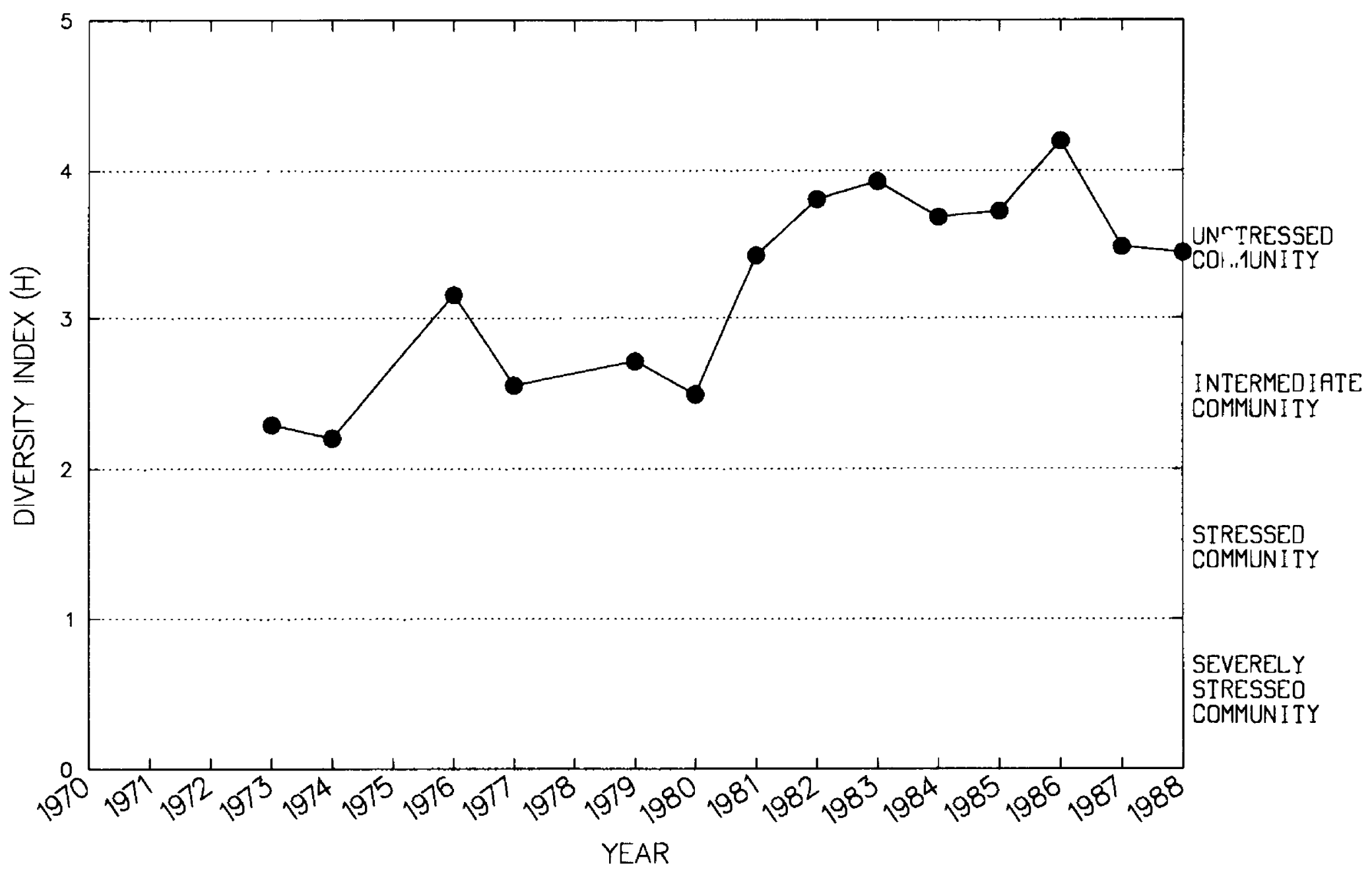

69 APPENDIX 
Site 43

\begin{tabular}{ccccccc}
\hline Year & $\begin{array}{c}\text { Total } \\
\text { number of } \\
\text { organisms }\end{array}$ & $\begin{array}{c}\text { Total } \\
\text { number } \\
\text { of taxa }\end{array}$ & $\begin{array}{c}\text { Brillouin's } \\
\text { diversity } \\
\text { index }(\mathrm{H})\end{array}$ & $\begin{array}{c}\text { Maximum } \\
\text { diversity } \\
(\mathrm{Hmax})\end{array}$ & $\begin{array}{c}\text { Minimum } \\
\text { diversity } \\
(\mathrm{Hmin})\end{array}$ & $\begin{array}{c}\text { Evenness } \\
\text { (E) }\end{array}$ \\
\hline 1973 & 191 & -8 & 1.38 & 3.04 & 0.28 & 0.40 \\
1974 & - & - & - & - & - & - \\
1975 & 228 & 8 & 1.07 & 2.98 & .24 & .30 \\
1976 & 295 & 15 & 1.95 & 3.89 & .39 & .44 \\
1977 & 12 & 6 & 1.64 & 1.90 & 1.38 & .50 \\
1979 & 130 & 10 & 1.80 & 3.11 & .48 & .50 \\
1980 & 188 & 19 & 2.75 & 4.27 & .72 & .57 \\
1981 & 298 & 22 & 2.50 & 4.39 & .58 & .50 \\
1982 & 572 & 25 & 3.24 & .4 .67 & .38 & .67 \\
\hline
\end{tabular}

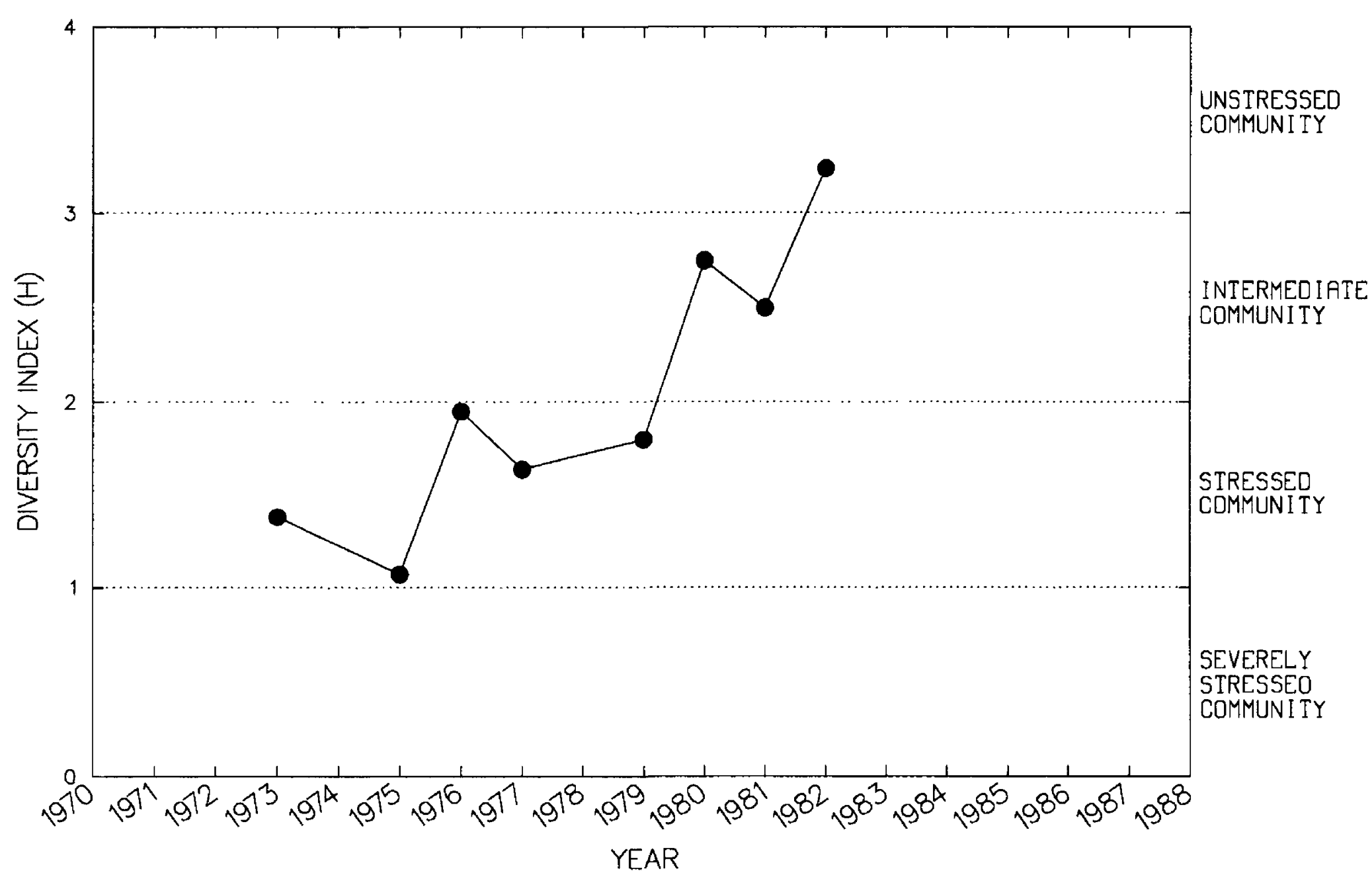


Site 44

\begin{tabular}{ccccccc}
\hline Year & $\begin{array}{c}\text { Total } \\
\text { number of } \\
\text { organisms }\end{array}$ & $\begin{array}{c}\text { Total } \\
\text { number } \\
\text { of taxa }\end{array}$ & $\begin{array}{c}\text { Brillouin's } \\
\text { diversity } \\
\text { index }(\mathrm{H})\end{array}$ & $\begin{array}{c}\text { Maximum } \\
\text { diversity } \\
\text { (Hmax) }\end{array}$ & $\begin{array}{c}\text { Minimum } \\
\text { diversity } \\
\text { (Hmin) }\end{array}$ & $\begin{array}{c}\text { Evenness } \\
(\mathrm{E})\end{array}$ \\
\hline 1973 & 770 & 16 & 1.65 & 3.94 & 0.19 & 0.39 \\
1974 & 949 & 16 & 1.66 & 3.97 & .16 & .39 \\
1975 & 997 & 18 & 2.64 & 4.14 & .17 & .62 \\
1976 & 630 & 20 & 2.50 & 4.29 & .28 & .55 \\
1977 & 433 & 18 & 2.33 & 4.04 & .34 & .54 \\
1979 & 381 & 14 & 3.21 & 3.72 & .29 & .85 \\
1980 & 1,596 & 12 & 2.91 & 3.55 & .07 & .82 \\
1981 & 2,816 & 33 & 2.29 & 5.02 & .13 & .65 \\
1982 & 1,557 & 33 & 3.23 & 4.98 & .22 & .63 \\
1983 & 1,915 & 26 & 3.25 & 4.70 & .14 & .68 \\
1984 & 1,473 & 25 & 2.96 & 4.67 & .17 & .62 \\
1985 & 2,095 & 33 & 3.27 & 5.03 & .17 & .64 \\
1986 & 1,080 & 24 & 2.96 & 4.50 & .21 & .64 \\
1987 & 2,352 & 33 & 3.16 & 5.01 & .15 & .62 \\
1988 & 2,631 & 22 & 2.65 & 4.46 & .09 & .59 \\
\hline
\end{tabular}

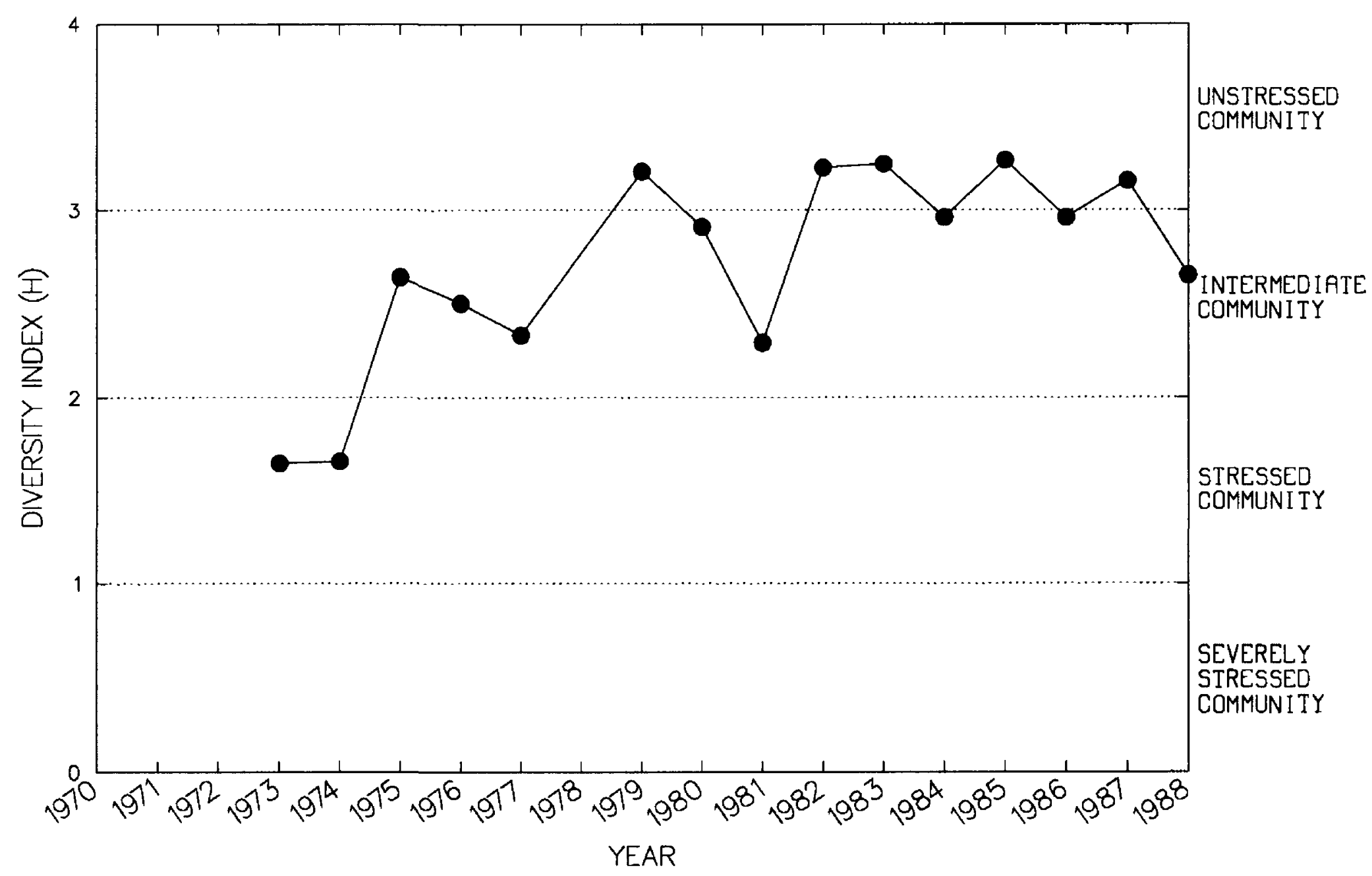


Site 45

\begin{tabular}{ccccccc}
\hline Year & $\begin{array}{c}\text { Total } \\
\text { number of } \\
\text { organisms }\end{array}$ & $\begin{array}{c}\text { Total } \\
\text { number } \\
\text { of taxa }\end{array}$ & $\begin{array}{c}\text { Brillouin's } \\
\text { diversity } \\
\text { index }(\mathrm{H})\end{array}$ & $\begin{array}{c}\text { Maximum } \\
\text { diversity } \\
\text { (Hmax) }\end{array}$ & $\begin{array}{c}\text { Minimum } \\
\text { diversity } \\
\text { (Hmin) }\end{array}$ & $\begin{array}{c}\text { Evenness } \\
(\mathrm{E})\end{array}$ \\
\hline 1973 & 15 & 7 & 1.45 & 2.22 & 1.45 & 0 \\
1974 & 147 & 7 & 1.12 & 2.67 & .29 & .35 \\
1975 & 575 & 18 & 2.48 & 4.21 & .27 & .56 \\
1976 & 836 & 22 & 2.19 & 4.36 & .24 & .47 \\
1977 & 665 & 16 & 3.00 & 3.99 & .21 & .74 \\
1979 & 150 & 15 & 2.71 & 3.64 & .67 & .69 \\
1980 & 628 & 14 & 2.86 & 3.83 & .19 & .73 \\
1981 & 1,123 & 24 & 3.30 & 4.60 & .21 & .71 \\
1982 & 1,626 & 25 & 2.93 & 4.58 & .16 & .63 \\
1983 & 1,401 & 23 & 2.93 & 4.55 & .16 & .63 \\
1984 & 1,600 & 22 & 3.11 & 4.46 & .14 & .69 \\
1985 & 980 & 20 & 2.67 & 4.24 & .19 & .61 \\
1986 & 774 & 19 & 2.92 & 4.25 & .22 & .67 \\
1987 & 1,619 & 26 & 3.00 & 4.66 & .16 & .63 \\
1988 & 1,808 & 22 & 3.30 & 4.42 & .13 & .74 \\
\hline
\end{tabular}

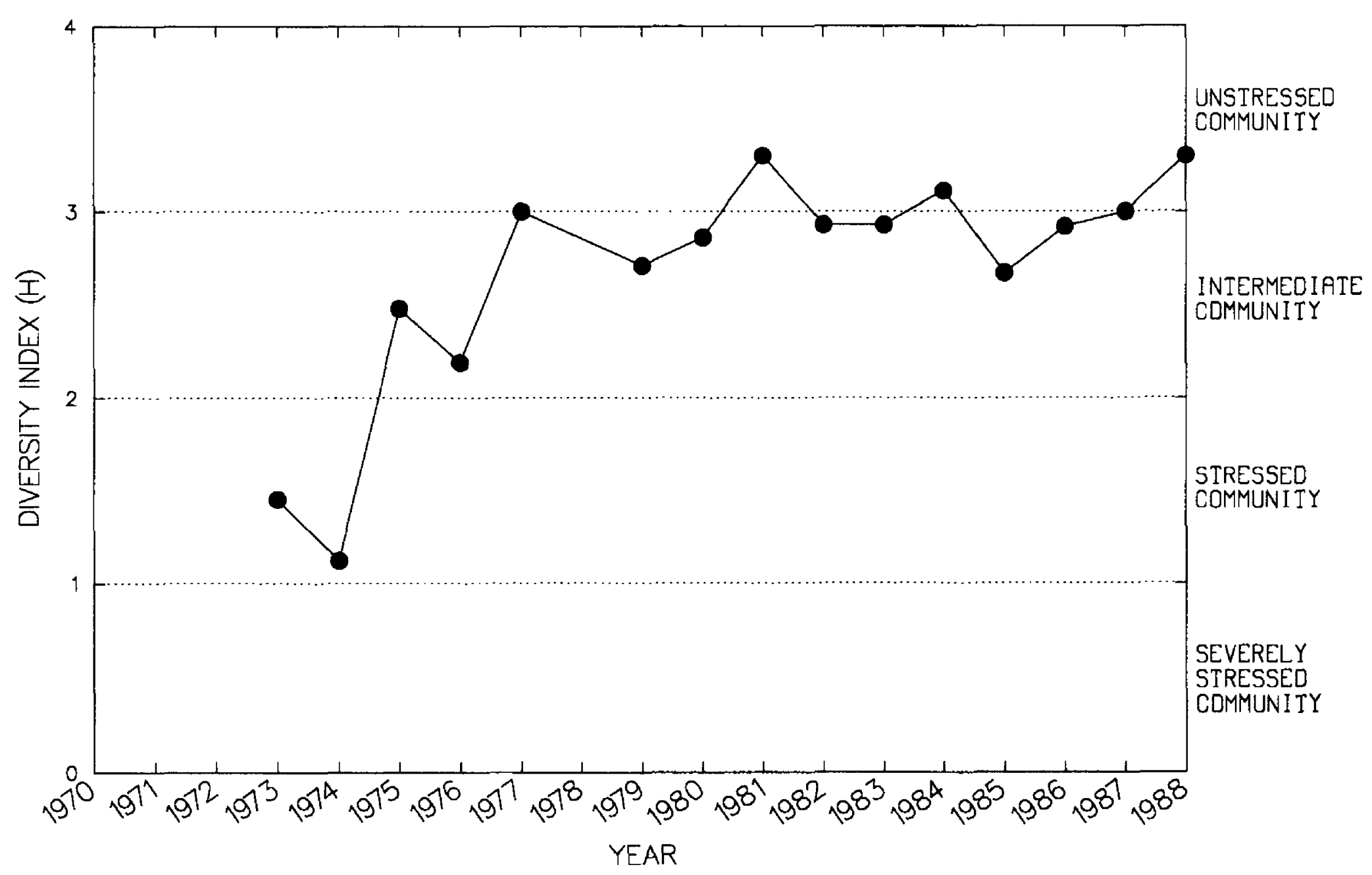


Site 46

\begin{tabular}{rcccccc}
\hline Year & $\begin{array}{c}\text { Total } \\
\text { number of } \\
\text { organisms }\end{array}$ & $\begin{array}{c}\text { Total } \\
\text { number } \\
\text { of taxa }\end{array}$ & $\begin{array}{c}\text { Brillouin's } \\
\text { diversity } \\
\text { index }(\mathrm{H})\end{array}$ & $\begin{array}{c}\text { Maximum } \\
\text { diversity } \\
\text { (Hmax) }\end{array}$ & $\begin{array}{c}\text { Minimum } \\
\text { diversity } \\
\text { (Hmin) }\end{array}$ & $\begin{array}{c}\text { Evenness } \\
(\mathrm{E})\end{array}$ \\
\hline 1973 & 346 & 8 & 0.97 & 2.95 & 0.17 & 0.29 \\
1974 & 54 & 5 & 1.56 & 2.37 & .42 & .58 \\
1975 & 790 & 16 & 1.94 & 3.97 & .18 & .46 \\
1976 & 218 & 9 & 1.20 & 3.09 & .28 & .33 \\
1977 & 795 & 18 & 1.70 & 4.11 & .21 & .38 \\
1979 & 5 & 5 & 1.38 & 1.38 & 1.38 & 1.00 \\
1980 & 420 & 10 & 2.30 & 3.24 & .19 & .69 \\
1981 & 1,022 & 19 & 2.68 & 4.26 & .18 & .61 \\
1982 & 1,642 & 16 & 2.34 & 4.00 & .10 & .57 \\
1983 & 1,853 & 17 & 1.80 & 4.05 & .09 & .43 \\
1984 & 2,266 & 21 & 2.63 & 4.41 & .10 & .59 \\
1985 & 1,090 & 21 & 3.43 & 4.42 & .18 & .77 \\
1986 & 1,771 & 23 & 2.55 & 4.47 & .13 & .56 \\
1987 & 1,645 & 25 & 2.69 & 4.66 & .16 & .56 \\
1988 & 2,065 & 24 & 3.20 & 4.54 & .12 & .70 \\
\hline
\end{tabular}

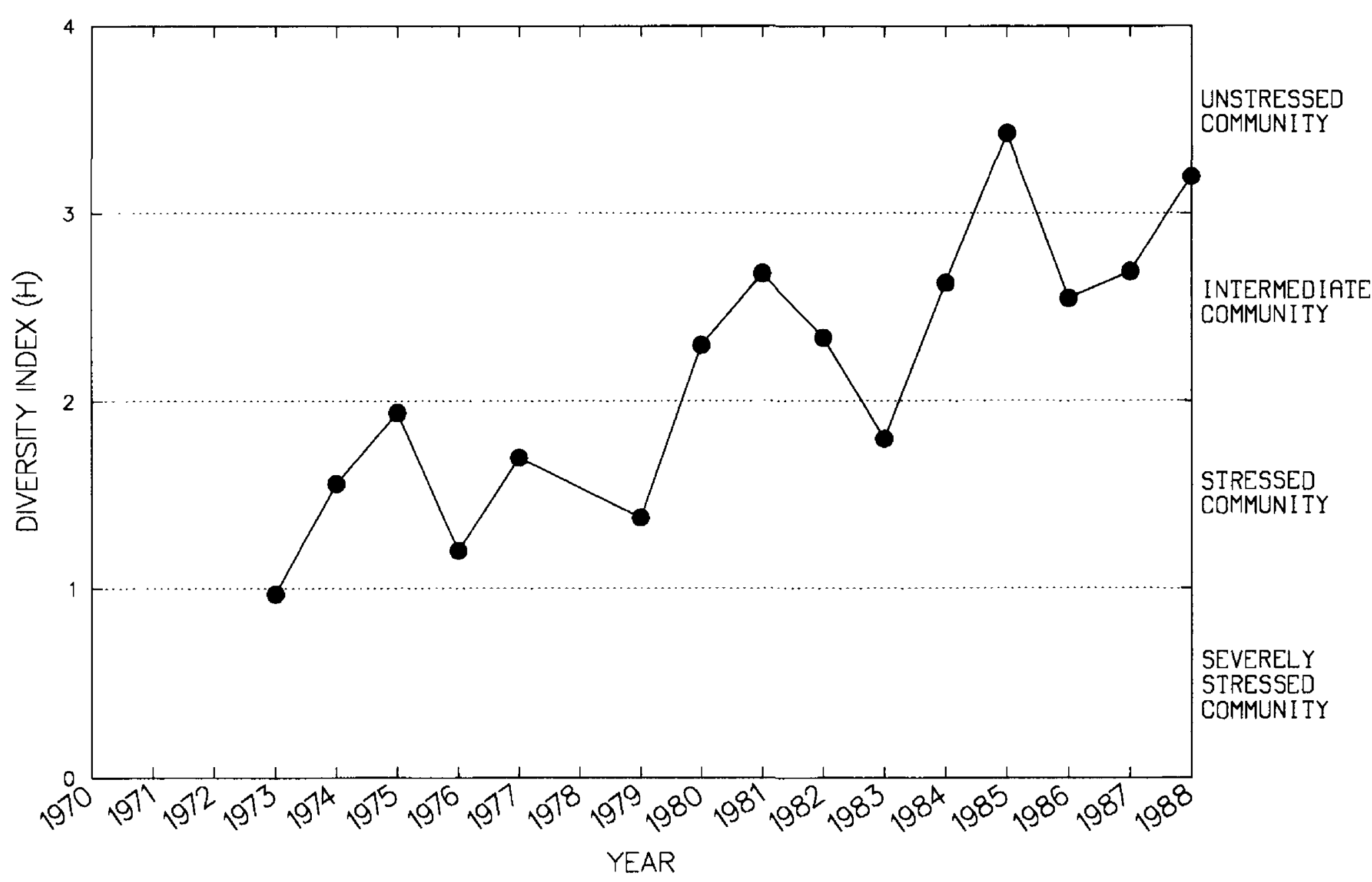


Site 47

\begin{tabular}{ccccccc}
\hline Year & $\begin{array}{c}\text { Total } \\
\text { number of } \\
\text { organisms }\end{array}$ & $\begin{array}{c}\text { Total } \\
\text { number } \\
\text { of taxa }\end{array}$ & $\begin{array}{c}\text { Brillouin's } \\
\text { diversity } \\
\text { index }(\mathrm{H})\end{array}$ & $\begin{array}{c}\text { Maximum } \\
\text { diversity } \\
(\text { Hmax })\end{array}$ & $\begin{array}{c}\text { Minimum } \\
\text { diversity } \\
(\text { Hmin) }\end{array}$ & $\begin{array}{c}\text { Evenness } \\
\text { (E) }\end{array}$ \\
\hline 1974 & 188 & 21 & 2.89 & 4.43 & 0.80 & 0.58 \\
1975 & 446 & 28 & 3.02 & 4.84 & .53 & .58 \\
1976 & 135 & 18 & 2.97 & 4.03 & .88 & .66 \\
1977 & 42 & 15 & 2.90 & 3.69 & 1.71 & .60 \\
1979 & 185 & 28 & 3.57 & 4.68 & 1.08 & .69 \\
1980 & 622 & 28 & 3.44 & 4.70 & .40 & .71 \\
1981 & 1,052 & 37 & 3.51 & 5.16 & .34 & .66 \\
1982 & 1,882 & 40 & 3.35 & 5.24 & .23 & .62 \\
1983 & 1,169 & 38 & 3.57 & 5.25 & .32 & .66 \\
1984 & 1,028 & 33 & 3.74 & 4.95 & .31 & .74 \\
1985 & 726 & 29 & 3.26 & 4.73 & .37 & .66 \\
1986 & 684 & 34 & 3.28 & 4.95 & .45 & .63 \\
1987 & 641 & 35 & 3.42 & 5.02 & .49 & .65 \\
1988 & 789 & 29 & 3.67 & 4.77 & .34 & .75 \\
\hline
\end{tabular}

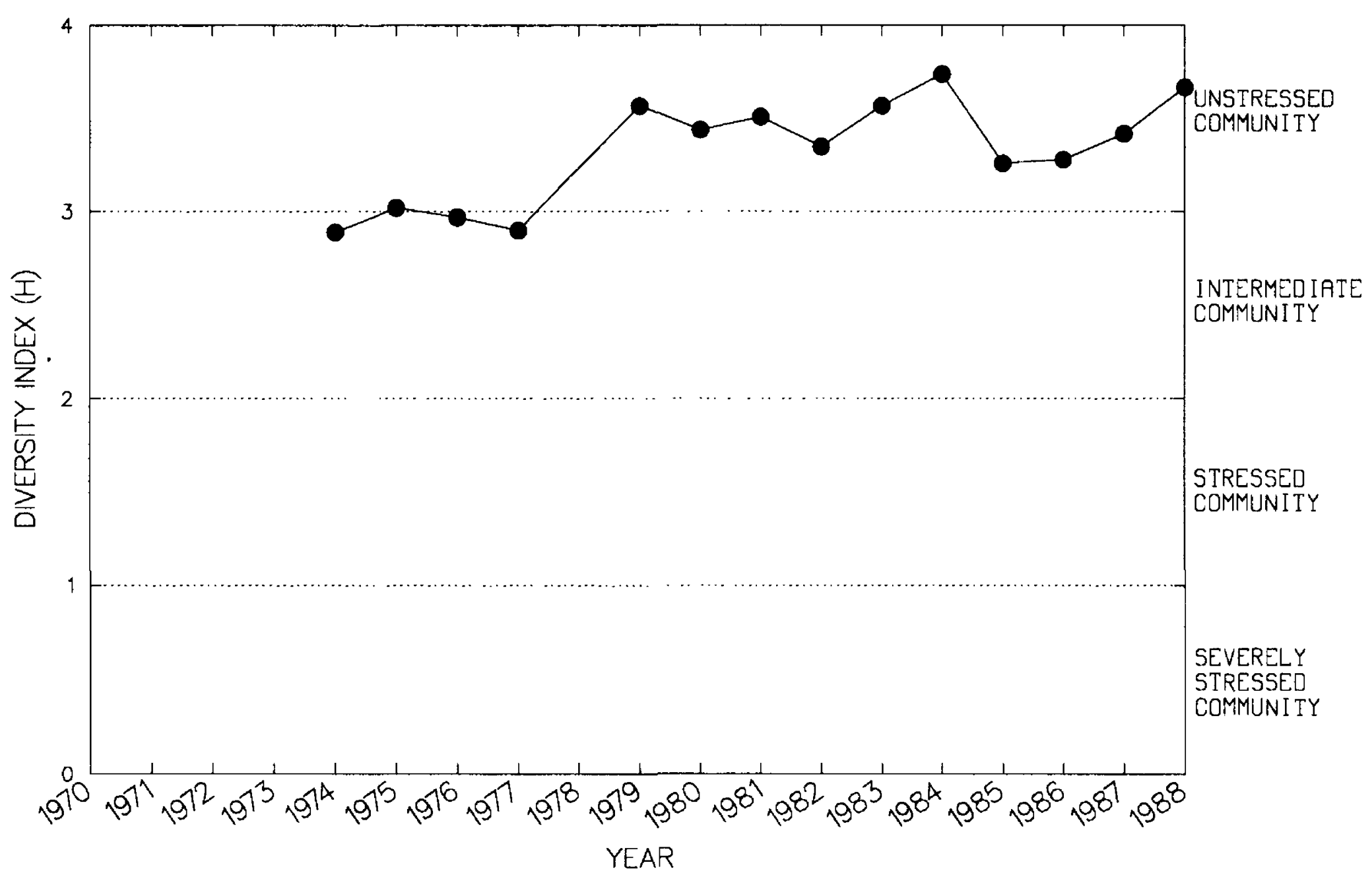


Site 48

\begin{tabular}{ccccccc}
\hline Year & $\begin{array}{c}\text { Total } \\
\text { number of } \\
\text { organisms }\end{array}$ & $\begin{array}{c}\text { Total } \\
\text { number } \\
\text { of taxa }\end{array}$ & $\begin{array}{c}\text { Brillouin's } \\
\text { diversity } \\
\text { index }(\mathrm{H})\end{array}$ & $\begin{array}{c}\text { Maximum } \\
\text { diversity } \\
\text { (Hmax) }\end{array}$ & $\begin{array}{c}\text { Minimum } \\
\text { diversity } \\
\text { (Hmin) }\end{array}$ & $\begin{array}{c}\text { Evenness } \\
(\text { E) }\end{array}$ \\
\hline 1973 & 218 & 14 & 2.59 & 3.76 & 0.46 & 0.65 \\
1974 & 188 & 17 & 2.58 & 3.86 & .64 & .60 \\
1975 & 749 & 28 & 2.89 & 4.81 & .34 & .57 \\
1976 & 518 & 23 & 3.15 & 4.48 & .38 & .67 \\
1977 & 583 & 21 & 2.88 & 4.40 & .31 & .63 \\
1979 & 166 & 21 & 2.47 & 4.41 & .88 & .45 \\
1980 & 624 & 16 & 3.10 & 3.91 & .22 & .78 \\
1981 & 1,307 & 43 & 4.10 & 5.37 & .33 & .75 \\
1982 & 2,525 & 35 & 3.21 & 5.08 & .15 & .62 \\
$1983^{1}$ & 733 & 32 & 3.61 & 5.03 & .40 & .69 \\
1984 & 1,648 & 24 & 3.04 & 4.58 & .15 & .65 \\
$1985^{1}$ & 684 & 28 & 3.43 & 4.75 & .37 & .70 \\
$1986^{1}$ & 604 & 28 & 3.62 & 4.77 & .41 & .74 \\
1987 & 1,139 & 31 & 3.15 & 4.96 & .27 & .61 \\
1988 & 1,985 & 32 & 3.43 & 4.94 & .17 & .68 \\
\hline
\end{tabular}

${ }^{1}$ Sampled upstream riffle because of bridge construction.

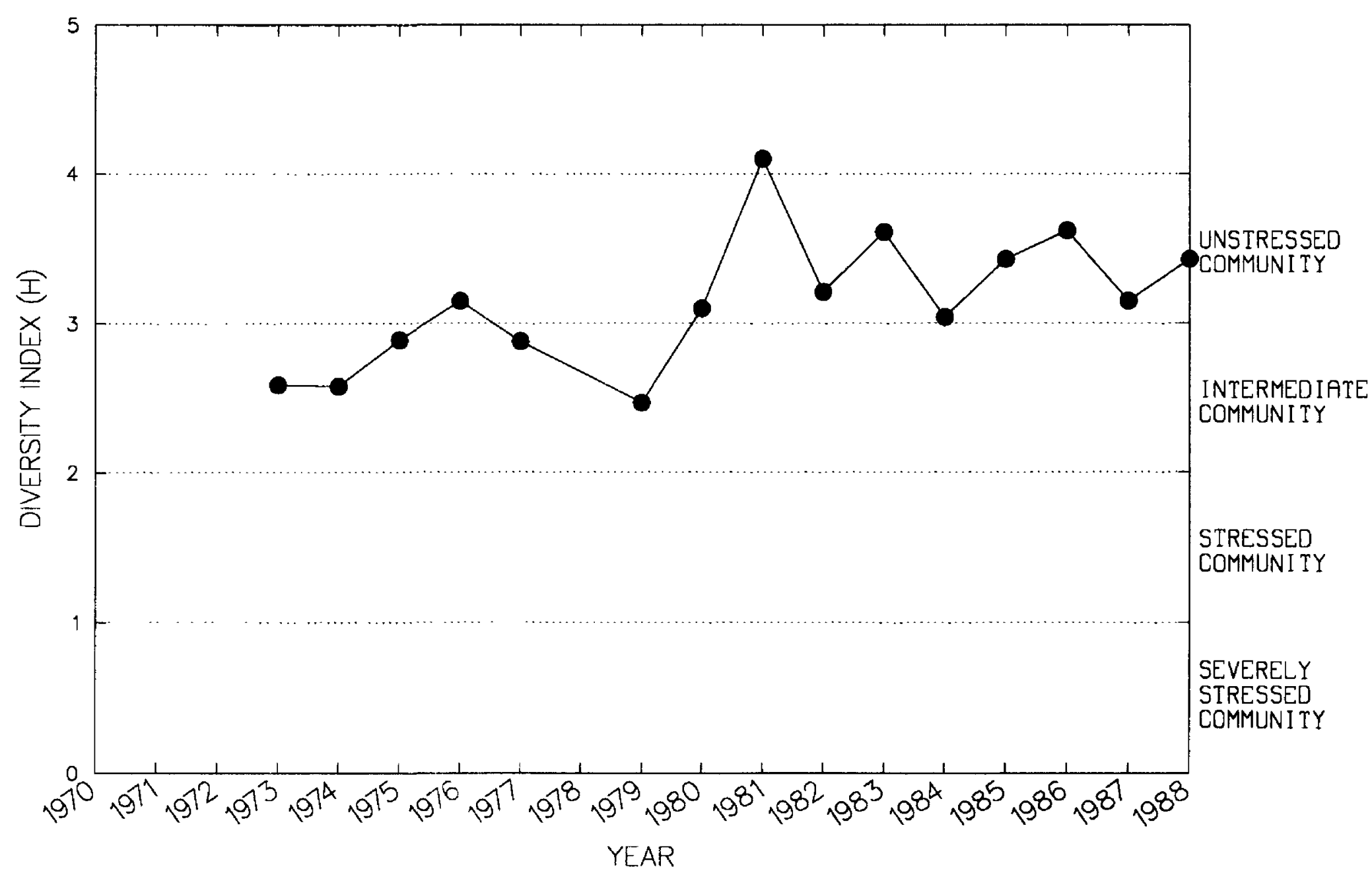


Site 49

\begin{tabular}{ccccccc}
\hline Year & $\begin{array}{c}\text { Total } \\
\text { number of } \\
\text { organisms }\end{array}$ & $\begin{array}{c}\text { Total } \\
\text { number } \\
\text { of taxa }\end{array}$ & $\begin{array}{c}\text { Brillouin's } \\
\text { diversity } \\
\text { index }(\mathrm{H})\end{array}$ & $\begin{array}{c}\text { Maximum } \\
\text { diversity } \\
\text { (Hmax) }\end{array}$ & $\begin{array}{c}\text { Minimum } \\
\text { diversity } \\
\text { (Hmin) }\end{array}$ & $\begin{array}{c}\text { Evenness } \\
\text { (E) }\end{array}$ \\
\hline 1973 & 29 & 2 & 0.17 & 1.04 & 0.17 & 0 \\
1974 & 0 & 0 & 0 & 0 & 0 & 0 \\
1975 & 988 & 12 & 2.54 & 3.56 & .11 & .70 \\
1976 & 449 & 12 & 2.59 & 3.55 & .22 & .71 \\
1977 & 279 & 13 & 2.18 & 3.65 & .35 & .56 \\
1979 & 222 & 14 & 2.28 & 3.84 & .45 & .54 \\
1980 & 1,983 & 15 & 2.26 & 3.88 & .08 & .57 \\
1981 & 2,907 & 20 & 2.70 & 4.31 & .08 & .62 \\
1982 & 2,442 & 21 & 2.76 & 4.37 & .09 & .62 \\
1983 & 1,227 & 18 & 2.66 & 4.13 & .14 & .63 \\
1984 & 1,211 & 17 & 2.65 & 4.05 & .14 & .64 \\
1985 & 548 & 20 & 2.82 & 4.27 & .31 & .63 \\
1986 & 1,093 & 17 & 3.10 & 4.05 & .15 & .75 \\
1987 & 1,357 & 15 & 3.06 & 3.89 & .11 & .78 \\
1988 & 1,373 & 20 & 3.17 & 4.32 & .14 & .73 \\
\hline
\end{tabular}

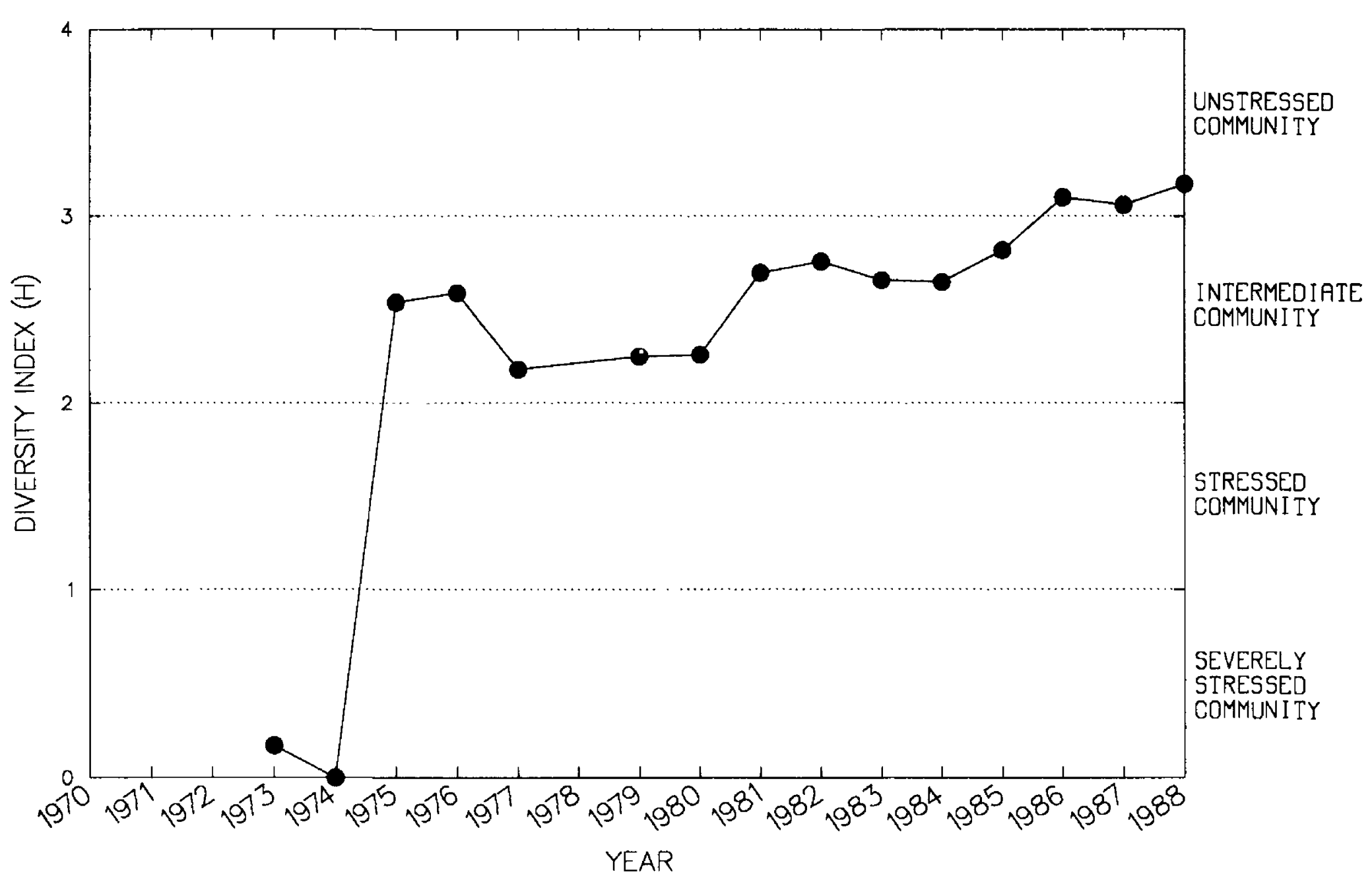


Site $\mathbf{5 0}$

\begin{tabular}{ccccccc}
\hline Year & $\begin{array}{c}\text { Total } \\
\text { number of } \\
\text { organisms }\end{array}$ & $\begin{array}{c}\text { Total } \\
\text { number } \\
\text { of taxa }\end{array}$ & $\begin{array}{c}\text { Brillouin's } \\
\text { diversity } \\
\text { index }(H)\end{array}$ & $\begin{array}{c}\text { Maximum } \\
\text { diversity } \\
\text { (Hmax) }\end{array}$ & $\begin{array}{c}\text { Minimum } \\
\text { diversity } \\
\text { (Hmin) }\end{array}$ & $\begin{array}{c}\text { Evenness } \\
\text { (E) }\end{array}$ \\
\hline 1973 & 25 & 2 & 0.19 & 1.04 & 0.19 & 0 \\
1974 & 153 & 8 & 1.42 & 2.88 & .33 & .43 \\
1975 & 534 & 10 & 1.89 & 3.30 & .15 & .55 \\
1976 & 849 & 14 & 1.73 & 3.81 & .15 & .43 \\
1977 & 1,003 & 13 & 1.65 & 3.66 & .12 & .43 \\
1979 & 263 & 9 & 1.98 & 3.10 & .24 & .61 \\
1980 & 1,412 & 12 & 2.64 & 3.59 & .08 & .73 \\
1981 & 2,201 & 20 & 2.51 & 4.29 & .10 & .58 \\
1982 & 3,155 & 20 & 2.67 & 4.33 & .07 & .61 \\
1983 & 1,744 & 16 & 2.66 & 3.96 & .09 & .66 \\
1984 & 2,058 & 21 & 2.68 & 4.35 & .11 & .61 \\
1985 & 1,362 & 19 & 2.77 & 4.25 & .14 & .64 \\
1986 & 1,824 & 19 & 2.77 & 4.20 & .11 & .65 \\
1987 & 1,623 & 22 & 3.13 & 4.47 & .14 & .69 \\
1988 & 2,277 & 15 & 2.78 & 3.92 & .07 & .71 \\
\hline
\end{tabular}

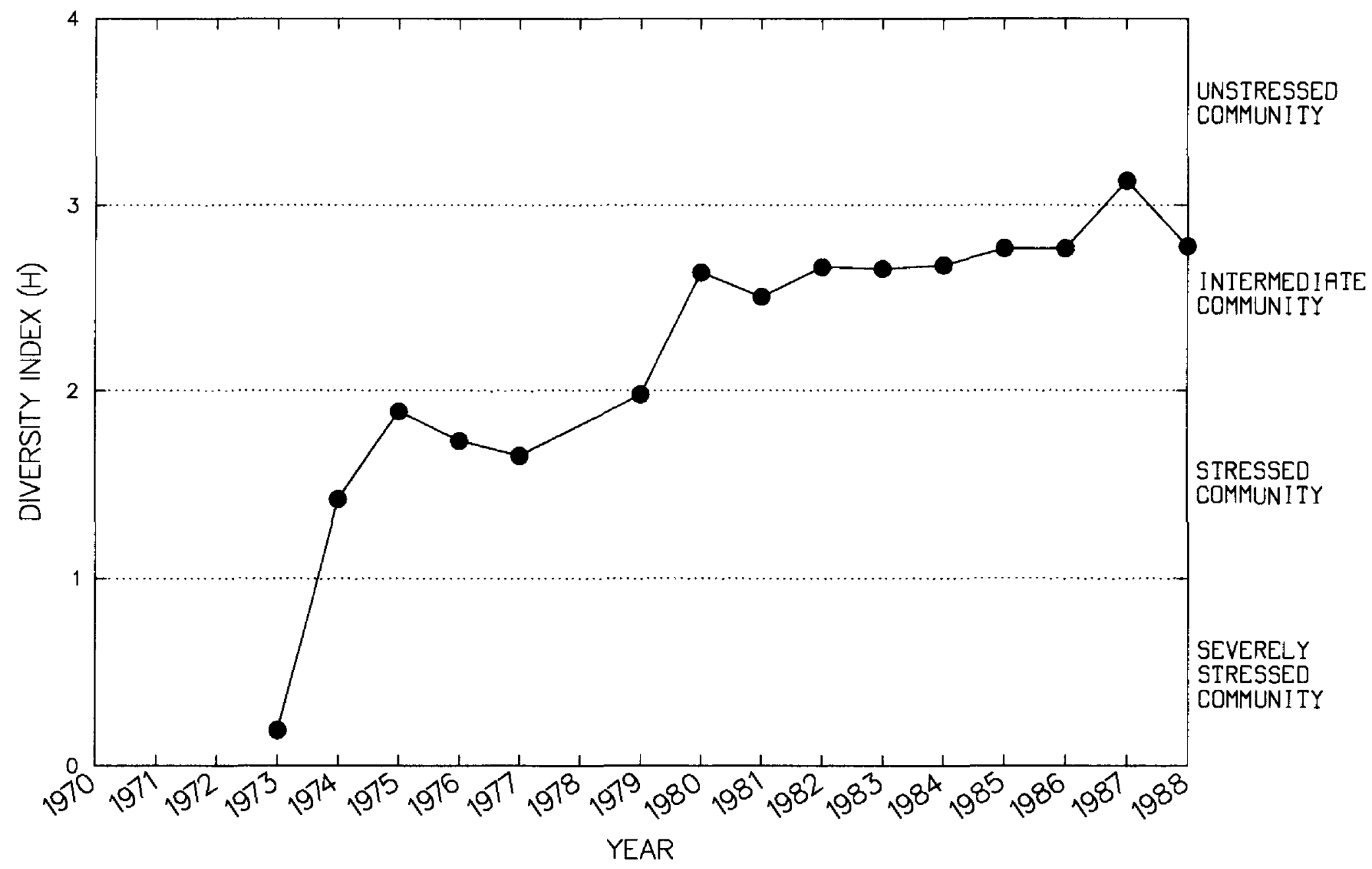


Site 51

\begin{tabular}{ccccccc}
\hline Year & $\begin{array}{c}\text { Total } \\
\text { number of } \\
\text { organisms }\end{array}$ & $\begin{array}{c}\text { Total } \\
\text { number } \\
\text { of taxa }\end{array}$ & $\begin{array}{c}\text { Brillouin's } \\
\text { diversity } \\
\text { index }(H)\end{array}$ & $\begin{array}{c}\text { Maximum } \\
\text { diversity } \\
\text { (Hmax) }\end{array}$ & $\begin{array}{c}\text { Minimum } \\
\text { diversity } \\
\text { (Hmin) }\end{array}$ & $\begin{array}{c}\text { Evenness } \\
\text { (E) }\end{array}$ \\
\hline 1983 & 2,889 & 22 & 2.41 & 4.44 & 0.08 & 0.53 \\
1984 & 2,879 & 22 & 2.81 & 4.47 & .08 & .62 \\
1985 & 4,264 & 19 & 2.18 & 4.24 & .05 & .51 \\
1986 & 1,520 & 23 & 2.39 & 4.47 & .15 & .52 \\
1987 & 12,157 & 20 & 1.75 & 4.33 & .02 & .40 \\
1988 & 3,921 & 17 & 2.58 & 4.09 & .05 & .63 \\
\hline
\end{tabular}

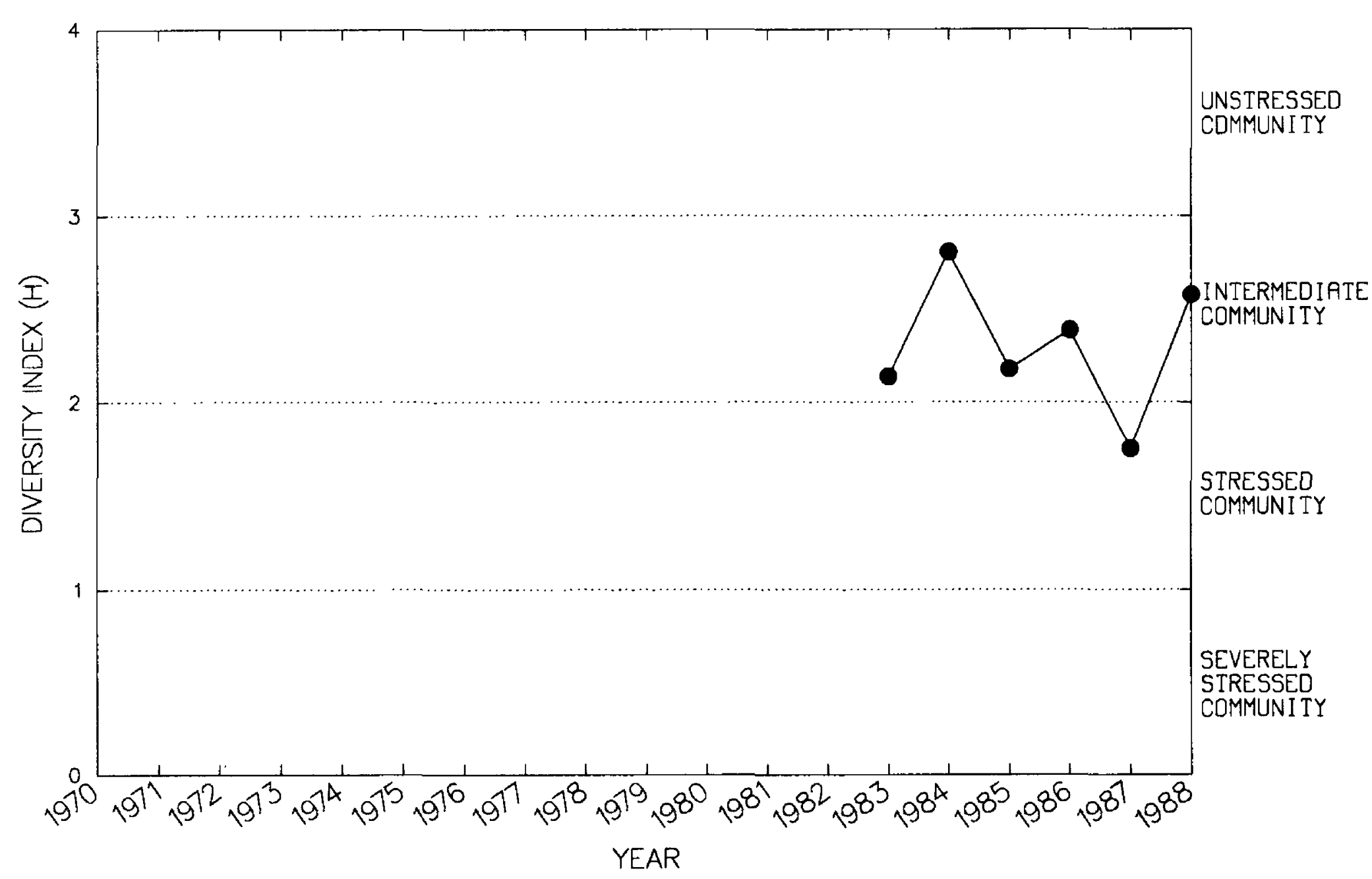

